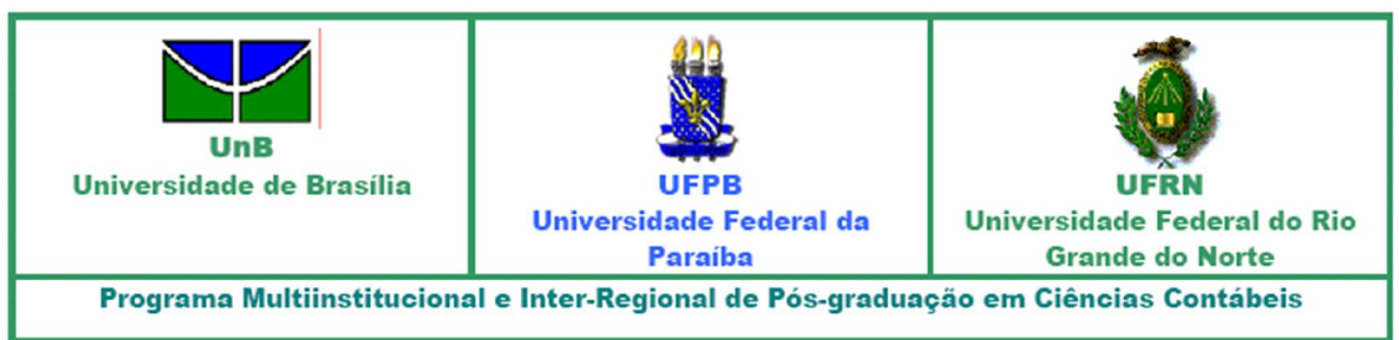

UNIVERSIDADE DE BRASÍLIA

UNIVERSIDADE FEDERAL DA PARAÍBA

UNIVERSIDADE FEDERAL DO RIO GRANDE DO NORTE

PROGRAMA MULTIINSTITUCIONAL E INTER-REGIONAL DE

PÓS-GRADUAÇÃO EM CIÊNCIAS CONTÁBEIS

ADRIANA ISABEL BACKES STEPPAN

UMA ANÁLISE DA INFLUÊNCIA DO VIÉS DE OTIMISMO NO JULGAMENTO

DE PROBABILIDADES DE ATIVOS E PASSIVOS CONTINGENTES

NATAL/RN

2016 

DE PROBABILIDADES DE ATIVOS E PASSIVOS CONTINGENTES

Tese apresentada ao Programa MultiInstitucional e Inter-Regional de Pós-Graduação em Ciências Contábeis da Universidade de Brasília, Universidade Federal da Paraíba e Universidade Federal do Rio Grande do Norte, como requisito parcial à obtenção do título de Doutora em Ciências Contábeis.

Orientador: Dr. César Augusto Tibúrcio Silva

Area de Concentração: Mensuração Contábil

Linha de Pesquisa: Contabilidade para Tomada de Decisão 
Backes Steppan, Adriana Isabel.

Uma análise da influência do viés de otimismo no julgamento de probabilidades de ativos e passivos contingentes / Adriana Isabel Backes Steppan; orientador Dr. César Augusto Tibúrcio Silva. Brasília, 2016.

$128 \mathrm{p}$.

Tese (Doutorado em Ciências Contábeis) - Universidade de Brasília. Programa Multi-institucional e Inter-Regional de PósGraduação em Ciências Contábeis UnB/UFPB/UFRN, 2016.

1. Viés Otimista. 2. Eventos Contingentes. 3. Quase-Experimento. 4. Profissionais Contábeis. I. Silva, César Augusto Tibúrcio. II. Título. 


\section{UMA ANÁLISE DA INFLUÊNCIA DO VIÉS DE OTIMISMO NO JULGAMENTO DE PROBABILIDADES DE ATIVOS E PASSIVOS CONTINGENTES}

Tese apresentada ao Programa Multi-Institucional e Interegional de Pós-Graduação em Ciências Contábeis UnB/UFPB/UFRN como requisito parcial à obtenção do título de doutora em Ciências Contábeis.

Aprovada em 28 de abril de 2016.

Prof. Dr. CÉSAR AUGUSTO TIBÚRCIO SILVA

Universidade de Brasília - UnB

Orientador

Prof. Dr. JOSÉ DIONÍSIO GOMES DA SILVA

Universidade Federal do Rio Grande do Norte - UFRN

Membro Examinador Interno

Prof. Dr. ADILSON DE LIMA TAVARES

Universidade Federal do Rio Grande do Norte - UFRN

Membro Examinador Interno

Prof. Dr. LUIZ PAULO FÁVERO

Universidade de São Paulo - USP

Membro Examinador Externo

Prof. Dr. LUCAS AYRES BARREIRA DE CAMPOS BARROS

Universidade de São Paulo - USP

Membro Examinador Externo 
À minha família, em especial Ao meu marido Thomas. Vocês são especiais! Amo de todo coração! 


\section{AGRADECIMENTOS}

Ser grato é uma das atitudes mais nobres que um ser humano pode ter! Nesse sentido, elevo-me a Deus por permitir a vida, agradecer pelas infinitas graças recebidas durante o processo, as forças que brotam nos momentos mais adversos, a coragem, a saúde e tantos outros sentimentos!

Sem querer transformar a gratidão em uma escala de importância, mas sim de evidenciar a intensidade devida a todos os que permitiram e estiverem presentes nessa caminhada, penso primeiramente no Thô, pela paciência e compreensão, na minha família que mesmo distante se manteve sempre próxima, acompanhando-me em todas as etapas! Tanize, você foi especial!!

Meus agradecimentos ao professor César Augusto Tibúrcio Silva! Sua dedicação foi muito além da orientação! Tive a oportunidade de conhecer um ser humano incrível que você é, que se manteve sempre disposto a me ouvir, compreender e orientar! Com simplicidade, transmitia seus conhecimentos e, dessa forma, as minhas dúvidas eram dirimidas. Muito obrigada!

Pela contribuição do Programa Multiinstitucional e Inter-regional de Pós-Graduação em Ciências Contábeis UnB, UFPB e UFRN, por ter oportunizado um ambiente para a disseminação do conhecimento contábil. Um agradecimento a todos os professores das disciplinas cursadas: Prof. Dr. César Augusto Tibúrcio Silva; Prof. Dr. Edilson Paulo; Prof. Dr. Jorge Katsumi Niyama; Prof. Dr. José Dionísio Gomes da Silva; Prof. Dr. Ivan Gartner; Prof. Dr. José Matias Pereira; Prof. Otávio Ribeiro de Medeiros; Ph.D., Prof. Dr.Paulo Roberto Barbosa Lustosa, Dr. Paulo Roberto Nóbrega Cavalcante e Anderson Mól.

À Universidade Federal do Rio Grande do Norte, meu eterno agradecimento, a começar pelo Departamento de Ciências Contábeis, em especial ao professor Mascarenhas pelo incentivo, todos os funcionários da coordenação e a todos os meus colegas que permitiram meu afastamento durante todo o processo de doutoramento. À pró reitoria de pósgraduação, pelo auxílio financeiro, em especial à professora Edna Maria da Silva e Maria Lassalete da Costa Cruz. Aos professores Adilson e Erivan, os quais, na representação da coordenação regional do programa multi, sempre se mostraram disponíveis para ajudar no que fosse necessário.

Ao G5, minha turma do doutorado... para vocês só uma frase... "sinto saudades do que vivemos juntos”! Márcia, Gilmara, Josicarla, Lidiane, Diego, Daniel, Mateus, Luiz, Lucio e Leonardo vocês todos são especiais, cada um com suas características individuais, mas que 
deixaram suas marcas. Tivemos a amiga conselheira da turma, o brincalhão, o ranzinza motorista da rodada... querido Lúcio sempre disponível para nos ajudar rsrsr! Nossos momentos "bem tensos" também nos proporcionaram muitas alegrias e, penso eu que a Amizade é a "cara" da nossa turma!

Contudo, não poderia deixar de externar um agradecimento de uma forma muito carinhosa ao Luiz, que me ajudou no processo da coleta dos dados, ao Diego, um amigo incrível, pessoa maravilhosa que tive a oportunidade de conhecer, parceiro nos estudos além de professor particular das minhas dúvidas de estatística. Apesar da distância, tenho a certeza de que nossa amizade permanecerá! À Josi, outra pessoa com quem tive a oportunidade de aprender. O doutorado, por várias razões, permitiu a nossa proximidade e, consequentemente, a constituição de uma linda amizade que perdura. Certamente, Josi, você é a pessoa mais presente na minha caminhada, esteve do meu lado em todos os momentos, os difíceis e os alegres, o que a torna especial!

Aos meus amigos, um agradecimento para lá de especial! Sem eles certamente tudo seria muito mais difícil e mais penoso. Para os que estão próximos, ainda bem que compreenderam a ausência dos vários encontros os quais levei falta, aos distantes, porém, importantes em minha vida, graças à tecnologia foi possível fazer os desabafos e escutar palavras de apoio e incentivo nos momentos em que era exatamente isso que eu precisava ouvir!!

Ao Conselho Regional de Contabilidade do RN, em especial à professora Lieda e Jacinta, muitíssimo obrigada pela colaboração no processo de formação da amostra para garantir o sucesso dessa pesquisa. Sem a ajuda desse conselho, certamente o trabalho seria mais árduo.

Um agradecimento aos profissionais que contribuíram com o desenvolvimento da pesquisa. A contribuição foi extremamente valorosa, por se tratar de vários encontros e para os quais a presença era indispensável.

Aos professores, membros da Banca Examinadora, Dr. João Cláudio Todorov, Dr. Diogo Henrique Silva de Lima, Dr. Adilson de Lima Tavares, Dr. José Dionísio Gomes da Silva, Dr. Luiz Paulo Fávero e Lucas Ayres Barreira de Campos Barros pela disponibilidade de tempo para as leituras, contribuições e participação da banca. A vocês, muito obrigada! 
"Por vezes sentimos que aquilo que fazemos não é senão uma gota de água no mar. Mas o mar seria menor se lhe faltasse uma gota". (Madre Teresa de Calcutá). 


\section{RESUMO}

Esta tese teve como objetivo principal analisar os efeitos do viés emocional do otimismo exagerado no julgamento do profissional contábil, nas avaliações das probabilidades de ocorrência de ativos e passivos contingentes. Esse estudo refere-se a um quase-experimento, tendo como técnica de coleta de dados um questionário organizado em duas partes (a primeira refere-se ao instrumento de medição do viés otimista e dos fatores moderadores e a segunda parte trata dos cenários para os quais o indivíduo fez julgamento de probabilidades). $\mathrm{O}$ instrumento foi aplicado de forma presencial e em quatro encontros sequenciais. Do total da amostra, optou-se por elaborar a análise a partir dos dados extremos, um grupo com a presença máxima do viés otimista e outro sem a presença do mesmo, os quais correspondem ao primeiro e último tercil, totalizando 87 profissionais da área contábil. Pelos resultados alcançados, constatou-se a presença do viés otimista em 44 indivíduos ao passo que, para 43 participantes, não houve a presença dele. Com base na análise das estimativas indicadas pelos participantes excessivamente otimistas, foi possível verificar o efeito do viés na avaliação das estimativas. Ao se fazer a regressão entre as avaliações de probabilidades de ocorrências de ativos e passivos contingentes com as variáveis independentes ora representadas pelo perfil do viés otimista e fatores moderadores de eventos como o controle e experiência prévia, foi constatada essa relação. No que diz respeito a esses fatores moderadores foi possível confirmar as relações entre eles e o viés otimista. Ao se estabelecer uma análise do julgamento de probabilidades dos seis cenários apresentados, os achados mostraram que os indivíduos com a presença do viés otimista efetuaram julgamentos de probabilidades com expectativas abaixo ou igual a 50\% para o cenário 1 (passivo) e 2 e 6 (ativos), contudo, para os cenários 3 (passivo), 4 (ativo) e 5 (passivo) os achados da pesquisa revelam que os indivíduos com a presença do viés apresentaram um julgamento de probabilidade com expectativas acima de $50 \%$. Ao se examinar o contexto geral desta pesquisa, pode-se dizer que o viés otimista ajuda a explicar as avaliações das estimativas de probabilidades dos eventos, entretanto, observa-se que nem sempre os impactos aconteceram da forma prevista pelas teorias que embasam o viés otimista. Para os cenários ativos eram esperadas estimativas com probabilidades superiores a 50\%, no entanto, se confirmou, desse modo, apenas para o evento 4. Para os cenários passivos eram aguardados julgamentos de probabilidades inferiores a $50 \%$, contudo, apenas para o cenário 1 , esse fato se confirmou.

Palavras-chave: Viés Otimista. Eventos Contingentes. Quase-Experimento. Profissionais Contábeis. 


\begin{abstract}
This thesis aimed to analyze the effects of exaggerated optimism emotional bias in the accounting professional judging, in the assessments of the probability of occurrence of contingent assets and liabilities. This study refers to a quasi-experiment, with the data collection technique an organized questionnaire into two parts (the first refers to the measurement instrument of optimistic bias and the moderating factors, and the second part deals with scenarios for which the individual has made judgements of probabilities). The instrument was applied in four sequential meeting session. From the total sample, it was decided to prepare the analysis from extreme data, a group with the highest presence of optimistic bias and the other without the presence of the same, which correspond to the first and last tertile, totaling 87 professionals in the accounting area. From the results achieved, there was the presence of optimistic bias in 44 individuals whereas 43 participants not. Based on the analysis of the estimates indicated by overly optimistic participants, it was possible to verify the effect of bias in the evaluation of the estimates. The regression between assessments of probabilities of occurrences of contingent assets and liabilities with the independent variables now represented by the optimistic bias profile and event moderating factors, such as the control and previous experience, it was found that relationship. With regard to these moderating factors it was possible to confirm the relationship between them and the optimistic bias. By establishing an analysis of the judgment probabilities of the six scenarios presented, the findings showed that individuals with the presence of optimistic bias did probabilities judgement with expectations below or equal to $50 \%$ for scenario 1 (passive) and scenarios 2 and 6 (assets), however, for scenarios 3 (liabilities), 4 (assets), and 5 (liabilities), the research findings reveal that individuals with the presence of bias had a judgement of probability above 50\% expectations. When examining the general context of this research, it can be said that the optimistic bias helps explain the assessments of estimates of probabilities of the events, however, it is observed that not always the impacts happened as expected by the theories that support the optimistic bias. For assets scenarios were expected estimates with probabilities above $50 \%$, however, it was confirmed thus only to event four. For liabilities scenarios were expected judgments of probability less to $50 \%$, however, only for scenario 1 , this fact was confirmed.
\end{abstract}

Keywords: Optimistic bias. Contingent events. Quasi-Experiment. Accounting professionals. 


\section{LISTA DE TABELAS}

Tabela 01 - Comparação entre a amostra total e a amostra reduzida ..............................58

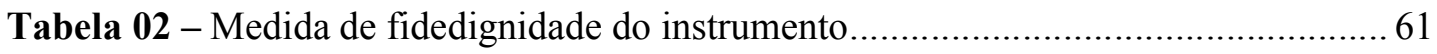

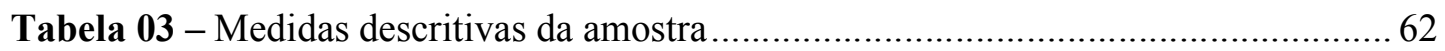

Tabela 04 - Regressão Linear Múltipla variável dependente: Ativo...................................64

Tabela 05 - Regressão Linear Múltipla do Ativo com stepwise ......................................65

Tabela 06 - Regressão Linear Múltipla variável dependente: Passivo...............................66 66

Tabela 07 - Regressão Linear Múltipla do Passivo com stepwise .....................................66

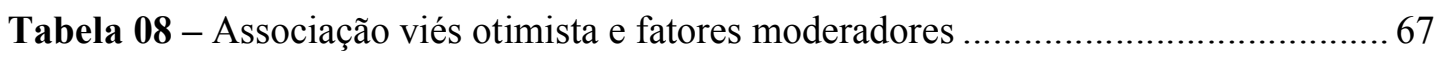

Tabela 09 - Medida de associação entre o perfil EO e os cenários..................................... 70 


\section{LISTA DE QUADROS}

Quadro 01 - Viés Otimista e Otimismo Disposicional ................................................. 30

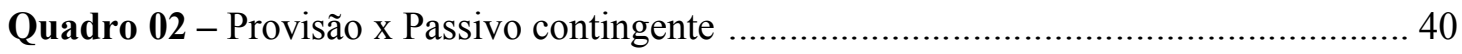

Quadro 03 - Divulgação de informações de provisões ..................................................... 41

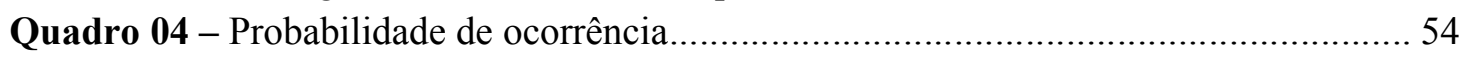




\section{LISTA DE FIGURAS}

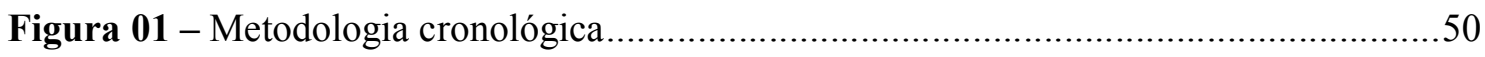

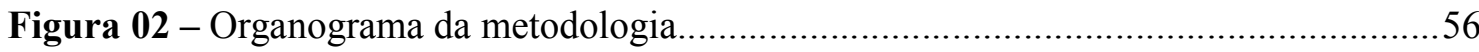




\section{LISTA DE ABREVIATURAS E SIGLAS}

CPC - Comitê de Pronunciamentos Contábeis

CRC - Conselho Regional de Contabilidade

EO - Excesso de Otimismo

EGA- Extreme Group Approach

IASB - International Accounting Standards Board

IFRS- International Financial Reporting Standards 


\section{SUMÁRIO}

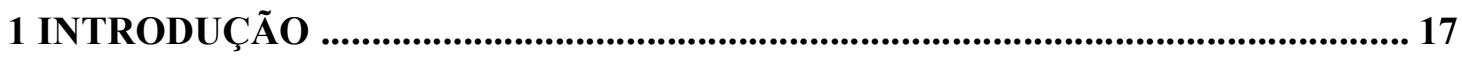

1.1 CONTEXTUALIZAÇÃO DO PROBLEMA E JUSTIFICATIVA .............................. 17

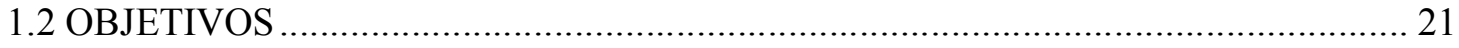

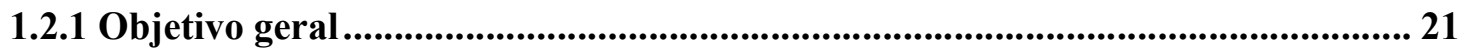

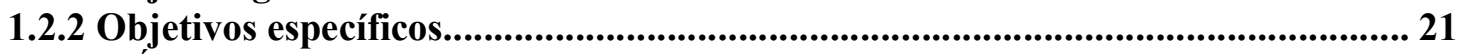

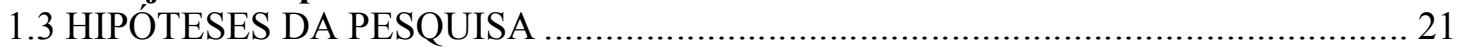

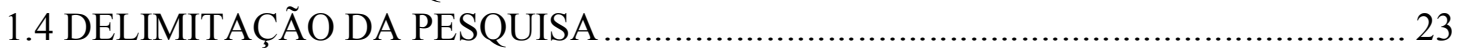

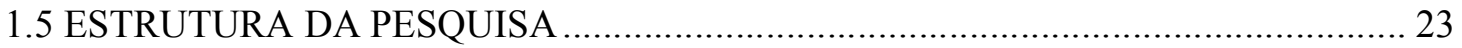

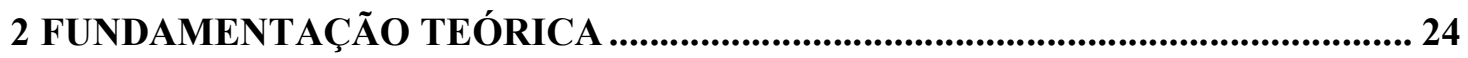

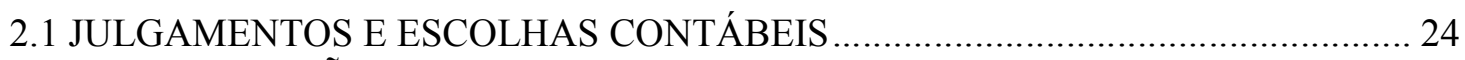

2.2 CONSIDERAÇÕES ACERCA DO OTIMISMO …................................................. 27

2.2.1 A origem do otimismo: como natureza humana ou característica

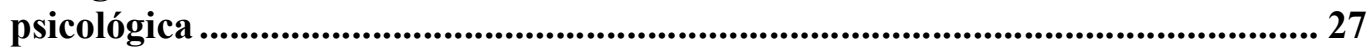

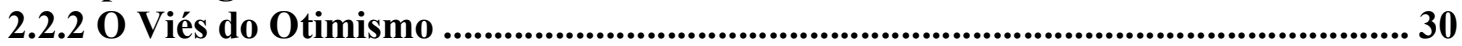

2.2.3 Formas de Avaliação do Viés Otimista................................................................. 32

2.2.4 Fatores Moderadores do Viés Otimista ............................................................ 34

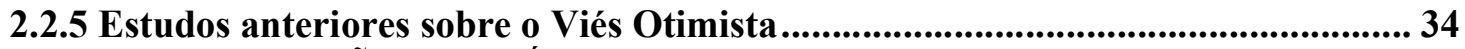

2.3 A EVIDENCIAÇÃO CONTÁBIL: ATIVOS E PASSIVOS CONTIGENTES ................. 36

2.3.1 A importância da Evidenciação Contábil.....................................................36

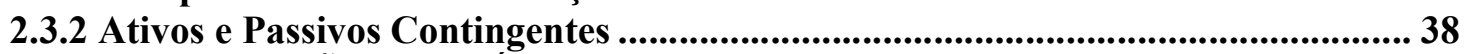

2.4 A INFORMAÇÃO CONTÁBIL NO CONTEXTO DO CONSERVADORISMO

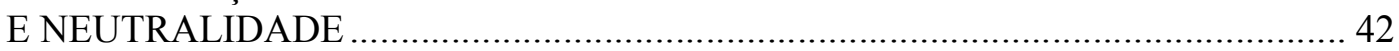

2.5 SOBRE AS VARIÁVEIS DE CONTROLE ...................................................... 45

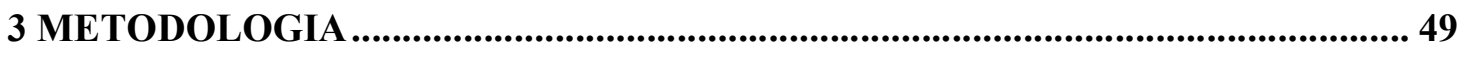

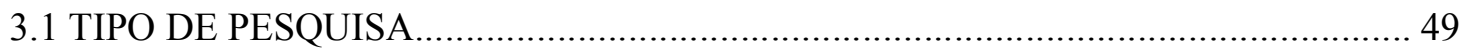

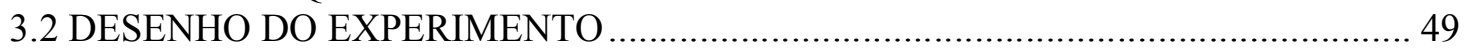

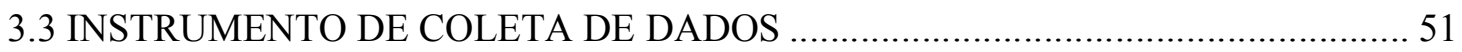

3.3.1 Relacionada à medição do Viés Otimista ......................................................... 51

3.3.2 Relacionado ao julgamento de probabilidades dos cenários ............................... 53

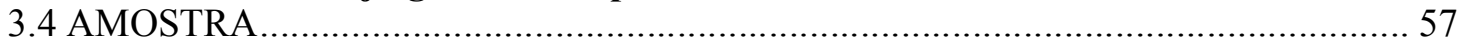

3.4.1 Procedimento para obtenção da amostra .......................................................... 57

3.4.2 A composição da Amostra Total e Reduzida.......................................................... 57

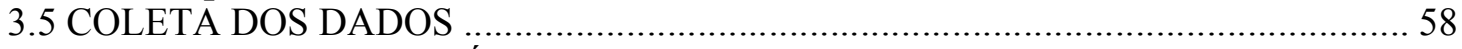

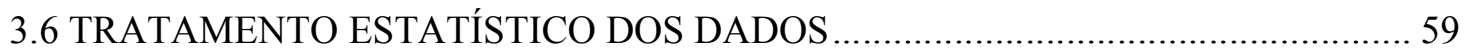

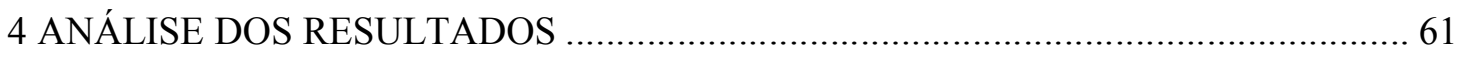

4.1 DIMENSIONALIDADE E CONFIABILIDADE DOS DADOS .................................... 61

4.2 CARACTERIZAÇÃO DOS PARTICIPANTES E CÁLCULO DO VIÉS

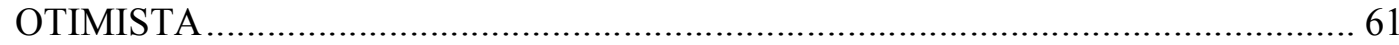

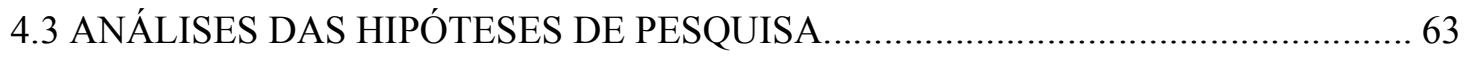




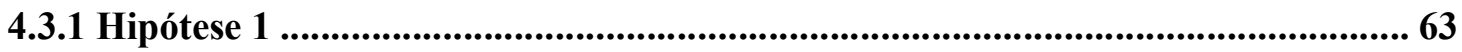

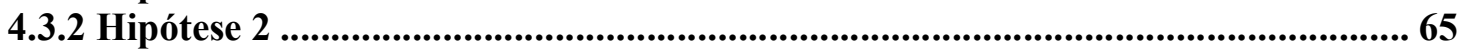

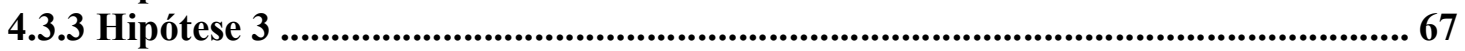

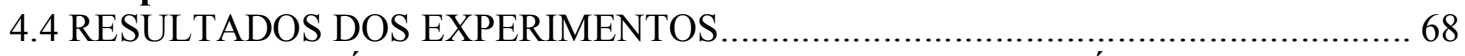

4.5 EFEITOS DO VIÉS OTIMISTA NOS JULGAMENTOS CONTÁBEIS..................... 68

5 CONSIDERAÇÕES FINAIS ..................................................................................... 73

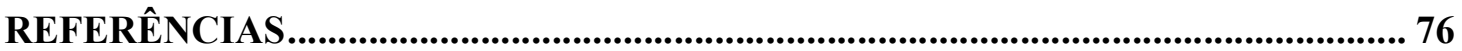

APÊNDICE A - Instrumento de Pesquisa .................................................................... 82

APÊNDICE B - Dados Descritivos ................................................................................. 105

APÊNDICE C - Dados da Análise ...................................................................................... 107

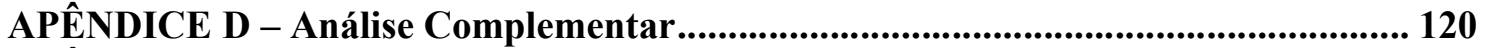

APÊNDICE E - Proposta do Curso .............................................................................. 128 


\section{INTRODUÇÃO}

\subsection{CONTEXTUALIZAÇÃO DO PROBLEMA E JUSTIFICATIVA}

O processo de convergência das normas internacionais da contabilidade modificou não somente a forma do registro dos itens patrimoniais mas, principalmente, a proposta ampliou o escopo do julgamento, de tal forma que se evidencie, nos relatórios contábeis, uma representação cada vez mais próxima da realidade da organização. Dentre as modificações trazidas por essas normas merece destaque, neste sentido, aquelas referentes às contingências, onde existe uma expressiva parcela de julgamento.

Ao se discutir acerca das exigibilidades contingentes, tem-se como definição clássica uma obrigação "que pode surgir dependendo de um evento futuro" e, com relação à contingência, a definição engloba "uma situação existente e um conjunto de incertezas quanto aos ganhos e perdas possíveis" que são dirimidas com ou sem a ocorrência dos eventos futuros.

Dessa forma, existindo um valor provável, mesmo que estimado, a recomendação era de registrá-lo na contabilidade. Com relação às perdas contingentes, elas não deviam ser registradas nas demonstrações contábeis, apenas divulgadas nas notas explicativas caso a probabilidade de ocorrência do evento futuro fosse razoável e, por fim, nenhuma recomendação estava disponível caso fosse remota a probabilidade de sua ocorrência. Observa-se a presença de incerteza e, consequentemente, uma lacuna que permite $o$ julgamento quanto às estimativas de valores e, principalmente, quanto à ocorrência de eventos futuros.

Atualmente, o passivo contingente tem, como base, a probabilidade de ocorrência do desembolso (provável, possível ou remota), demandando um tratamento contábil distinto conforme o julgamento dessa probabilidade. Contudo, a recomendação é de se constituir provisão se a probabilidade de ocorrência for maior que a não ocorrência, ou seja, as orientações conduzem ao entendimento de se evitar que se efetuem provisões em excesso. Dessa maneira, observa-se um aumento do escopo do julgamento, pois além da análise dos eventos futuros fica a critério do julgador definir o que considera como "mais provável" de ocorrer.

Nesse contexto, o preparador das informações contábeis, uma vez inserido em um ambiente que revela maior espaço discricionário, pode exibir em seu julgamento um otimismo exagerado e assim, incorre no risco de comprometer a neutralidade e a relevância dessa 
informação, características consideradas imprescindíveis para a manutenção da sua utilidade. De acordo com o International Financial Reporting Standards- IFRS (2010), para garantir a utilidade da informação financeira, ela deve ter valor preditivo e valor confirmatório, além de representar, fielmente, o fato que pretende apresentar, ou seja, ser completa, neutra e livre de erro.

No entanto, nem sempre os indivíduos conseguem manter a imparcialidade da informação em todas as ocasiões, principalmente se ela for elaborada em condições de incerteza. A neutralidade pode ser prejudicada por uma série de fatores, dentre os quais estão aqueles relacionados ao processo cognitivo.

O otimismo exagerado pode ser compreendido à medida que os indivíduos, comparando-se aos outros, avaliam que suas probabilidades com relação à participação em eventos negativos são menores que as dos seus pares e maiores para os eventos positivos (WEINSTEIN, 1980). Considerando que o excesso de otimismo é inerente ao ser humano, os preparadores das informações contábeis uma vez influenciados por esse viés podem reagir de forma e intensidade diferente e assim comprometer a qualidade ao elaborarem as informações.

As teorias advindas da psicologia tendem a ser descritivas e não assumem que as pessoas se comportam com os modelos normativos (KOONCE; MERCER, 2005). Nesse sentido, essas teorias oferecem ajuda no processo de compreensão da tomada de decisão e dos vários fatores influenciadores.

Apesar de Libby et al. (2002) reconhecerem a importância dessas teorias, os autores admitem o pouco aproveitamento da teoria na contabilidade. Contudo, os estudos realizados por Koonce e Mercer (2005) revelam que 71\% das publicações de contabilidade financeira experimental dependem das teorias psicológicas para o processamento de previsões e interpretações dos resultados.

De acordo com Armor e Taylor (1998), são várias as fontes das quais se originam as expectativas excessivamente otimistas. As causas derivam de sistemas cognitivos, motivacionais e afetivos, dentre outros. Quando as pessoas elaboram suas previsões, fazem uso da simulação mental, ou seja, há uma necessidade de se envolver em todas as ações no intuito de alcançar os resultados desejados. Entretanto, os autores afirmam que boa parte do sucesso atribuído aos cenários futuros é determinada por causas motivacionais; contudo, alertam que as restrições cognitivas nas construções desses cenários desempenham um importante papel.

De mesma importância, os fatores motivacionais e afetivos são reconhecidos como fontes de crenças otimistas. Outra razão que pode explicar esse viés se relaciona à crença da 
expectativa da perda pessoal, embora o otimismo possa trazer benefícios em algumas situações (WEINSTEIN; KLEIN, 1996).

Analisando-se a contribuição teórica do viés otimista, Shepperd et al. (2013) ressaltam que esse conceito se expande para além da psicologia, pois se encontra inserido no campo das ciências sociais como o direito, economia e ciências da decisão. Contudo, as evidências empíricas tratam da percepção dos indivíduos quanto aos riscos associados às doenças graves e contagiosas, uso de drogas, acidentes automobilísticos, atividades relacionadas à internet, sucesso empresarial, dentre outros (WEINSTEIN, 1980; SHEPPERD et al., 1996, 2005, 2013; CAMPBELL et al., 2007; DILLARD et al., 2009; VALERDI e BLACKBURN, 2009; UCBASARAN et al., 2010; HILARY; HSU; SEGAL, 2013).

Apesar de extenso, o número de pesquisas da aplicação do viés otimista, conforme exposto anteriormente, não foi possível identificar estudos que associam o viés otimista às práticas contábeis, especialmente, ao julgamento da constituição de ativos e passivos contingentes. No entanto, observa-se que os fundamentos do viés permitem a sua aplicação no campo da contabilidade.

De acordo com o Comitê de Pronunciamentos Contábeis (CPC) 25, o uso de estimativas não prejudica a confiabilidade das demonstrações contábeis. Esse fato se aplica para as provisões, que, pela sua natureza, são mais incertas do que a maior parte de outras informações que constam no balanço (CPC, 2009). Com exceção de eventos extremamente raros, é possível que a entidade determine um conjunto de desfechos possíveis e, assim, fazer uma estimativa da obrigação que seja suficientemente confiável para ser usada no reconhecimento da provisão (CPC, 2009). No entanto, de acordo com as orientações descritas no CPC 25 (CPC, 2009, p.13, grifo nosso) “[...]é preciso ter cuidado ao realizar julgamentos em condições de incerteza, para que as receitas ou ativos não sejam superavaliados e as despesas ou passivos não sejam subavaliados". Observa-se uma preocupação contida na norma com a questão do enviesamento auto-interessado, ou, em outras palavras, retrata o status do indivíduo de um eterno conflito entre seus desejos e necessidades existentes.

Segundo o IASB (2010) os eventos incertos devem ser referidos em notas explicativas ou reconhecidos nas demonstrações contábeis, se sua ocorrência for estimada como possível ou provável. No entanto, caso a ocorrência desses eventos seja julgada como remota, a informação sequer será demonstrada.

Os resultados de algumas pesquisas analisadas por Bonner (2008) revelam que os elaboradores, usuários, auditores e reguladores da informação contábil nem sempre fazem julgamentos e decisões de alta qualidade. Isto traz, como consequência, a produção de erros 
sistemáticos e a baixa qualidade do julgamento e processo decisório, os quais conduzem a sérias implicações econômicas tanto para os indivíduos que tomam as decisões como para as empresas nas quais eles trabalham.

Nesse contexto, caso as decisões contábeis contenham um excesso de otimismo, o fato pode acarretar prejuízos no tocante à informação contábil, que vai desde a ausência de neutralidade, imprecisão das estimativas até a falta de reconhecimento, impactando, dessa forma, na confiabilidade e na interpretação dos relatórios contábeis.

Dissertar acerca do excesso de otimismo no campo da contabilidade apresenta contribuições que podem ser observadas sob vários escopos. No campo do conhecimento, tem-se a transdisciplinaridade, ao se trazer uma teoria da psicologia e evidenciar a sua aplicação no contexto da contabilidade. Com relação à metodologia utilizada, pode-se dizer que o quase-experimento trouxe contribuições. A técnica é bastante difundida nas ciências sócias, contudo, com menor aplicação no campo da contabilidade. Essa forma de aplicação de pesquisa, da forma como foi desenhada, possibilitou a coleta presencial e de livre espontaneidade por parte do respondente. Embora seja complexa a comprovação, acredita-se que, dessa maneira, tenha sido possível minimizar o viés de resposta.

No que diz respeito ao processo decisório na contabilidade, a presença desse viés pode acarretar escolhas que causem prejuízo à organização, à medida que o profissional contábil, exageradamente otimista, deixa de tomar medidas de precaução.

E, por fim, identificar esse viés na carreira do profissional contábil parece oportuno, pois a presença do excesso de otimismo pode bloquear sua percepção da realidade e, em função disso, diminui a sua preocupação com a atualização profissional.

Ao se considerar o exposto acima, a questão a ser investigada é a seguinte: o otimismo exagerado afeta a avaliação dos ativos e passivos contingentes? 


\subsection{OBJETIVOS}

\subsubsection{Objetivo geral}

O estudo tem, por objetivo, analisar os efeitos do viés emocional do otimismo exagerado no julgamento do profissional contábil, no que se refere à avaliação das probabilidades de ocorrência de ativos e passivos contingentes.

\subsubsection{Objetivos específicos}

Para alcançar o objetivo geral, foram estabelecidos os seguintes objetivos específicos:

a) Mensurar o grau de otimismo exagerado dos participantes da pesquisa;

b) Avaliar se a experiência pessoal prévia e controlabilidade afetam o grau de otimismo dos indivíduos e/ou as avaliações de probabilidades de eventos contingentes;

c) Investigar a influência das variáveis forma de contratação, fonte adicional de informações e existência de fiscalização de tarefas nas estimativas de probabilidades de eventos contingentes apresentadas pelos respondentes.

\subsection{HIPÓTESE DA PESQUISA}

De acordo com os objetivos apresentados anteriormente, essa pesquisa parte de uma hipótese principal, da qual derivam as demais hipóteses operacionais. O conjunto de hipóteses pode ser classificado como sendo de origem comportamental, pois tem, como base, o julgamento a ser realizado pelos participantes do estudo.

Para Sharot (2011) o otimismo irreal é uma característica humana generalizada que influencia os domínios que vão desde as relações pessoais à política e finanças, o que evidencia que o viés otimista além de estar presente em todas as realizações da espécie humana, prevalece em todos os grupos de idade, raça e nível sócio-econômico. De acordo com Weinstein (1980) o viés otimista pertence ao sujeito e não à situação ou contexto. Desse modo, pretende-se verificar como os participantes da pesquisa julgam as situações em um contexto empresarial. 
Com o intuito de fazer essa verificação, foram elaborados cenários que preservam as características de ativos e passivos contingentes, possíveis de acontecer em uma entidade, para os quais os indivíduos estimam a probabilidade de ocorrência desses eventos.

Sendo assim, uma vez identificada a presença do viés otimista no indivíduo, é esperado que tal otimismo influencie as estimativas quanto às probabilidades de ocorrências de cenários contingentes, de modo a superestimar os cenários ativos e subestimar os cenários passivos.

Com base na hipótese de pesquisa acima descrita formularam-se as seguintes hipóteses operacionais:

$\mathrm{H}_{1}=$ Indivíduos excessivamente otimistas tendem a superestimar a avaliação dos ativos contingentes da entidade empresarial;

$\mathrm{H}_{2}=$ Indivíduos excessivamente otimistas tendem a subestimar a avaliação dos passivos contingentes;

$\mathrm{H}_{3}=$ Quanto maior a experiência pessoal prévia menor tende a ser o grau do viés otimista e quanto maior o controle, maior tende a ser o grau do viés otimista.

Acredita-se que os fatores moderadores experiência pessoal prévia e a controlabilidade percebida causem um forte efeito no otimismo exagerado. A literatura evidencia a importância de se conhecer o grau do excesso de otimismo presente em cada indivíduo, à medida que ele influencia o modo do processamento de informações, nesse sentido, Helweg-Larsen e Shepperd (2001) classificam os fatores moderadores do viés em dois grupos: i) de estimativas de riscos pessoais, ii) de estimativas da pessoa média ou alvo de comparação.

A redução no viés é observada com o aumento da experiência prévia do indivíduo, à medida que aumenta a probabilidade de as pessoas acreditarem que suas chances são maiores do que a média para os eventos negativos. Helweg-Larsen e Shepperd (2001) comentam que, em caso desses tipos de eventos, torna-se mais fácil para a pessoa imaginar-se no papel de vítima devido à disponibilidade da experiência anterior nessa condição.

Já com relação ao controle, um evento tem condições de ser controlável se o indivíduo acredita que possam ser tomadas ações que visam a aumentar a probabilidade de atingir um resultado desejável, trazendo para si ações que facilitam o cumprimento de metas (WEINSTEIN, 1980). Dessa forma, à medida que o controle percebido aumenta, as chances de um indivíduo tendem a ser menores do que a média para eventos negativos. O contrário também se confirma, ou seja, a chance de um indivíduo tende a ser maior do que a média para eventos positivos. 


\subsection{DELIMITAÇÃO DA PESQUISA}

Embora se aceite a concepção de que o pessimismo exagerado também possa vir a afetar as escolhas contábeis, bem como, de que a sua presença no indivíduo não revele apenas consequências que se traduzem em prejuízo no tocante às decisões da empresa, é objeto dessa tese tratar tão somente dos efeitos do excesso de otimismo nas decisões contábeis.

Da mesma forma, esse estudo não tem como propósito avaliar as relações do viés otimista com outros vieses de cunho cognitivo e/ou emocionais.

Assim sendo, a métrica utilizada para identificar a presença desse viés no indivíduo contempla em seu escopo a captura do excesso de otimismo, deixando-se claramente definido que a não constatação da sua presença não deve ser levada a interpretação de que esse indivíduo seja considerado um pessimista.

\subsection{ESTRUTURA DA PESQUISA}

Este estudo está organizado em cinco capítulos. No primeiro capítulo encontra-se a Introdução, a qual tem como objetivo contextualizar o leitor acerca do assunto a ser discorrido, os antecedentes do problema, bem como a justificativa e os objetivos geral e específicos da pesquisa.

O segundo capítulo traz a revisão da literatura que fundamenta a tese. Nesse contexto, são abordadas teorias advindas da psicologia que versam sobre o viés otimista, bem como, das temáticas que tratam do julgamento e evidenciação de ativos e passivos contingentes.

No terceiro capítulo, são revelados os caminhos metodológicos adotados. Sendo assim, discorrer-se-á sobre a formação e a composição da amostra, do instrumento de pesquisa utilizado para a coleta dos dados, como também, sobre as técnicas e análises estatísticas.

No quarto capítulo, são mostradas a descrição e a análise dos dados coletados e, no quinto capítulo, são feitas as considerações finais, além das contribuições para estudos futuros sobre a temática discorrida e as limitações da pesquisa.

Por fim, o apêndice apresenta informações complementares que visam a esclarecer sobre o instrumento de pesquisa utilizado, bem como, as memórias de cálculos estatísticos. 


\section{FUNDAMENTAÇÃO TEÓRICA}

\subsection{JULGAMENTOS E ESCOLHAS CONTÁBEIS}

O estudo de julgamento e de tomada de decisão surgiu como um campo na intersecção de problemas importantes em direito, medicina, economia e negócios (REYNA e RIVERS, 2008), tendo, como foco das investigações, o risco e a incerteza.

Andrade (2011) ao construir o conceito de incerteza com base em versões já expressas na economia, percebe que, para uma melhor compreensão desse conceito, é necessário distinguir a incerteza do risco, pois, enquanto o risco é visto com uma probabilidade que seja mensurável, na incerteza, essas probabilidades são desconhecidas. Com relação à incerteza, Andrade (2011) a classifica em dois tipos: a ontológica, também chamada de sistêmica, a qual se refere ao ambiente em si e a epistêmica, que trata da incerteza acerca da compreensão do ambiente.

De acordo com o CPC 25 (2009), o risco descreve a variabilidade de desfechos. Dessa forma, ao se fazer uma nova avaliação do risco pode-se ter um aumento de valor do passivo em função de uma nova mensuração. No entanto, é preciso ter cautela ao se realizar julgamentos em condições de incerteza, no intuito de garantir um equilíbrio para que não haja superavaliação das receitas ou ativos e nem subavaliação de despesas ou passivos, como também, a criação de provisões excessivas.

No que diz respeito ao julgamento, de acordo com Bonner (2008), o termo se refere à formação de uma ideia, opinião ou estimativa de um evento. Nesse contexto, Bonner (2008) exemplifica que, na contabilidade, o julgamento assume a forma de previsões de eventos futuros. Para Popa et al. (2011), o julgamento profissional representa o processo de formação de uma opinião.

Trotman, Tan e Ang (2011), no que tange ao julgamento na contabilidade, apresentam dois grupos de julgadores: a) os auditores e b) os preparadores dos demonstrativos financeiros. Cabe ao último grupo, além de estimar as probabilidades futuras, decidir sobre o que incluir nos relatórios, como também, sobre quais tratamentos contábeis devem ser aplicados.

O estudo de Popa et al. (2011) teve, como objetivo, identificar as características do julgamento profissional em várias áreas como a da saúde, engenharia, advocacia e auditoria a fim de comparar e verificar a possibilidade de se criar um modelo geral de julgamento para as atividades dos profissionais liberais. Os achados do estudo revelam que o julgamento 
profissional é um processo que inclui referências às normas, sensibilidade à empresa ou às suas expectativas, justificativa e identificação de consequências, além da competência, experiência e habilidades de quem julga.

Popa et al.(2011) comentam que muitos especialistas reconhecem a necessidade de unificação do modo como exercer o seu julgamento. Apesar da legislação fornecer indicações de como conduzir esse processo, os especialistas afirmam que os princípios e as orientações oferecidas não são suficientes para realizar um julgamento que seja aceito de forma específica e geral. Nesse contexto, cabe destacar que o uso de estimativas contribui no aumento da complexidade da unificação.

Knight (1921, p.223 apud ANDRADE, 2011), ao se referir à estimativa, a define como sendo um "[...] julgamento intuitivo que orienta o processo de tomada de decisão dos agentes; estes agem, de modo geral, com base em estimativas e não [em] inferências", contudo, não faz uso de raciocínio lógico estrito. Dessa forma, Andrade (2011) comenta que a propensão ao erro, associado aos julgamentos, fica ainda mais destacado pela incerteza.

Nos estudos de Bennett, Bradbury e Prangnell (2006), ao estabelecerem uma comparação entre normas, princípios e as implicações deles no processo de convergência, concluem que há duas questões principais que precisam ser consideradas. A primeira se refere à redução da ponderação entre comparabilidade e consistência - com relação às outras características qualitativas - e, a segunda, trata do aumento do subsídio do julgamento profissional tanto em nível de transação, como em nível financeiro. Contudo, ambas as questões dependem das escolhas contábeis realizadas pelos indivíduos.

Beresford e Sloper (2008) ao se referirem às teorias sobre o julgamento, tomada de decisão e escolha, as classificam em duas categorias: a) as teorias normativas de cognição e b) as teorias descritivas de cognição. Enquanto a primeira se preocupa sobre "como devemos raciocinar, fazer julgamentos e tomar decisões" (cuja natureza está inserida na lógica formal, teoria da probabilidade e teoria da decisão) a segunda se preocupa em descrever e compreender como funcionam os processos - através dos quais as pessoas fazem escolhas.

Para Beresford e Sloper (2008), a escolha é o resultado de um processo que envolve a avaliação e o julgamento, ao mesmo tempo em que os processos inerentes às escolhas envolvem cognição e, sendo assim, as teorias psicológicas se concentram em explicar como as pessoas fazem escolhas.

Para Fields, Lys, e Vincent (2001) uma escolha contábil pode ser definida como uma decisão que tenha por objetivo influenciar, seja na forma ou substância, a informação contábil. Dessa forma, pode-se dizer que as escolhas afetam o nível de divulgação. 
Beresford e Sloper (2008), ao tratarem da escolha, descrevem a forma como as pessoas pensam sobre as opções e as prováveis consequências de cada escolha; contudo, existem fatores emocionais em jogo, pois as pessoas desenvolvem sentimentos sobre a decisão e as expectativas sobre esses sentimentos podem resultar na escolha de outras opções disponíveis.

Para Green e Myerson (2004), as escolhas podem ser vistas sob três dimensões (quantidade, tempo e probabilidade) para as quais são oferecidas as alternativas. Contudo, os autores alertam que a escolha é relativamente previsível quando as alternativas diferem em apenas uma dimensão; no entanto, os problemas surgem quando as opções de escolha diferem em mais de uma dimensão.

No estudo de Todorov, Coelho e Hanna (2003) - que trata das probabilidades e escolhas -, os pesquisadores perceberam que as pessoas, em geral, subestimam consequências com atrasos longos e superestimam consequências com probabilidades baixas; segundo eles, ao mostrar essa situação tomando como exemplo um fumante, revelam que seu comportamento ignora todas as advertências sobre os males do cigarro enquanto não sente os efeitos maléficos do cigarro sobre a sua saúde. Ou seja, a possibilidade de contrair uma doença, daqui a 5 anos, decorrente do vício hoje tem pouco valor para esse indivíduo.

Na pesquisa de Fields, Lys e Vincent (2001) os estudos sobre as escolhas contábeis foram classificados em três grupos: i) custos de agência, ii) assimetria da informação, iii) outras externalidades. Os custos de agência estão relacionados com questões contratuais, como a compensação de gestão e convênios de dívida; já as assimetrias da informação são geralmente associadas a relação entre os gestores e os investidores, e o último grupo se relaciona com questões contratuais e não contratuais com terceiros.

Finucane, Peters e Slovic (2002) comentam que os julgamentos e as escolhas podem resultar da interação das características individuais e da natureza da tarefa; eles exemplificam que, quando os sentimentos afetivos assumem um aspecto relevante com relação a um estímulo podem influenciar fortemente as escolhas em um contexto, no entanto, em outra situação, o mesmo aspecto pode ser menos acentuado e, dessa forma, produzir sentimentos afetivos menos intensos e, como consequência, uma fraca influência na escolha.

Para Beresford e Sloper (2008), todo processo de escolha tem componentes cognitivos e emocionais. Em nível geral, a emoção e a cognição podem ser vistas como tipos de processamento de informação, contudo, com funções diferentes. Os autores comentam que a emoção serve como um alerta para os indivíduos sobre particularidades de determinada 
situação e, dessa forma, fornecem orientação para os processos cognitivos e de comportamento.

Nesse contexto, Svenson (2003, apud BERESFORD, SLOPER, 2008) discorre sobre a relação do humor com a estimativa de probabilidades ao afirmar que o bom humor pode levar a superestimar a probabilidade de resultados positivos e subestimar a probabilidade de resultados negativos e que o mau humor provoca o efeito oposto.

Por outro lado, os indivíduos diferem entre si com relação à intensidade dos seus sentimentos afetivos e, assim, perante o mesmo contexto ou tarefa, determinada pessoa pode ter fortes sentimentos afetivos que orientam suas decisões, ao passo que, em outro indivíduo, a manifestação desses sentimentos pode ser mais fraca e, em decorrência disso, as decisões sofrem menos impactos (BERESFORD; SLOPER, 2008).

\subsection{CONSIDERAÇÕES ACERCA DO OTIMISMO}

\subsubsection{A origem do otimismo: como natureza humana ou característica psicológica}

Peterson (2000) comenta, em suas pesquisas, que a afirmação mais forte de que o otimismo é inerente à natureza humana vem dos escritos de Tiger, que o descreve como sendo parte integrante da natureza humana com característica definidora e adaptativa. Pelo fato de o otimismo levar a pensar sobre o futuro, Tiger chega a especular que ele pode levar à evolução do ser humano e, sob esse prisma, confirma que o otimismo não é derivado de alguma outra característica psicológica e sim intrínseco ao ser humano (TIGER, 1979 apud PETERSON, 2000).

No entanto, outras discussões abordadas por Tiger apresentam o otimismo como diferença individual (TIGER, 1979 apud PETERSON, 2000). Os indivíduos possuem características e essas influenciam o otimismo apresentando-o em diferentes graus (PETERSON, 2000).

$\mathrm{O}$ autor explica que as duas abordagens são compatíveis à medida que a natureza humana fornece um otimismo inicial, contudo algumas pessoas se revelam mais otimistas ao passo que outras o são menos.

Puri e Robinson (2007) tiveram como foco da pesquisa as decisões econômicas individuais e, ao verificarem a ligação do grau de otimismo a uma série de decisões econômicas, constatam que os indivíduos que apresentaram um otimismo moderado tendem a tomar decisões de maneira mais sensata, contudo, aqueles que exibiram um otimismo extremo 
suas decisões aparentemente se mostraram irracionais. Os autores revelam que os otimistas moderados mostram hábitos financeiros mais prudentes e possuem uma visão de longo prazo, enquanto que os otimistas extremos só visualizam planejamentos de curto prazo. Ou seja, os moderados economizam mais e os extremos poupam menos.

A visão de otimismo apresentada por Scheier e Carver (1987) revela que os indivíduos veem o mundo em diferentes perspectivas. Algumas pessoas acreditam que apenas coisas boas irão acontecer ao longo de sua trajetória, são os otimistas, enquanto outros indivíduos esperam justamente o contrário. Os pessimistas aguardam maus resultados em seus caminhos. A expressão otimismo disposicional se refere às diferenças individuais em esperas de resultado generalizadas, consideradas relativamente estáveis através de tempo e contexto (SCHEIR; CARVER, 1987).

Uma visão diferente do otimismo disposicional pode ser vista em um dos clássicos de Hanna Barbera. O desenho conta as aventuras de um leão e uma hiena. Lippy, um otimista animado que sempre esperava que seus planos dessem certo, enquanto Hardy, muito pessimista, nunca acreditava no sucesso e dizia a famosa frase "Oh céus! Oh vida! Oh azar! Isto não vai dar certo!" (HANNA; BARBERA, 1962).

Nesse contexto, o otimismo é analisado a partir do comportamento das pessoas no processo de alcance de seus objetivos. Assim, Carver e Scheier (1981, apud PETERSON, 2000) descrevem o otimismo numa abordagem de auto-regulação, os indivíduos à medida que são questionados sobre as dificuldades para a realização das metas podem continuar a acreditar no atingimento da meta (otimistas) ou simplesmente desistem (pessimistas).

Outra forma de ver o otimismo de acordo com Seligmann et al. (1993, apud PETERSON, 2000) é em termos de um estilo explicativo, onde o indivíduo explica a causa dos eventos bons e ruins. Enquanto o otimista justifica os momentos ruins com causas externas, instáveis e específicas, o pessimista apresenta causas internas, estáveis e globais.

Existe outra linha de pesquisa que relaciona o otimismo e os sistemas neurais. Kuhnen e Knutson (2005) confirmam, em seus estudos realizados através de imagens do cérebro humano, que as antecipações dos ganhos e das perdas são acessadas por sistemas neurais diferentes. Enquanto os sentimentos positivos são associados com antecipação dos ganhos, os negativos se relacionam à antecipação das perdas. Dickhaut (2009) comenta que as pesquisas no campo neuroeconômico sugerem que o comportamento do cérebro é consistente com o princípio do conservadorismo, pois ele processa os ganhos e as perdas de forma diferente.

As várias formas de ver o otimismo conforme exposto esclarece que ele é inerente ao indivíduo; contudo, existem vários fatores que influenciam e assim promovem diferentes 
graus do otimismo no ser humano, revelando-se mais acentuado em uns e menos acentuados em outros.

Nas pesquisas que relacionam os sistemas neurais e a forma como eles mediam o viés otimista, os achados revelam que algumas regiões do cérebro (córtex cingulado anterior, as regiões medio-frontal e regiões adjacentes pré-frontais laterais) estão associadas com o viés otimista e servem como sistema de mediação para os erros de estimativa com relação aos eventos futuros. Além de que, as pesquisas mostram que há dissociação dos acontecimentos positivos e negativos nessas regiões mediadoras (SHAROT et al., 2007, 2011).

Sharot (2011) mostra que quando as pessoas fornecem estimativas sobre o futuro, elas são, muitas vezes, exageradamente otimistas e que esse viés não consegue ser explicado pelas teorias de aprendizagem. Esta autora evidencia, em seu estudo, que os ajustes de expectativas que deveria acontecer a partir de novas informações muitas vezes não geram expectativas realistas, o que contraria a teoria da aprendizagem. E, assim, os efeitos desse viés em termos de sociedade podem ser vistos por dois ângulos: a) o benéfico que está relacionado com a promoção da saúde e bem estar, à medida que diminui a ansiedade e o stress; b) o maléfico que reduz a importância e o planejamento de ações preventivas (SHAROT, 2011).

Por fim, com o intuito de melhorar a compreensão da temática desta pesquisa, parece pertinente evidenciar as várias terminologias dispostas na literatura, mas que são utilizadas para transmitir a mesma essência. Shepperd et al. (2013) revelam que os termos otimismo não realístico, otimismo comparativo, viés de otimismo, sobre otimismo, planejamento de falácia e ilusões positivas são expressões associadas aos estudos que versam sobre o viés otimista. Coelho (2012) faz uso da expressão otimismo irrealístico (UO) ao tratar do viés. Nesse contexto, para fins desta tese, consideram-se sinônimos os termos otimismo não realístico, otimismo irrealista (UO), viés otimista e excesso de otimismo.

Esta tese tem como foco discorrer sobre o viés otimista, no entanto, devido às suas peculariedades, sentiu-se a necessidade de descrever algumas diferenças entre esse viés e o otimismo disposicional (Quadro 1). 
Quadro 1 - Viés otimista x Otimismo Disposicional

\begin{tabular}{|l|l|l|}
\hline Diferenças quanto à & Viés Otimista & Otimismo Disposicional \\
\hline Origem & Emocional & Cognitiva \\
\hline Crença & $\begin{array}{l}\text { Probabilidade superior à seus pares p eventos } \\
\text { positivos e inferior p eventos negativos }\end{array}$ & $\begin{array}{l}\text { Característica Cognitiva } \\
\text { Individual e Personalidade }\end{array}$ \\
\hline $\begin{array}{l}\text { Expectativa Positiva do } \\
\text { Futuro }\end{array}$ & Sobre eventos específicos & De forma generalizada \\
\hline Medição & $\begin{array}{l}\text { Forma Absoluta ou Comparativa e em Nível de } \\
\text { Grupo ou Individual }\end{array}$ & LOT, LOT-R \\
\hline
\end{tabular}

Fonte: Dados da pesquisa, 2016.

Com relação às origens, o viés otimista está inserido no campo da emoção (POMPIAN, 2006) ao passo que o otimismo disposicional está no campo da cognição (SCHEIER; CARVER, 1987). Os vieses cognitivos decorrem de um raciocínio falho, contudo, possíveis de serem corrigidos à medida que se melhorem as informações. Por outro lado, as polarizações emocionais, originárias da intuição e não de cálculos conscientes, são mais difíceis de se corrigir (POMPIAN, 2006).

Scheier e Carver (1985) explicam que as pessoas diferem umas das outras na forma de abordar o mundo. Algumas tendem a ser favoráveis na sua perspectiva. Esses otimistas acreditam que coisas boas acontecerão com eles ao invés de coisas ruins. Outras pessoas têm um conjunto oposto de crenças. Esses pessimistas tendem a antecipar resultados ruins. Além disso, a observação casual sugere que estas diferenças individuais são relativamente estáveis ao longo do tempo e contexto.

Com relação ao excesso de otimismo, Armor e Taylor (1998) o definem em termos de expectativas sobre eventos específicos. Na ótica do otimismo disposicional, por sua vez, um indivíduo poderia revelar expectativas globais otimistas e, ao mesmo tempo, mostrar um pessimismo em relação a uma situação específica (SCHEIER; CARVER, 1987).

Quanto às medições, o viés otimista pode ser medido tanto em nível de grupo ou individual, de forma absoluta ou comparativa (SHEPPERD et al, 2013). No que se refere à métrica do otimismo disposicional, apesar de ter vários instrumentos, o mais difundido é o Teste Orientado à Vida (LOT), proposto por Scheir e Carver (1987) e sua versão revisada (LOT-R) proposta por Scheir, Carver e Bridges em 1994.

\subsubsection{O Viés do Otimismo}

A definição de otimismo apresentada por Tiger (1979, apud PETERSON, 2000, p.44) refere-se a um estado de espírito ou atitude associado a uma expectativa sobre o futuro social 
ou material, aquela que o avaliador considera como socialmente desejável, como vantagem ou prazer. Peterson (2000), ao fazer referência a esse conceito, interpreta que não pode haver um otimismo único ou um objetivo caracterizado pelo seu conteúdo, pois o conceito otimista depende do que indivíduo considera como desejável.

Nesse contexto, Peterson (2000) explica o otimismo distinguindo-o em dois tipos: o grande (big optimism) e o pequeno otimismo (little optimism). Com relação ao grande otimismo, ele o descreve como sendo uma tendência biológica, preenchida pela cultura, com um conteúdo socialmente capaz, o qual leva a resultados desejáveis em função da produção de um estado geral de vigor. O pequeno otimismo decorre, por sua vez, de uma história de aprendizagem peculiar e conduz a resultados desejáveis à medida que se predispõe a ações específicas que são adaptáveis em situações concretas. Ao discutir a relação entre os dois, o autor descreve que não há dúvidas de que sejam correlacionados, contudo, admite que os determinantes dos dois possam ser diferentes e, sendo assim, as formas de incentivo requerem estratégias diferentes.

Weinstein (1980) foi o primeiro a verificar, em suas pesquisas, o excesso de otimismo. A partir das crenças da população, o autor observa nos indivíduos a invulnerabilidade, à medida que eles esperam acontecimentos de infortúnio para os outros e não para si. Chama a atenção que esse pensamento não contém apenas uma perspectiva esperançosa da vida, mas também, um erro no julgamento e que isso pode ser considerado um otimismo irreal. $\mathrm{O}$ autor foi o primeiro a evidenciar esse termo ${ }^{1}$.

Em um dos seus estudos, Weinstein (1980) pediu aos participantes que fornecessem uma estimativa da probabilidade de experimentar uma doença, em comparação com outras pessoas. Como resultado, tem-se que o indivíduo avalia seu risco como abaixo da média para uma variedade de doenças. Contudo, o autor alerta que se todas as pessoas afirmam que suas chances de experimentar um evento negativo se encontram abaixo da média, estão evidenciando claramente um erro sistemático, sendo fácil fazer a descoberta desse viés em nível de grupo.

Weinstein (1980) notou que os indivíduos, ao avaliarem a ocorrência de eventos, quando comparados aos outros, acreditam que os eventos negativos são menos prováveis de acontecer com eles, no entanto, para os eventos positivos essa situação se inverte. Contudo, à medida que esse comportamento se manifesta no indivíduo, os efeitos do viés podem ser

\footnotetext{
${ }^{1}$ Unrealistic Optimism
} 
capturados nas suas decisões e, assim, provocar efeitos maléficos no contexto que ele se insere.

Peterson (2000) comenta que, nos Estados Unidos, os maiores objetivos da coletividade incluem escolhas e direitos individuais, como também, a realização individual. Segundo o autor, os estadunidenses estão muito ocupados com o que eles podem e não podem fazer na sua vida quotidiana e, em particular, o que eles podem adquirir. Nessa situação, em uma sociedade capitalista, a aquisição de bens materiais pelos indivíduos e o seu fascínio com o dinheiro lhes permite representar uma forma socialmente admitida de satisfazer a força otimista que organiza toda a cultura. Entretanto, a desvantagem desse modo é o incentivo à ganância (PETERSON, 2000).

Shiller (2000), ao explicar o processo de formação de bolhas no mercado, confirma a participação de alguns fatores psicológicos, dentre os quais o otimismo, o que corrobora com a ideia de que esses fatores afetam as crenças dos indivíduos o que gera como consequência, nesse caso, alterações no comportamento do investimento.

\subsubsection{Formas de Avaliação do Viés Otimista}

Com relação à estimativa do viés otimista, uma maneira simples toma por base a comparação entre o que os indivíduos esperam para si e o que eles acreditam que possa acontecer para os outros.

De acordo Shepperd et al. (2013), o otimismo irrealista, como é chamado o viés, é classificado em dois grupos: a) Absoluto e b) Comparativo, os quais podem ser expressos tanto em nível individual como grupal. Esses tipos de otimismo se diferenciam quanto à forma de medição, prevalência, causas, determinantes situacionais e consequências. Contudo, Armor e Taylor (1998) chamam a atenção que esses quatro critérios nem sempre produzem os mesmos resultados. Assim, pode acontecer de um indivíduo ser otimista quando é avaliado por um critério, e deixar de ser, caso venha a ser avaliado de outra maneira.

Para Shepperd et al. (2013), o otimismo não realístico absoluto ocorre quando o indivíduo fornece uma estimativa absoluta dos riscos pessoais, mais baixa que aquela indicada pelo padrão objetivo. Dessa forma, os resultados negativos individuais têm uma probabilidade de ocorrência menor que a objetivamente estipulada (SHEPPERD et al., 2013). Contudo, esses autores comentam que o desafio para esta forma de medição está na busca do que se considera o padrão objetivo, o qual determina a exatidão das crenças dos riscos. Essa questão é corroborada pela literatura e, nesse sentido, em função das dificuldades relacionadas à 
avaliação dos riscos absolutos, a análise comparativa é a mais adequada (COELHO, 2012; FIFE-SCAW; BARNETT, 2008).

Ao se avaliar, de forma comparativa, existem duas abordagens para se operacionalizar a estimativa dos riscos associados aos eventos futuros: direta e indireta. O método direto é aquele no qual o indivíduo estima seu próprio risco e o compara em relação a um indivíduo médio, através de uma escala única. Na forma indireta, a avaliação do risco acontece em duas escalas separadas, dessa forma, os participantes da pesquisa fornecem a taxa de probabilidade de que eles irão experimentar o evento, como também, a taxa de probabilidade da pessoa média (de igual sexo e idade).

A forma indireta de avaliação apresenta vantagem em função de tornar-se mais informativa à medida que identifica como o fator moderador afeta as crenças otimistas. Outro benefício é que essa avaliação é considerada mais estável e assim aumenta o nível de confiabilidade (HELWEG-LARSEN; SHEPPERD, 2001). Apesar das vantagens, Fife-Schaw e Barnett (2008) alertam que é difícil verificar se as mudanças observadas nos níveis do viés otimista decorrentes de alguma manipulação são atribuíveis ao próprio risco ou ao risco de outro indivíduo.

Com relação à forma de divulgação do otimismo não realístico absoluto (individual ou em grupo), se expresso em nível individual, evidencia uma estimativa menor de risco pessoal quando comparado a outro indivíduo ou a algum padrão de risco disponível. O otimismo não realístico absoluto, em nível de grupo, ocorre quando a média das estimativas dos riscos oferecidas por um grupo de pessoas é mais baixa do que o padrão objetivo de nível do grupo.

Quanto ao otimismo não realístico comparativo, em nível individual, esse otimismo acontece quando uma pessoa fornece uma estimativa comparativa de risco mais baixa que a indicada por um padrão apropriado. Ou seja, isso ocorre quando um indivíduo julgar o seu risco abaixo daquele proposto para um indivíduo médio, ainda que a avaliação dos riscos, individualizada, seja validada por algum calculador de riscos que indique um risco acima da média. O otimismo não realístico comparativo, em nível de grupo, refere-se a situações em que os indivíduos fornecem estimativas nas quais a probabilidade de experimentar resultados negativos, quando comparados aos outros indivíduos, é menor que a média, ao passo que, para os resultados positivos a probabilidade, apresenta-se acima da média quando comparada a de seus pares (SHEPPERD et al., 2013).

No que diz respeito às dificuldades do nível de análise, se individual ou em grupo, os estudos têm revelado que, para ambos os níveis, tem sido difícil saber se um indivíduo está sendo um otimista realista ou um pessimista, além de que, não há informações suficientes dos 
fatores de risco associados a uma pessoa média. Assim, em função dessas implicações, os pesquisadores têm determinado o viés em nível de grupo (FIFE-SCAW; BARNETT, 2008; HARRIS; HAHN, 2011). Além das métricas acima apresentadas em relação ao viés otimista, constata-se que, ao decidir fazer uso de uma delas, não significa necessariamente que o viés fosse observado ao se fazer uso de outra forma de medição. No entanto, uma vez identificado o viés, é possível analisar quais os fatores que moderam o seu grau.

\subsubsection{Fatores Moderadores do Viés Otimista}

Weinstein (1987) verificou, em seus estudos, que o viés otimista está associado com a crença, muitas vezes incorreta, de que se o problema ainda não ocorreu, as chances de ele aparecer no futuro são menos prováveis. Dessa forma, Weinstein (1987) acredita que vieses otimistas aumentam com a evitabilidade percebida de um perigo e diminuem com freqüência percebida e experiência pessoal.

Helweg-Larsen e Shepperd (2001) identificam, em suas pesquisas, fatores pessoais e motivacionais que influenciam o viés otimista. Apesar de ainda não estar claro se o impacto desses afeta a estimativa de risco pessoal ou a estimativa de risco do alvo de comparação, foi possível verificar para os moderadores controle percebido e experiência prévia do viés otimista que eles afetam as estimativas de risco pessoais.

Harris (2007) analisou a manipulação da experiência percebida em eventos negativos da vida pessoal com o intuito de verificar os efeitos na estimativa do próprio risco e de outro indivíduo médio. Os resultados do estudo mostram um aumento para ambas as estimativas no que se refere à facilidade de imaginar um resultado e recordar um acontecimento passado, já para a percepção de controle a manipulação evidencia uma diminuição.

Harris, Griffin e Murray (2008) analisaram o efeito do controle percebido no viés otimista e perceberam um aumento na estimativa de risco próprio quando comparado à estimativa do risco médio.

\subsubsection{Estudos anteriores sobre o Viés Otimista}

Com relação aos trabalhos publicados sobre o viés otimista, as pesquisas versam sobre vários aspectos, como por exemplo, as estimativas de notas em exames que serão realizados no futuro, comparação de previsões pessoais com a experiência posterior, estimativas de salários iniciais avaliadas por estudantes, outros estudos comparam as previsões pessoais para 
eventos como o divórcio, doenças com o álcool e fumo (SHEPPERD et. al. 1996, 2005; DILLARD et al., 2009).

Para Shepperd et al. (2013) os estudos que tratam da estimativa do risco, quanto à pessoa média, tratam dos mais variados eventos como a probabilidade de a pessoa ter um ataque cardíaco fatal, bem como, outros eventos como droga, asma, envenenamento de comida, risco de contrair uma doença sexualmente transmitida, riscos de acidente e catástrofes naturais. Os pesquisadores (2013) explicam que boa parte dos estudos examinados confirma a presença do otimismo exagerado.

Campbell et al. (2007) realizaram uma pesquisa com os estudantes para avaliar o viés otimista em atividades relacionadas à internet, nas questões relativas à segurança e privacidade. Os achados dos autores evidenciam uma tendência exageradamente otimista na estimativa dos eventos.

No estudo realizado por Valerdi e Blackburn (2009), que teve como objetivo principal verificar o otimismo nos engenheiros de computação, verificando técnicas que podem ajudar essa classe de profissionais a gerir melhor o otimismo, contudo, de forma secundária investigaram o otimismo nas mais diversas profissões. Os resultados mostram que a experiência do profissional nem sempre garante o melhor julgamento e, dentro desse contexto, ela pode ser substituída pelo treinamento. Os achados também revelam que profissionais da área contábil, da área de tecnologia de informação, estrategistas e analistas podem ser bastante beneficiados pelo fato de serem menos otimistas, no sentido de que uma boa calibragem pode estar relacionada a um programa de incentivos e prêmios.

Hilary, Hsu e Segal (2013) comentam que boa parte da literatura revela que o excesso de confiança devido a vieses cognitivos pode conduzir a decisões sub-ótimas, os pesquisadores mostram empiricamente que a) o viés otimista está relacionado, contudo difere-se do excesso de confiança, b) emerge de forma dinâmica num quadro racional e não necessariamente por viés cognitivos e c) pode melhorar o bem-estar da empresa. $\mathrm{O}$ estudo revela que os gerentes das empresas que têm experimentado sucessos recentes são mais propensos a emitir previsões mais otimistas do que se não tivessem a presença desse viés e, nesse sentido, exercem um maior esforço para satisfazer as suas previsões demasiado otimistas.

$\mathrm{Na}$ pesquisa realizada por Ucbasaran et al. (2010), os pesquisadores evidenciam os resultados da relação da experiência empresarial e o viés otimista. Os achados revelam que alguns empresários que inicialmente se mostravam mais otimistas, ao ajustar sua forma de pensar relatam uma perspectiva mais realista do seu negócio, contudo, os empreendedores que já tinham uma experiência com o insucesso empresarial, se mostram menos propensos a 
relatar um excesso de otimismo, mas também, observa-se que esse acúmulo de experiência pode conduzir ao viés otimista.

O viés cognitivo da superioridade ilusória também pode causar influência no desempenho, à medida que os indivíduos superestimam suas próprias qualidades e habilidades, em relação aos outros. No estudo realizado por Sveson (1981), os indivíduos foram questionados sobre a sua competência como condutor em relação a um grupo de motoristas. Os resultados mostraram uma forte tendência dos participantes da pesquisa de se considerarem mais habilidosos e com comportamento menos arriscado quando comparados aos demais motoristas de uma forma geral.

Svenson (1981) comenta sobre os achados de estudos semelhantes que foram realizados em outras áreas e que corroboram com seu resultado, bem como, a relação com o viés otimista. Ao se referir sobre a pesquisa de Larwood e Whittaker, em 1977, observa que os estudantes de gestão ao apresentar o viés de auto-serviço da sua própria competência promovem um planejamento excessivamente otimista e arriscado com relação ao futuro. Dessa forma, conclui Svenson (1981) que a crença do indivíduo no que se refere às suas habilidades faz com que tenha comportamento com tendência a serem mais arriscados.

\subsection{A EVIDENCIAÇÃO CONTÁBIL: ATIVOS E PASSIVOS CONTIGENTES}

\subsubsection{A importância da Evidenciação Contábil}

Para que a contabilidade cumpra seu objetivo, que é de fornecer ao usuário informações que possam ser utilizadas pelo mesmo, se faz necessário que ela reconheça, mensure e evidencie as informações produzidas. Neste contexto, merece atenção o fato de que não seja confundido o objetivo da Contabilidade com a evidenciação de suas informações. $\mathrm{Na}$ verdade, a evidenciação é melhor entendida como uma forma de se atingir este objetivo e não ficar restrita a ele.

Dada a gama de interessados na informação contábil, pode-se encontrar usuários internos e externos: funcionários; clientes; administradores; investidores; dentre outros. Devese ressaltar que cada um desses possui interesses distintos e precisam ter suas necessidades satisfeitas, de forma que, algumas vezes uma informação genérica não satisfaz a todos da mesma forma, dado principalmente à dificuldade de se identificar o que é relevante, devendo assim, se possível, serem fornecidas informações específicas (CPC, 2011). 
Evidenciação é um tema bastante amplo, principalmente quanto a como deve ser evidenciado e para quê. Moonitz (1961) cita que os relatórios contábeis têm a função de divulgar o necessário para que não sejam enganosos, no entanto, essa é uma opinião preliminar sobre o assunto, sabendo-se que a divulgação de informação contábil tem sido focada como uma forma de aumentar a transparência e a confiabilidade das empresas, fazendo com que a informação contábil passe a ser valorizada e remunerada pelos agentes envolvidos.

Desta forma, o acesso à informação parte do cenário de uma maior transparência com relação à empresa, onde se aumentaria o número de variáveis a serem incluídas na análise, já que maiores detalhes ficariam expostos ao público, cumprindo a ideia de que toda a informação deve ser pública.

Considera-se que a preocupação com a disponibilização de informações, é justamente dada a perspectiva dos benefícios esperados, de forma que o custo sacrificado para elaborar e tornar acessível às informações são menores que os benefícios angariados com essa ação.

No que se refere às demonstrações contábeis, o CPC 00-R1 (CPC, 2011) diz que elas são elaboradas e apresentadas para usuários externos em geral, tendo em vista suas finalidades distintas e necessidades diversas. Dessa forma, governos, órgãos reguladores ou autoridades tributárias podem determinar suas exigências com o intuito de atender a seus próprios interesses, contudo, sem afetar as demonstrações.

Verrecchia (2001) ao dissertar sobre a teoria da divulgação tem como foco explicar o efeito da divulgação de informações financeiras, procurando identificar quais as suas diversas implicações. Destaca a Pesquisa sobre Divulgação Baseada em Associação (estudo da Associação entre a divulgação e as mudanças no comportamento após o recebimento, neste caso, a informação já foi divulgada), Pesquisa sobre Divulgação Baseada em Julgamento (identifica os motivos que levaram a divulgação de determinadas informações) e Pesquisa sobre Divulgação Baseada em Eficiência (estudam as preferências de divulgação antes que qualquer divulgação dentro da mesma linha tenha sido realizada).

No que se refere ao modelo baseado em Julgamento que o foco da pesquisa aqui construída, Verrecchia (2001) parte da análise de como os gestores e as empresas tratam a divulgação da informação sobre as quais eles têm conhecimento. Salotti e Yamamoto (2005) ao discorrerem sobre o estudo de Verrecchia explicam que esse modelo de divulgação é um processo endógeno, pois, além de examinar sobre as informações divulgadas pelos gestores e/ou empresas, também são considerados os incentivos que estão por trás da motivação à divulgação. 
O fornecimento de informações foi destacado por Salotti e Yamamoto (2005) como uma forma de evitar a seleção adversa, de forma que destacam que os usuários da informação contábil costumam reagir de forma negativa quando alguma informação não é publicada, no sentido de que a informação que por ventura esperava-se ser publicada e que não o foi, passa a ser encarada pelo usuário como algo ruim, pois imagina-se que a empresa esteja escondendo algo prejudicial a sua continuidade, assim, esse caráter negativo seria diminuído pelo aumento da divulgação.

Dye (2001), ao expor suas críticas em relação aos estudos de Verrecchia, esclarece que sua crença com relação à divulgação das informações está centrada na ideia de que os gestores e as empresas farão as divulgações de acordo com o nível de favorecimento conquistado pela informação publicada. Ou seja, se divulgar informações positivas em um momento faz com que a empresa aumente o seu valor ela será divulgada, do contrário também é verdadeiro, se uma informação apesar de negativa, em determinado momento for favorável senão à empresa, mas para o gestor ela também será divulgada.

Assim, a divulgação de informações contábeis pela firma pode, também, mitigar o problema de seleção adversa e da assimetria informacional, nivelando o campo de jogo entre os usuários da informação contábil (VERRECCHIA, 2001). No contexto dos passivos contingentes, Salotti e Yamamoto (2005) chamam a atenção para o problema da seleção adversa. Nesse caso, os autores recomendam que análise dos efeitos da não divulgação desses eventos deve ser feita com o intuito de identificar o que essa ausência irá causar nos usuários da informação.

Salotti e Yamamoto (2005) ao estabelecerem uma análise do modelo de divulgação por julgamento e as escolhas dos gerentes quanto à informação privada, partem da suposição de que ela seja feita de forma confiável, no entanto, essa confiabilidade se justifica pela possibilidade de ocorrência de algum litígio e custos de erosão do capital humano associados com a dissimulação. Contudo, os autores alertam que existem situações, e cita como exemplo a provisão para contingências, onde se torna complexo e dificultoso avaliar a integridade da divulgação do gestor.

\subsubsection{Ativos e Passivos Contingentes}

O termo "contingente" refere-se a eventos fortuitos, incertos em relação à sua ocorrência. É usado para passivos e ativos “[...] que não sejam reconhecidos porque a sua existência somente será confirmada pela ocorrência ou não de um ou mais eventos futuros 
incertos não totalmente sob o controle da entidade" (CPC 25, p. 6, 2009). Enquanto a contingência relaciona a existência de ativos e passivos à possibilidade de ocorrência de eventos futuros e incertos, a subjetividade permite opinar acerca dessa incerteza. Contudo, o que é certo em se tratando das contingências é que o resultado das avaliações sobre os aspectos que as envolvem impacta no processo de reconhecimento, mensuração e na forma de evidenciação das informações contábeis.

De acordo com as definições apresentadas no Pronunciamento Técnico 25 do CPC (CPC, p. 5, 2009) um Passivo contingente é:

(a) uma obrigação possível que resulta de eventos passados e cuja existência será confirmada apenas pela ocorrência ou não de um ou mais eventos futuros incertos não totalmente sob controle da entidade; ou

(b) uma obrigação presente que resulta de eventos passados, mas que não é reconhecida porque: (i) não é provável que uma saída de recursos que incorporam benefícios econômicos seja exigida para liquidar a obrigação; ou (ii) o valor da obrigação não pode ser mensurado com suficiente confiabilidade.

Dentro desse contexto, o pronunciamento diz que, para se reconhecer um passivo, é necessário haver não somente uma obrigação presente, mas também a probabilidade de saída de recursos que incorporam benefícios econômicos para liquidar essa obrigação. O CPC 25 considera como provável essa saída de recursos se a probabilidade da ocorrência do evento for maior do que a probabilidade de isso não acontecer. Nesse contexto, o IAS 37 (IASB, 2012) descrevem que "o evento que cria uma obrigação legal ou presumida; é justamente da obrigação presumida que deriva as condutas e práticas que introduzem o subjetivismo no reconhecimento das provisões". (tradução nossa).

No que tange às provisões, observa-se no quadro 2 as recomendações descritas no CPC 25. Assim sendo, elas são reconhecidas como passivo à medida que são representadas por obrigações presentes com provável saída de recursos e incorporação de benefícios econômicos. Contudo, quando há obrigação presente que requer saídas de recursos essa provisão deve ser reconhecida e divulgada. 
Quadro 2 - Provisão x Passivo Contingente

\begin{tabular}{|l|l|l|}
\hline \multicolumn{2}{|l|}{$\begin{array}{l}\text { São caracterizados em situações nas quais, como resultado de eventos passados, pode haver uma saída de } \\
\text { recursos envolvendo benefícios econômicos futuros na liquidação de: (a) obrigação presente; ou (b) } \\
\text { obrigação possível cuja existência será confirmada apenas pela ocorrência ou não de um ou mais eventos } \\
\text { futuros incertos não totalmente sob controle da entidade. }\end{array}$} \\
\hline $\begin{array}{l}\text { Há obrigação presente que } \\
\text { provavelmente requer uma saída } \\
\text { de recursos. }\end{array}$ & $\begin{array}{l}\text { Há obrigação possível ou } \\
\text { obrigação presente que pode } \\
\text { requerer, mas provavelmente } \\
\text { não irá requerer, uma saída de } \\
\text { recursos. }\end{array}$ & $\begin{array}{l}\text { Há obrigação possível ou } \\
\text { obrigação presente cuja } \\
\text { probabilidade de uma saída de } \\
\text { recursos é remota. }\end{array}$ \\
\hline A provisão é reconhecida & $\begin{array}{l}\text { Nenhuma provisão é } \\
\text { reconhecida }\end{array}$ & $\begin{array}{l}\text { Nenhuma provisão é } \\
\text { reconhecida }\end{array}$ \\
\hline $\begin{array}{l}\text { Divulgação é exigida para a } \\
\text { provisão }\end{array}$ & $\begin{array}{l}\text { Divulgação é exigida para o } \\
\text { passivo contingente }\end{array}$ & Nenhuma divulgação é exigida \\
\hline
\end{tabular}

Fonte: CPC 25

No tocante aos ativos contingentes, da mesma forma, é válida a premissa de que se for praticamente certa a entrada de benefícios econômicos, o ativo deve ser reconhecido nas demonstrações contábeis. Ao se referir ao Ativo contingente, o CPC 25 (CPC, p.5, 2009) o descreve como sendo "um ativo possível que resulta de eventos passados e cuja existência será confirmada apenas pela ocorrência ou não de um ou mais eventos futuros incertos não totalmente sob controle da entidade".

Quanto ao reconhecimento dos ativos contingentes nas demonstrações financeiras, o CPC 25 (2009) institui que sendo praticamente certa a realização do ganho, esse ativo terá seu adequado reconhecimento, não sendo, portanto, classificado como um contingente, contudo, estabelece o não reconhecimento desse ativo quando se referir a um resultado que nunca venha a ser realizado. No tocante à divulgação, se for provável a entrada de benefícios econômicos o mesmo deve ser publicado.

No que se refere às demonstrações contábeis, Antunes et al., (2012) comentam que essas devem ser ajustadas, no que se refere à forma da informação a ser divulgada, conforme o perfil do usuário e sua aversão aos riscos e, sendo assim, ao relacionar aos contingentes exemplificam que no caso de um investidor arrojado poder-se-ia ajustar as demonstrações contábeis, levando em conta os ativos contingentes que não foram reconhecidos, mas que estão evidenciados em notas explicativas. No entanto, para um investidor conservador os ajustes iriam tratar os passivos contingentes como efetivamente não reconhecidos, e assim estariam aumentando a segurança quanto aos riscos envolvidos em um investimento.

No que tange à divulgação das provisões contingentes, o quadro 3 mostra que os elementos se diferenciam em dois grupos (quantitativos) dizem respeito às informações que devem ser divulgadas quanto ao reconhecimento nas demonstrações contábeis e com relação àquelas a serem mencionadas nas notas explicativas, deve haver uma clara descrição da 
natureza da obrigação, bem como a indicação das incertezas. Quanto mais detalhadas forem essas informações, mais transparentes elas se tornam aos usuários.

Quadro 3 - Divulgação de Informações de Provisões

Valor contábil no início e no fim do período;

Provisões adicionais feitas no período, incluindo aumentos nas provisões existentes;

Valores utilizados (ou seja, incorridos e baixados contra a provisão) durante o período;

Valores não utilizados revertidos durante o período;

Aumento durante o período no valor descontado a valor presente proveniente da passagem do tempo e o

efeito de qualquer mudança na taxa de desconto

Breve descrição da natureza da obrigação e o cronograma esperado de quaisquer saídas de benefícios econômicos resultantes;

Indicação das incertezas sobre o valor ou o cronograma dessas saídas;

Valor de qualquer reembolso esperado.

Fonte: (CPC 25, 2009)

Darabi e Faghoni (2012) destacam, em suas pesquisas, a importância da informação dos passivos contingentes, bem como de seus tipos, os quais produzem diferentes efeitos, ou seja, o foco não está apenas na informação do passivo contingente que está sendo considerado, mas também no tipo e valor de tais passivos. Os autores comentam que diferentes grupos de usuários de informações financeiras, tais como os corretores da bolsa, especialistas em investimentos e professores universitários têm diferentes prioridades e interesses para fazer o investimento em uma empresa tomando como base sua situação financeira. Sendo assim, a divulgação de quaisquer passivos contingentes, afetaria de forma diferente a sua tomada de decisão.

Suave et al. (2013) propõem verificar se as empresas mais negociadas da BM\&FBOVESPA atendem às disposições do CPC 25 quanto à divulgação de passivos contingentes. Os resultados da pesquisa revelam que as empresas divulgam, principalmente, processos judiciais relacionadas a causas fiscais, cíveis e trabalhistas, com menor divulgação às de contingências ambientais.

Ribeiro (2012) constata, em sua pesquisa, que a emissão do CPC 25 fez com que as empresas aumentassem a evidenciação de ativos e passivos contingentes, bem como das provisões. O autor observa que as provisões originadas por demandas administrativas e judiciais são mais suscetíveis à manipulação em função da subjetividade existente no processo de compreensão da legislação e o impacto no resultado contábil. Ou seja, devido ao complexo sistema tributário nacional, existe a possibilidade de se fazer o gerenciamento de resultados via constituição ou não de provisões. 
Ribeiro, Ribeiro, Weffort (2013) tinham como objetivo do estudo verificar as percepções dos profissionais envolvidos no que se refere às provisões. Os resultados da pesquisa revelam que os advogados e auditores sinalizam uma preocupação com a subjetividade presente nas instituições delas, como também a complexidade das leis e altos valores envolvidos. Nas entrevistas realizadas pelos autores, os auditores comentam que a complexidade da legislação contribui para a subjetividade nas provisões, como também reduz a assimetria da informação ao divulgar as contingências em notas explicativas, eliminando erros de julgamentos e aumentando a transparência da informação aos usuários.

Na pesquisa realizada por Machado et al (2015), os resultados revelam que a adoção do CPC 25 reduziu o nível de conservadorismo. Os autores, ao estabelecerem uma comparação da variação das provisões entre os balanços conservadores e não conservadores verificaram a existência de diferença estatística entre as variações. Ou seja, a pesquisa mostra que as provisões são maiores em empresas que apresentam balanços conservadores.

\subsection{A INFORMAÇÃO CONTÁBIL NO CONTEXTO DO CONSERVADORISMO E NEUTRALIDADE}

Bliss (1924, apud WATTS, 2003) expressa o conservadorismo de modo que não se antecipa nenhum lucro, contudo, no caso das perdas, devem-se antecipar todas elas. Dentro dessa ótica, Basu (1997) interpreta o conservadorismo como sendo uma tendência dos contadores de exercer um maior controle das boas notícias para o reconhecimento dos ganhos do que das más notícias como perdas. Dessa forma, percebe-se uma assimetria entre o reconhecimento de ganhos e perdas sendo assim possível verificar os graus de conservadorismo. Basu (1997) comenta que quanto maior a diferença no grau de verificação entre ganhos e perdas, maior o conservadorismo. Watts (2003) define o conservadorismo sob a ótica do reconhecimento dos lucros e perdas, no sentido de antecipar todas as perdas e nenhum lucro.

Basu (1997) há mais de 20 anos já alertava que a prática contábil tornou-se ainda mais conservadora. Sua interpretação parte dos resultados das pesquisas empíricas que tratam desse enfoque. Uma possível explicação da longa permanência do conservadorimo é que seus críticos ignoram seus benefícios sem a devida compreensão e, em função disso, pode haver danos para os relatórios financeiros. Basu (1997) explica que os pesquisadores acreditam que o conservadorismo beneficia os usuários de relatórios contábeis da empresa. 
Para Dickhaut (2009) as empresas optaram por uma contabilidade mais conservadora antes mesmo que fossem estabelecidos os padrões formais de práticas contábeis. Dessa forma, ele sugere que o conservadorismo parte de operações repetidas e assim acaba por regular o comportamento entre as organizações.

Basu (1997) ao se referir às explicações das origens e influências do conservadorismo descreve a ligação dos ganhos da empresa e o sistema de compensação dos gerentes. Nesse contexto, é de se esperar que sejam retidas as más notícias que possam afetar negativamente o lucro. Dessa forma, ele influencia as políticas de remuneração dos gestores. Watts (2003) comenta que o conservadorismo inibe um comportamento oportunista por parte do gestor, à medida que o adiamento dos ganhos e a subestimação dos lucros e ativos líquidos têm como efeito no contrato o aumento do valor da empresa, e esse é compartilhado entre todas as partes da empresa, aumentando o bem-estar.

Basu (1997) descreve que as forças reguladoras também justificam a manutenção e importância do conservadorismo. Para Watts (2003) as ações judiciais de acionistas, a regulamentação fiscal e a contabilidade são explicações que também ajudam a compreender a sobrevivência do conservadorismo, além do gerenciamento de resultados, embora esse não seja a principal justificativa.

Toda informação contábil divulgada tem como escopo contribuir para o processo decisório de vários usuários, de tal forma que preserve os atributos e evite que essa informação cause favorecimento de grupos específicos.

Dentre as qualidades da informação contábil pode-se dizer que a relevância e a representação fiel são características imprescindíveis e que carregam as demais características, como a comparabilidade, verificabilidade, tempestividade e compreensibilidade (CPC 00-R1, 2011). Esses últimos atributos se relacionam muito mais no sentido de melhorar a qualidade, os dois primeiros determinam as características qualitativas fundamentais conforme o IAS 37 (IASB, 2012). A relevância trata da utilidade da informação contábil na elaboração de projeções futuras. Refere-se ao seu valor preditivo, capaz de fazer a diferença no processo decisório.

Ao se discutir sobre o significado de representação fidedigna da realidade, observa-se que de acordo com o CPC 00-R1, emitido pelo Comitê de Pronunciamento Contábeis (CPC, 2011), as normas se referem a uma demonstração completa, neutra e livre de erros (CPC, 2011). Logo, é necessário que a demonstração esteja a mais próxima possível da realidade econômica. De igual importância, a obtenção das informações de movimentação e alteração 
dessa realidade, pois isso ajuda a melhorar a visão sobre o futuro (REPRESENTAÇÃO, 2013).

No que tange à informação contábil-financeira, elas estão divididas em dois grupos: 1- características qualitativas fundamentais e 2- características qualitativas de melhoria. Segundo a estrutura conceitual (CPC 00-R1, 2011), o primeiro grupo se refere aos atributos mais determinantes, como a relevância e representação fidedigna, ao passo que, no segundo grupo, encontram-se os predicados menos críticos como comparabilidade, verificabilidade, tempestividade e compreensibilidade. Esse pronunciamento, em termos de mudanças, esclarece que a confiabilidade foi redenominada como representação fidedigna e a prudência (conservadorismo) foi retirada dessa condição por ser inconsistente com a neutralidade. Para Antunes et al. (2012) essas mudanças buscam o aprimoramento da qualidade da informação contábil, objetivando a utilidade da informação para o seu usuário.

Com relação à prudência, embora tenha sido removida da estrutura conceitual em vigor a partir de 2010, essa característica foi reintroduzida em 2015 através de um Exposure Draft (ED) publicado pelo IASB. A proposta se refere como um aspecto dentre as características que contribuem na utilidade das demonstrações financeiras. O IASB reconhece que a ambiguidade contida na definição do termo do que é prudência antes de 2010, tenha sido o maior entrave para a sua aplicação, pois da forma como estava expressa conduzia a um viés conservador nos relatórios emitidos, impactando também na questão da neutralidade.

O pronunciamento do CPC 00-R1 (CPC, 2011), ao se referir à utilidade da informação financeira, descreve que ela não tem só que representar um fenômeno relevante, mas tem também que representar com fidedignidade esse fenômeno. Dessa forma, a realidade a ser retratada tem que ser completa neutra e livre de erro.

Sobre a neutralidade, o CPC 00-R1 (CPC, 2011) diz que

\begin{abstract}
Um retrato neutro da realidade econômica é desprovido de viés na seleção ou na apresentação da informação contábil-financeira. Um retrato neutro não deve ser distorcido com contornos que possa receber dando a ele maior ou menor peso, ênfase maior ou menor, ou qualquer outro tipo de manipulação que aumente a probabilidade de a informação contábil-financeira ser recebida pelos seus usuários de modo favorável ou desfavorável. Informação neutra não significa informação sem propósito ou sem influência no comportamento dos usuários. A bem da verdade, informação contábil-financeira relevante, por definição, é aquela capaz de fazer diferença nas decisões tomadas pelos usuários.
\end{abstract}

Ainda nesse contexto, vale ressaltar que o IASB considera importante discutir a definiçao do que engloba o termo prudência. A definição apresentada no ED (2015) trata da neutralidade sendo suportada pelo exercício da prudência, onde a prudência se refere ao 
cuidado de se fazer julgamentos em condições de incerteza. $\mathrm{O}$ exercício de prudência não deve permitir a subavaliação de ativos e rendimentos ou sobreavaliação de passivos e despesas. Ou seja, por essa definição, uma cautelosa prudência também garante a neutralidade das informações produzidas.

Enquanto o conservadorismo nos conduz, quanto ao registro dos fatos, a um comportamento no sentido de antecipar as perdas e diferir o reconhecimento dos ganhos, a neutralidade recomenda, na medida do possível, uma mensuração com o mínimo de afastamento do valor verdadeiro. Nesse contexto, são percebidas contradições quanto ao procedimento de mensuração. Pela ótica do conservadorismo, se a antecipação das perdas e a postergação dos ganhos concebem a melhor "representação" da realidade é assim que deve ser precedida a avaliação. Contudo, pode não ser essa a melhor representação fidedigna do fenômeno econômico ao se estabelecer a relação com a neutralidade, a qual não seja direcionada a um resultado pré-determinado.

Analisando-se o conservadorismo com a produção de uma informação contábil influenciada pelo otimismo exacerbado, no contexto dos itens contingentes, é possível que o indíviduo com perfil conservador tente evitar superestimar a ocorrência de ativos contingentes e subestimar os passivos contingentes, contudo, existe o risco de ocorrer por conta da presença desse viés, e se assim fosse teríamos uma contrariedade em relação as duas óticas acima descritas. O IASB (2015) comenta sobre a importância de a gestão não preparar demonstrações financeiras com viés otimista, pois, ao escolher estimativas que estão constante e exageradamente otimistas, é improvável resultarem demonstrações financeiras que representem, fielmente, o negócio.

Para que a contabilidade possa ser utilizada como um instrumento de redução de assimetria informacional, é condição necessária para as informações contidas nas demonstrações contábeis que elas sejam confiáveis, compreensíveis, comparáveis e relevantes e assim possam servir aos usuários externos à empresa (ANTUNES et al., 2012). Ainda nesse contexto, o IFRS (2013) descreve que as características qualitativas é que identificam os tipos de informação de maior utilidade aos diversos usuários tomarem as decisões sobre a entidade (IFRS, 2013).

\subsection{SOBRE AS VARIÁVEIS DE CONTROLE}

Para Martin, Santos e Dias Filho (2004), uma entidade empresarial durante o desenvolvimento de suas atividades está exposta a uma série de riscos e, nesse contexto, é 
imprescindível conhecê-los até mesmo para saber como manter um adequado gerenciamento sobre eles. Com o intuito de se estabelecer controles adequados sobre eles, esses riscos podem ser organizados de acordo com a área a qual pertencem (riscos de propriedade, de processo e comportamentais).

De acordo com Martin, Santos e Dias Filho (2004, p.5) "os riscos comportamentais são os riscos vinculados à aquisição, manutenção, utilização e disposição dos ativos empresariais de base humana, entre as quais se encontra a capacidade de gestão". Nesse grupo estão incluídos os riscos decorrentes da insatisfação ou desmotivação dos colaboradores, relacionados com a disfuncionalidade dos ambientes de trabalho, bem como, os riscos de percepção e julgamento.

Sobre a motivação Todorov e Moreira (2005) ao tentarem dissecar o termo proposto por Bergamini em 1997, explicam que, num primeiro momento, ela se encontra dentro do indivíduo e num segundo momento depende de situações específicas, contudo, ao longo de suas explicações observam que a motivação não ocorre de fora para dentro e sim de dentro para fora, neste sentido, revelam que o que deve ser feito é buscar por situações específicas que visam a motivar os indivíduos ou ao menos não desmotivá-los. Os riscos de percepção e julgamento se originam a partir das atitudes, percepções e valores que prevalecem em grupos influentes internos, como a alta direção e, em decorrência desses fatores, os indivíduos podem ser levados a tomar decisões e apresentar comportamentos negativos em relação à empresa e aos stakeholders, o que expõe a empresa a outros riscos (MARTIN, SANTOS, DIAS FILHOS, 2004). Vale salientar que o fator comportamental pode conduzir a uma tomada de decisões enviesadas em decorrência dessas questões ora apresentadas.

A possibilidade da presença de otimismo exagerado no julgamento do preparador da informação contábil pode advir de várias fontes, como por exemplo, da gerência que assim impõe uma visão irreal do mundo, como também, do ambiente, além de que, a própria norma permite uma liberdade maior para que o preparador decida de maneira mais objetiva. O que é certo é que as consequências dessa decisão podem ser percebidas no produto oferecido pela contabilidade: a informação e sua evidenciação.

Com base no que foi exposto anteriormente é possível que o preparador das informações contábeis receba influências no processo de julgamento das estimativas de probabilidades de eventos contingentes, especialmente, ao se analisar o contexto no qual abrange a sua independência na condução das atividades, bem como, outros aspectos associados ao ambiente e à estrutura organizacional, como o uso de informações externas no processo de julgamento e a subordinação de funções. 
O CPC 25 expõe que as estimativas do desfecho e do efeito financeiro são determinadas pelo julgamento da administração da entidade, complementado pela experiência de transações semelhantes e, em alguns casos, por relatórios de peritos independentes.

As estimativas de probabilidade são determinadas pelo julgamento da administração, contudo, para fins dessa análise pode-se fazer uso de experiências advindas de eventos semelhantes. A ideia subjacente do CPC 25 é a que se deve aplicar a analogia e, assim, garantir a manutenção de um julgamento adequado à situação, da mesma forma, o uso de relatórios adicionais também contribui para a avaliação de ponderações equilibradas. No entanto, pode-se interpretar que ao se fazer uso de informações adicionais compartilha-se responsabilidades em relação ao julgamento, tendo como possível consequência uma alteração da estimativa anteriormente estabelecida.

O CPC 25 determina que o julgamento das avaliações de probabilidade seja da administração da entidade, mas, como se observa, ele permite complementar sua decisão com informações advindas de peritos independentes, nesse caso pode-se fazer uso de profissionais como auditores e advogados. Por outro lado, sabe-se que o contador é quem vai elaborar as informações a serem divulgadas, cabendo a ele e ao gestor a responsabilidade de responder, civil e penalmente, pelas demonstrações contábeis produzidas. Assim, é de se esperar que haja uma participação do elaborador das informações contábeis e, parece oportuno saber como se dá essa participação, se ela é relevante ou não das informações contábeis nesse processo.

Em se tratando do comportamento dos contadores, Popa et al. (2011) explicam que parte deles muitas vezes segue seus interesses individuais e assim esbarram na questão da moralidade profissional. Isso se deve ao fato de que os salários e as condições de trabalho dos contabilistas são decididos pelos gestores. Outra razão é o fator subjetivo e objetivo que cria uma lacuna entre a capacidade julgamento dos contadores e do padrão contábil.

Com relação às teorias relacionadas às variáveis de controle constituídas, observa-se que não existe uma teoria única que permeie suas bases. No que diz respeito à forma de contratação subjacente a essa variável está em análise a questão da independência do indivíduo no processo de escolhas e tomada de decisão. Vista sob o ângulo teórico, a independência é discutida na teoria da agência, como também, na temática de controles internos e controladoria.

A variável existência de fiscalização de tarefa traz, como foco, a subordinação de funções, representando uma forma de controle preventivo dentro da temática de controladoria, como também, sob outra ótica se refere ao processo de prestação de contas das atividades desempenhadas dentro da organização. No caso da variável fonte adicional de informação, ela 
se reporta à teoria da agência de Jensen e Meckling, especialmente quando faz referência às discussões sobre os conflitos de interesse entre as partes envolvidas, possibilitando, a ocorrência de práticas de gerenciamento de resultados no que se refere às escolhas de probabilidades dos contingentes.

A literatura evidencia pesquisas que tangenciam, de forma indireta, as variáveis de controle acima descritas. Ribeiro (2012), em seu estudo, fez uso do CPC 25 e teve, como objetivo principal, verificar se houve um aumento de evidenciação após a emissão desse pronunciamento. Como objetivo secundário, explorou a possibilidade de práticas de gerenciamento de resultados. Para isso, faz uso da triangulação de informações advindas de advogados e auditores.

Popa et al. (2011) em suas pesquisas sobre o julgamento profissional dos auditores constata que ele é influenciado pelo seu conhecimento e experiência, bem como, por suas limitações cognitivas. Os autores afirmam que o conhecimento e a capacidade de cada especialista são limitados e, por serem assim, necessitam do auxílio de outros especialistas que certamente contribuem para melhorar o processo de tomada de decisão dos auditores. Ou seja, seu estudo evidencia a importância das interações pessoais como fatores influentes no julgamento profissional dos auditores. 


\section{METODOLOGIA}

\subsection{TIPO DE PESQUISA}

Com o intuito de atingir o escopo do presente trabalho, a tipologia de pesquisa a ser utilizada refere-se a um quase-experimento. Esse método pode ser visto com um experimento, que tem um objetivo a alcançar, se diferenciando na característica da aleatoriedade. De acordo com Shadish, Cook e Campbell (2002), o experimento trata de um estudo no qual uma intervenção é deliberadamente introduzida para observar os seus efeitos, os autores afirmam que o controle de variáveis é considerado um atributo comum entre os experimentos, como também, outra característica dessa técnica refere-se à atribuição aleatória. Nesse contexto, os autores (2002) comentam acerca da necessidade da aleatoriedade para tornar o quaseexperimento em adequado experimento.

Bandeira (2012, p.1) ao se referir ao método, o define como sendo "delineamentos de pesquisa que não têm distribuição aleatória dos sujeitos pelos tratamentos, nem gruposcontrole". Moore (2008, p.2), ao tratar dessa tipologia, elenca alguns pontos os quais impedem que o estudo seja tratado como um verdadeiro experimento, sendo mais apropriado referir-se a um quase-experimento: a) Dificuldade de atribuição aleatória por não ser possível, ou por ser antiética ou por oposição da comunidade ou do órgão financiador; b) amostra pequena que dificulta a manutenção de grupos de tratamento e controle.

Para os fins desta pesquisa, a justificativa do enquadramento de quase-experimento se deve aos fatos de que a amostra foi formada a partir de uma motivação (o curso gratuito) assim impossibilitou a manutenção da aleatoriedade.

Com relação ao desenho, Moore (2008) comenta que são possíveis vários tipos de representação quase-experimental, contudo, variam amplamente em função do custo e dificuldade inerentes ao objetivo de pesquisa.

\subsection{DESENHO DO EXPERIMENTO}

Para fins de operacionalização dessa pesquisa, esse estudo aconteceu em cinco fases sequenciais: seleção dos participantes da pesquisa; medição do viés otimista e fatores moderadores no indivíduo e outras três fases subsequentes de experimentos isolados. Na primeira fase, seleção dos participantes da pesquisa, formaram-se três subgrupos para verificar os efeitos de variáveis com potencial de influenciar o julgamento das probabilidades. 
$\mathrm{Na}$ segunda fase, procedeu-se à medição do viés otimista no indivíduo e à aferição da influência de fatores moderadores no nível do viés calculado. Nas etapas subsequentes, foram feitos experimentos isolados, nos quais os participantes da pesquisa foram expostos a situações que contemplam características de ativos e passivos contingentes para os quais os indivíduos estimam probabilidades da ocorrência de tais eventos (Figura 1).

Figura 1 - Metodologia cronológica

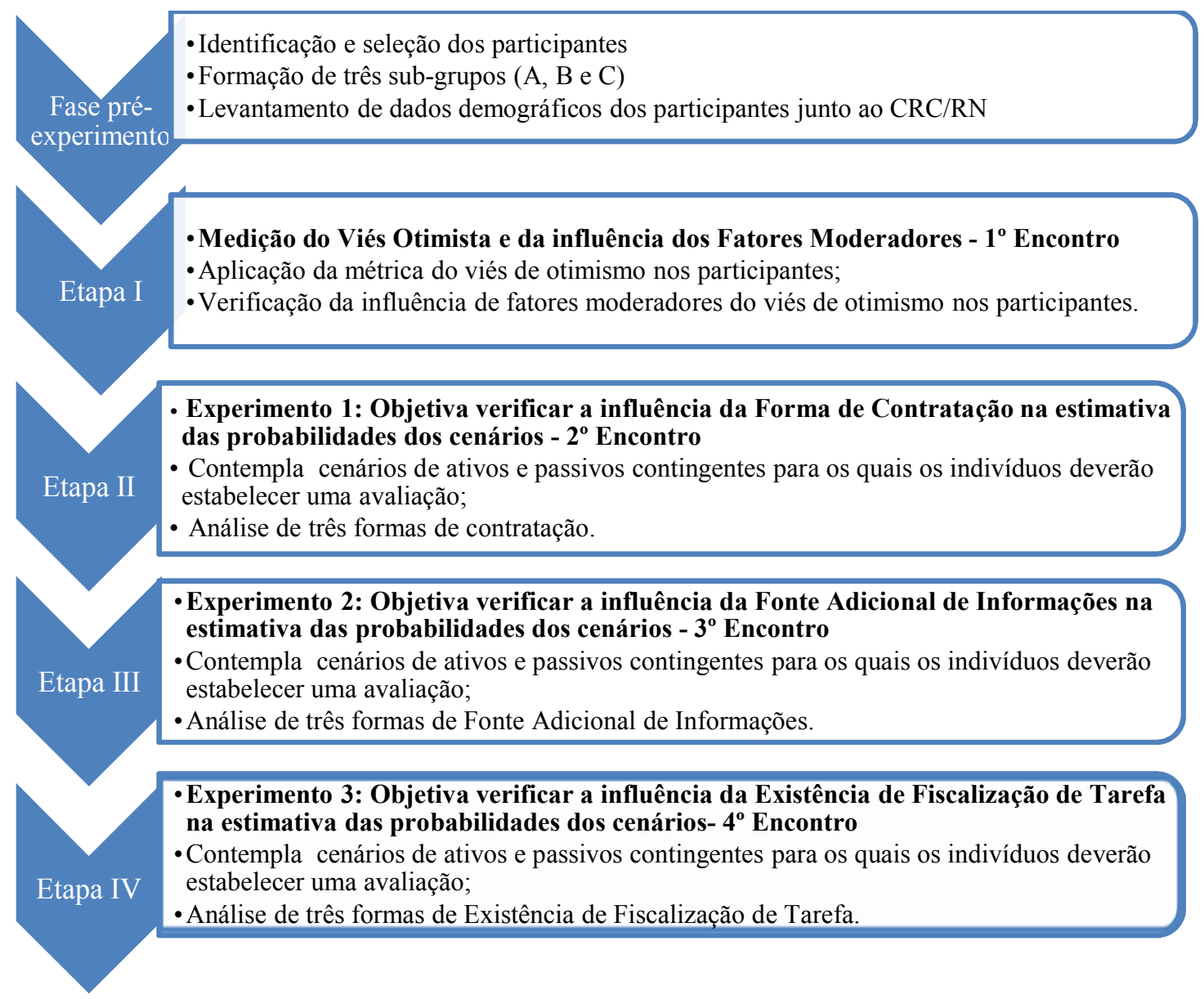

Fonte: Dados da pesquisa, 2016.

Pela figura 1, é possível visualizar os objetivos a serem alcançados em cada etapa, bem como a relação de independência dos três experimentos a serem aplicados. Contudo, a sequência da organização desse estudo permite verificar a interação dos resultados alcançados na etapa I com as demais etapas que tratam das variáveis de controle. 


\subsection{INSTRUMENTO DE COLETA DE DADOS}

\subsubsection{Relacionado à medição do Viés Otimista}

Para a mensuração do viés otimista no indivíduo é necessário determinar algumas classificações relacionadas à sua tipologia. Com relação aos tipos de excesso de otimismo, SHEPPERD et al (2013) mostra quatro tipos, já comentados anteriormente, e que variam a) no padrão de comparação; b) no modo de avaliação e c) no nível de análise. Para os fins dessa pesquisa, é necessário estabelecer a forma de medição do viés, sendo assim, a métrica empregada nessa pesquisa se classifica, quanto ao tipo, em comparativa, com avaliação indireta e em nível grupal, conforme capítulo 2. A escolha da métrica levou em consideração a predominância desse formato nos estudos apresentados pela literatura (SHEPPERD et al, 2013; COELHO, 2012; FIFE-SCAW; BARNETT, 2008, ARMOR;TAYLOR,1998), como também, das dificuldades associadas ao processo de avaliação dos riscos.

A avaliação comparativa, de forma indireta e em nível grupal, tem como objetivo verificar se as probabilidades avaliadas por determinado indivíduo de experimentar eventos futuros na sua vida se diferenciam das probabilidades fornecidas por ele para outro indivíduo médio (SHEPPERD et al, 2013). Dessa forma, são realizadas duas avaliações, em escalas separadas, estimando, primeiro, o risco próprio e, em seguida, o risco de outro indivíduo médio. A definição de indivíduo médio, para os fins desse trabalho, se reporta a uma pessoa que seja do mesmo sexo, idade e condição socioeconômica do participante desta pesquisa.

No questionário, ele incluiu dez eventos, cinco positivos e cinco negativos os quais contemplam a temática "perdas e ganhos financeiros" na vida pessoal. A ordenação dos eventos foi disposta inicialmente pelos eventos positivos seguido dos eventos negativos. Esses eventos são claramente definidos como negativo ou positivo não contendo nenhuma condição prévia ("se”, “então").

Para eventos negativos, a diferença é estabelecida entre a estimativa do próprio risco e a estimativa do risco do indivíduo médio. Para eventos positivos, estabelece-se a diferença entre a estimativa do risco do indivíduo médio e a estimativa do próprio risco, ou seja, o oposto deve ser constituído. O formato do questionário usado nesse estudo é apresentado por Fife-Scaw e Barnett (2008) conforme a descrição abaixo:

a) Questionário de avaliação de risco próprio - “O quanto provável você pensa que cada um dos seguintes eventos pode acontecer na sua vida?"; 
b) Questionário de avaliação de outro indivíduo médio - "Pense um indivíduo médio, de mesmo sexo e idade do respondente, o quanto provável você acha que cada um dos eventos seguintes pode acontecer a essa pessoa no futuro?".

1- A escala de probabilidade para cada evento varia de 0 a 10 conforme o modelo:

\begin{tabular}{|l|l|l|l|l|l|l|l|l|l|l|l|}
\hline Questões & \multicolumn{1}{|c|}{$\begin{array}{l}\text { O evento certamente } \\
\text { não acontecerá }\end{array}$} \\
\hline 1 & 0 & 1 & 2 & 3 & 4 & 5 & 6 & 7 & 8 & 9 & 10 \\
\hline
\end{tabular}

2- A numeração dos eventos segue uma ordem sequencial. Tomando como exemplo a aplicação de dois questionários (avaliação de risco próprio e de risco de um indivíduo médio), contendo 10 eventos, no segundo questionário a primeira questão será a 11, a qual corresponde com a questão 1 do primeiro questionário e assim sucessivamente;

3- O cômputo do viés representa a média da diferença entre os dois questionários anteriormente identificados;

4- $\mathrm{O}$ viés otimista se manifesta quando a média da diferença entre a estimativa do próprio risco e a estimativa do risco do outro indivíduo médio apresentar-se abaixo de zero;

5- Quanto maior a diferença acima descrita maior será o grau de viés otimista;

Uma vez que os participantes avaliaram a probabilidade da ocorrência dos eventos de acordo com as instruções acima, solicitou-se-lhes a avaliação dos fatores moderadores.

A experiência pessoal prévia e a percepção de controle sobre os eventos causam um forte impacto no nível do viés otimista, especialmente, no que se refere à controlabilidade; Helweg-Larsen e Shepperd (2001) descrevem as formas de avaliação utilizadas pelos pesquisadores e as classifica em quatro abordagens. Para fins dessa pesquisa, emprega-se o segundo enfoque, o qual utiliza a pessoa como nível de análise. Sendo assim, o indivíduo fornece a sua taxa em relação à capacidade de controle, bem como a taxa para a pessoa média. Dessa forma, as avaliações são realizadas em escalas separadas, com a seguinte ordem: $1^{\circ}$ avaliação dos moderadores do próprio risco e $2^{\circ}$ avaliação dos moderadores de indivíduo médio. Os questionamentos referentes aos moderadores seguiram o formato abaixo:

a) Questionário de avaliação para a percepção de controle

"O quanto você pensa que tem de controle sobre cada um dos seguintes eventos?"; 
"O quanto você pensa que um indivíduo médio, de mesmo sexo e idade têm de controle sobre cada um dos seguintes eventos?";

b) Questionário de avaliação para a experiência prévia

"Indique o quanto de experiência você tem sobre cada um dos seguintes eventos?";

"Indique quanto você pensa que um indivíduo médio, de mesmo sexo e idade têm de experiência sobre cada um dos seguintes eventos?”

1- A escala de probabilidades para cada evento varia de 0 a 10 conforme o modelo abaixo:

\begin{tabular}{|l|c|c|c|c|c|c|c|c|c|c|c|}
\hline Fator Moderador & 0 & 1 & 2 & 3 & 4 & 5 & 6 & 7 & 8 & 9 & 10 \\
\hline Experiência Pessoal Prévia & \multicolumn{8}{|l|}{$\begin{array}{l}\text { Muita Pouca Experiência } \\
\text { Muito Pouco Controle } \\
\text { Controle do Evento }\end{array}$} \\
\hline
\end{tabular}

2- A influência no nível do viés otimista é verificada a partir das diferenças encontradas entre as avaliações dos fatores moderadores do próprio risco e do risco do indivíduo médio;

\subsubsection{Relacionado ao julgamento de probabilidades dos cenários}

No que diz respeito às pesquisas sobre risco, Masini (2009) descreve que elas têm, como base, a teoria da personalidade, a qual caracteriza a pessoa por suas qualidades e assim estabelece hipóteses delas com a percepção do risco, como também, da utilização das escalas psicométricas que produzem medidas quantitativas da percepção do risco e benefícios.

$\mathrm{Na}$ visão de Masini (2009, p.16), “[...] o paradigma psicométrico representa uma abordagem em que o risco é particularmente definido e percebido por indivíduos que são influenciados por vários fatores psicológicos, sociais, institucionais e culturais". Nesse sentido, pode-se dizer que a personalidade, uma vez inserida na concepção do risco, também se apresentar no processo de julgamento, da mesma forma que se aceita que essa percepção sofre influência de vários fatores como psicológicos, sociais, institucionais e culturais quando visualizada pelo modelo psicométrico.

Nesse contexto, acredita-se que o grau de independência, fontes externas de informações e subordinação de função possam exercer um efeito no processo de julgamento dos cenários. Sendo assim, com o intuito de verificar uma associação com o viés otimista, bem como um efeito na mitigação da estimativa da probabilidade, foram selecionadas três 
variáveis como proxies dos fatores acima descritos. São elas: forma de Contratação; fonte adicional de informação e existência de fiscalização de tarefas.

Nesse contexto, os estudos isolados investigaram se os indivíduos participantes da pesquisa alteram seus julgamentos de probabilidade quanto à ocorrência de ativos e passivos contingentes, contudo, os resultados podem ser extrapolados para qualquer decisão contábil. Foram elaborados os cenários e introduzidas, através da forma narrativa, modificações relacionadas às variáveis descritas anteriormente.

Com o intuito de representar a realidade vivenciada pelas empresas, como também, dos elaboradores da informação contábil, foi realizada uma análise preliminar das notas explicativas e demonstrações contábeis das empresas que são obrigadas à divulgação de informações sobre os eventos contingentes. Essa análise permitiu construir eventos comuns de acontecerem nas organizações.

Com o objetivo de garantir uma melhor compreensão dos cenários, foi usado um teste de legibilidade. Esse teste fundamenta sua pontuação a partir de um número médio de sílabas por palavra e de palavras por sentença. Nesse estudo, foi aplicada a técnica Flesch, que parte de uma escala de 100 pontos. A facilidade de compreensão do texto é interpretada a partir da pontuação calculada pelo editor de texto Word. Quanto mais alta a pontuação, mais fácil é de entender o documento. Todos os cenários que fazem parte do experimento tiveram uma pontuação em torno de 60 , considerado de nível fácil.

A resposta do julgamento de probabilidade de ocorrência de cada evento segue uma escala, conforme o modelo do quadro 4.

Quadro 4: Probabilidade de Ocorrência

\begin{tabular}{|l|l|l|l|}
\hline Pontuação & Probabilidade de ocorrência & Pontuação & Probabilidade de ocorrência \\
\hline 0 & ( ) $0 \%$ Nenhuma Probabilidade & 6 & ( ) Acima de $50 \%$ até $60 \%$ \\
\hline 1 & ( ) Até $10 \%$ & 7 & ( ) Acima de $60 \%$ até $70 \%$ \\
\hline 3 & ( ) Acima de $10 \%$ até $20 \%$ & 8 & ( ) Acima de $70 \%$ até $80 \%$ \\
\hline 4 & ( ) Acima de $20 \%$ até $30 \%$ & 9 & ( ) Acima de $80 \%$ até $90 \%$ \\
\hline 5 & ( ) Acima de $30 \%$ até $40 \%$ & 10 & ( ) Acima de $90 \%$ até $100 \%$ \\
\cline { 1 - 2 } & ( ) Acima de $40 \%$ até $50 \%$ & &
\end{tabular}

Fonte: Dados da pesquisa, 2015.

As solicitações dos experimentos foram lidas no início de cada encontro. Foi informado aos participantes de que não existiam respostas incorretas. Neste contexto, a ideia 
era promover tranquilidade aos participantes já que os questionamentos aplicados não tinham como objetivo medir o conhecimento.

Com relação ao experimento 1, acredita-se que o profissional contábil, na condição de empregado, contratado externamente ou prestando o serviço a pedido de algum órgão, possa produzir efeitos distintos com relação ao excesso de otimismo e, consequentemente, ao julgamento das estimativas. Para tanto, foram elaborados dois cenários para os quais os respondentes avaliaram a probabilidade de ocorrência deles em uma escala intervalar que vai de 0 a $100 \%$.

O primeiro cenário contextualiza uma situação onde se atribui, à empresa, um potencial de ela gerar graves danos à natureza. Caso o indivíduo considerasse, com base nas informações disponíveis, a alta probabilidade de ocorrência desse evento, origina-se então um passivo contingente. No segundo cenário, a empresa pleiteia a devolução do imposto de renda sobre o lucro líquido. Da mesma forma que o primeiro evento, a partir do julgamento do indivíduo, caso seja alta essa estimativa, tem-se um possível ativo contingente. Para os dois cenários acima descritos, no que se refere às três variáveis em questão, apenas a variável "forma de contratação" sofreu variação na sua narrativa, ao passo que a fonte adicional de informação e a existência de fiscalização de tarefa mantiveram-se inalteradas.

No experimento 2 analisou-se a variável fonte adicional de informação. As normas que tratam dos itens contingentes permitem ao profissional contábil o uso de relatórios complementares da auditoria, da área jurídica e da administração, bem como de outras fontes para a produção do julgamento. Contudo, espera-se que o compartilhamento de informações complementares advindas externamente tende a conter o excesso de otimismo à medida que altera, no profissional, o nível de confiança de suas estimativas. Nesse experimento formulou-se um cenário que contempla discussão judicial associada à garantia contratual de substituição de peças. Quanto maior a avaliação de probabilidade atribuída pelo indivíduo quanto à ocorrência desse evento mais certa é a constituição de um passivo contingente. $\mathrm{O}$ segundo cenário também contempla discussão judicial, no entanto, acerca de tributação dupla do PIS sobre a receita operacional bruta. Da mesma maneira, a partir do julgamento do indivíduo, caso seja alta a probabilidade de desfecho desse evento constitui-se um ativo contingente. Nos dois cenários acima descritos, das três variáveis em questão, apenas a variável "fonte adicional de informação" sofreu variação na sua narrativa enquanto a forma de contratação e a existência de fiscalização de tarefa se mantiveram inalteradas. Esperava-se que fontes externas de informações pudessem influenciar o indivíduo na 
avaliação das probabilidades desses eventos. A avaliação da probabilidade de ocorrência dos eventos segue uma escala intervalar que vai de 0 a $100 \%$.

O experimento 3 contempla o estudo da variável existência de fiscalização da tarefa a qual se refere ao processo de prestação de contas. Acredita-se que o profissional contábil, ao tomar conhecimento que seu julgamento será examinado por instâncias superiores internas ou externas incite nele a responsabilização quanto às estimativas produzidas e, dessa forma, espera-se uma redução do viés otimista. Dos dois cenários elaborados nesse experimento, o primeiro evidencia reclamatória trabalhista associada à periculosidade. Quanto maior a avaliação de probabilidade atribuída pelo indivíduo quanto à ocorrência desse evento mais certa é a constituição de um passivo contingente. O segundo cenário contempla discussão judicial acerca de dupla tributação sobre a receita operacional bruta, no caso, a não incidência do INSS. Da mesma forma, a partir do julgamento do indivíduo, caso seja alta a probabilidade de desfecho desse evento, constitui-se um ativo contingente. Nos dois cenários acima descritos, das três variáveis em questão, apenas a variável "existência de fiscalização de tarefa" sofreu variação na sua narrativa ao passo que a forma de contratação e a fonte adicional de informação mantiveram-se inalteradas. Acredita-se que o elaborador das informações contábeis, uma vez que necessite submeter suas atividades para fins de fiscalização de gerência superior, esse fato cause influência na estimativa das probabilidades desses eventos. A avaliação da probabilidade de ocorrência dos eventos segue uma escala intervalar que vai de 0 a $100 \%$.

Figura 2 - Organograma da metodologia.

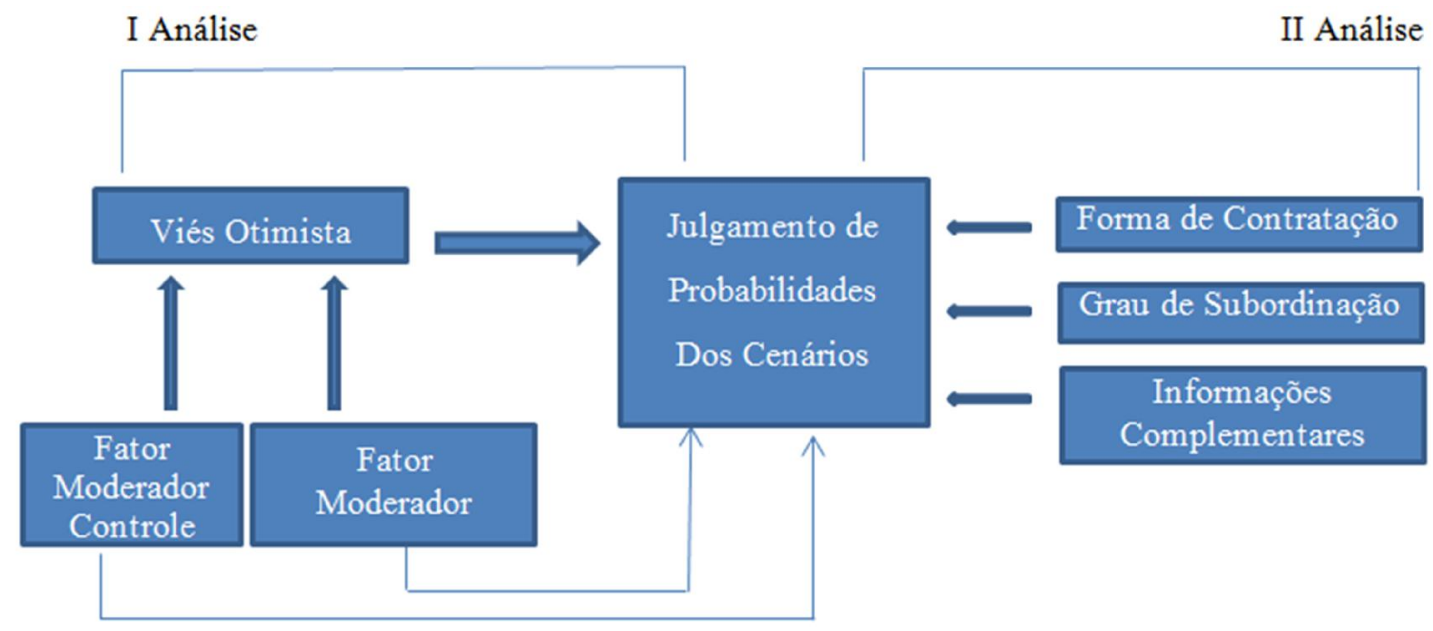

Fonte: Dados da pesquisa, 2015. 


\subsection{AMOSTRA}

\subsubsection{Procedimento para obtenção da amostra}

Com o intuito de garantir a participação dos profissionais nessa pesquisa, a estratégia adotada foi a de oferecer um curso gratuito sobre as Normas Internacionais de Contabilidade, especificamente voltadas para as empresas de pequeno e médio porte. Foram realizadas reuniões com os representantes do $\mathrm{CRC} / \mathrm{RN}$ com a intenção de definir a temática abordada no curso de tal forma que fossem atendidos os interesses do profissional.

Assim, formalizou-se a proposta dele (Ver apêndice E) e o CRC/RN compôs a agenda do Programa de Educação Continuada (PEPC) 2014-2015.

De acordo com o Guia de Orientação (CFC, 2012), o PEPC refere-se a uma atividade programada, formal e reconhecida pelo $\mathrm{CFC}$, a qual objetiva a manutenção, atualização e expansão dos conhecimentos técnicos. Em função disso, exige-se, do Auditor Independente e dos demais contadores que compõem o quadro funcional técnico das empresas de auditoria, o cumprimento de 40 pontos por ano- calendário. A pontuação aprovada para o curso foi de 20 pontos.

Através da colaboração do $\mathrm{CRC} / \mathrm{RN}$ foi feito um convite eletrônico para todos os profissionais ativos. Coube, a este conselho, a administração das inscrições dos interessados e a emissão dos certificados aos participantes que tiveram $100 \%$ de frequência.

\subsubsection{A composição da Amostra Total e Reduzida}

Para o alcance da amostra adequada para atingir os objetivos propostos, o curso foi ofertado três vezes, obtendo-se um total de 128 participantes.

Foram realizadas análises com a amostra total, contudo observou-se que os dados se mostraram confusos. Dessa forma, no processo de identificação de possíveis causas relacionadas optou-se em reorganizar a amostra em tercis para inferir nos resultados de grupos extremos. (Ver Apêndice D).

O uso do EGA (Extreme Groups Approach) visa a detectar efeitos provocados pelos valores extremos (PREACHER, 2015). Esse estudo reorganizou a amostra em dois grupos: um com alta presença do viés otimista e outro sem a presença desse viés. O objetivo de se trabalhar dessa forma é que se visualize o efeito com maior chance: ou seja, aumentou-se o effect size com a intenção de melhor compreender influências de interesses. 
O EGA se apresenta como uma alternativa na solução de diversas dificuldades encontradas para a ponderação dos resultados, especialmente quando a variável em questão é comportamental, sendo muito usado nas pesquisas da área de psicologia e em estudos quaseexperimentais (PREACHER, 2015). De acordo com Preacher (2015), o uso do EGA melhora a relação custo benefício à medida que o pesquisador assume que a distribuição dos extremos também se aplica ao meio omitido.

Sendo assim, em função do uso de grupos extremos para a análise dos dados, a amostra ficou reduzida. Em termos numéricos, isto significa que 87 respondentes, ou $67 \%$ dos resultados, foram objeto de análise.

Para fins de verificar o comportamento da amostra reduzida, foram realizados testes de média para três variáveis relacionadas ao perfil do respondente (idade, experiência e o viés otimista), indicando igualdade de média. Da mesma forma, o teste de proporção também apresentou igualdade. Sendo assim, é possível perceber, conforme a Tabela 1, que não existe diferença expressiva na característica da amostra total e a amostra reduzida. (Ver apêndice B)

Tabela 1 - Comparação entre a amostra total e a amostra reduzida

\begin{tabular}{lccc}
\hline \multicolumn{1}{c|}{ Variáveis } & Amostra Total & Amostra Reduzida \\
\hline $\mathrm{N}$ & 128 & 87 \\
Média da Idade & 38,84 & 39,41 \\
\% Mulheres & $47 \%$ & $52 \%$ \\
Média da Experiência & 12,30 & 11,90 \\
Média do Viés Otimista & $-0,084$ & $-0,100$ \\
\hline
\end{tabular}

Fonte: Dados da Pesquisa, 2015.

\subsection{COLETA DOS DADOS}

O tempo de duração da coleta dos dados compreendeu os meses de agosto, setembro, outubro de 2014 e março e abril de 2015. Assim sendo, foi de trinta dias, com intervalo de sete dias, totalizando quatro encontros. Esses encontros sempre foram realizados aos sábados, no turno matutino, das $9 \mathrm{~h}$ até às $12 \mathrm{~h}$ e de forma sequencial.

A aplicação do questionário foi realizada por encontro. Sendo assim, no primeiro encontro, aplicou-se o questionário referente à métrica do viés otimista e dos fatores moderadores, no segundo encontro foi aplicado o experimento 1 , no terceiro encontro o experimento 2 e, por fim, no quarto encontro o experimento 3. Durante todos os encontros, os instrumentos de coleta foram aplicados sempre no mesmo horário, entre $10 \mathrm{~h}$ e $10 \mathrm{~h} 30 \mathrm{~min}$ da 
manhã, logo após um breve intervalo para lanche. O tempo médio de resposta foi de 5 minutos em cada encontro.

A forma de identificação dos questionários foi feita pelo registro profissional do CRC; neste contexto, a partir do segundo encontro, era verificada a ausência dos indivíduos e, uma vez que esse fato tenha sido constatado, ele era eliminado da amostragem, não participando do resultado. Ou seja, se o indivíduo participou do primeiro e segundo encontro mas faltou o terceiro, mesmo que ele viesse para assistir o curso no quarto encontro, os questionários respondidos por esse indivíduo eram eliminados da amostra, bem como já não recebia o questionário referente ao último encontro. Durante todo o processo, a totalização de perdas de respondentes foi de 15 indivíduos. Uma vez que o número de perdas foi relativamente reduzido, provavelmente não haverá um problema de viés de sobrevivência na pesquisa.

Em função da limitação do espaço físico, o qual compreende um auditório com capacidade para 70 pessoas, no setor 5 da Universidade Federal do Rio Grande Norte, a coleta dos dados se deu em três rodadas e compreendeu o período de 23 de agosto de 2014 à 18 de abril de 2015 .

\subsection{TRATAMENTO ESTATÍSTICO DOS DADOS}

A análise estatística foi realizada contemplando todas as etapas dessa pesquisa. Dessa forma, avaliou-se o nível de confiabilidade do instrumento utilizado para a coleta dos dados, como também a aplicação de técnicas estatísticas para a verificação das relações entre os resultados obtidos conforme os tópicos subsequentes.

Inicialmente, todos os dados coletados foram organizados em uma planilha do Microsot Excel, de tal forma que foi permitida a utilização de tecnologias para a sua análise. Foi feito o uso dos Softwares estatístico Gretl® 1.9.7 (Gnu Regression, Econometrics and Time-series Library) e R®.

Uma vez que os dados são coletados, há a necessidade de se verificar o nível de confiabilidade apresentada por eles. De acordo com Hair et al (2005) a confiabilidade se refere a uma avaliação do grau de consistência entre múltiplas medidas de uma variável, sendo a consistência interna a medida mais utilizada e a sua mensuração se dá através do cálculo do Alpha de Cronbach. Para Hair et al (2005), um valor acima de 0,6 mostra-se adequado para as pesquisas na área de ciências sociais. 
Após a validação do instrumento de pesquisa, foi aplicada a métrica do viés otimista e dos fatores moderadores controle e experiência prévia (conforme tópico 3.3.1). Com o intuito de verificar se esses fatores se relacionam com o viés otimista, usou-se a Análise de Correspondência Múltipla (ACM). De acordo com Hair et al (2005), esse teste se refere a uma técnica de interdependência que promove a redução dimensional da classificação dos objetos em um conjunto de atributos quanto ao mapeamento perceptual de objetos relativos a esses atributos. Permite analisar mutuamente um conjunto de variáveis, pois o método emprega uma tabela de contingência, fazendo elaborações cruzadas tanto de dados não-métricos quanto de relações lineares (HAIR et al, 2005).

Depois de cumprida a etapa acima descrita, optou-se por seguir as análises apenas considerando os grupos extremos. Dessa forma, a amostra foi dividida em tercis e os dados do meio foram desconsiderados.

Com a finalidade de promover a compreensão dos dados coletados e de traçar um perfil dos participantes da pesquisa, foram realizadas as estatísticas descritivas baseada em medidas de posição, tendência central e comparação de frequência. Contudo, com o objetivo de verificar o comportamento da amostra reduzida, calculou-se o teste de médias e o teste de proporção com as variáveis que caracterizam o perfil do respondente.

Com a pretensão de verificar a relação entre os julgamentos de probabilidades avaliados pelos participantes da pesquisa com o viés otimista e os fatores moderadores, aplicou-se o modelo dos mínimos quadrados ordinários (MQO). O objetivo está na constatação de que a presença desse viés no indivíduo possa influenciar suas estimativas de probabilidades.

No que se refere aos experimentos 1, 2 e 3 - apresentados na subseção 3.3.2 - aplicouse o teste de médias e o teste não-paramétrico de Mann-Whitney. O teste de Mann-Whitney serve para testar amostras independentes e avaliar a correlação entre as variáveis. $\mathrm{O}$ cálculo desse teste não leva, em consideração, qualquer distribuição, mas sim as posições ou "ranks". Para a aplicação do teste de Mann Whitney os dados foram organizados de tal forma que se preservou a variável a ser isolada, como também, o comportamento dos grupos. Dessa forma, para cada experimento constitui-se um exame que levou em conta os dois grupos (com a presença do viés otimista e sem a presença desse viés) e as estimativas de probabilidades dos cenários modificados.

Com o intuito de analisar as estimativas de probabilidades levando em conta os grupos com a presença do viés otimista e sem a presença dele, utilizou-se a técnica Odds Ratio, a qual se define a partir da razão entre a chance de um evento ocorrer em um grupo e a chance de ele ocorrer em outro grupo. 


\section{ANÁLISE DOS RESULTADOS}

\subsection{DIMENSIONALIDADE E CONFIABILIDADE DOS DADOS}

Pode-se observar, a partir dos resultados apresentados pela tabela 2, que os valores da correlação com o item total não apresentam valores elevados, como também o quadrado da correlação múltipla.

No que tange ao Alpha de Cronbach, a fidedignidade para a exclusão de cada item, medida a um intervalo de confiança de $95 \%$, não se afasta muito da fidedignidade conjunta do instrumento, sendo de 0,785 para a variável Viés Otimista, situada no intervalo $(0,728$; 0,733); 0,841 para a variável Controle, localizado no intervalo $(0,841 ; 0,828)$ e 0,877 para a variável Experiência, apresentada no intervalo $(0,871$ a 0,865$)$.

Ao se estabelecer uma análise de todos os itens conjuntamente, permite-se concluir que eles apresentam importância equilibrada para a avaliação do conjunto de fatores. Pode-se afirmar que o instrumento aplicado nesse estudo produziu medidas com fidedignidade aceitável e, sendo assim, possui validação interna aceitável. (Ver apêndice C)

Tabela 2 - Medida de fidedignidade do Instrumento

\begin{tabular}{l|c|c|c}
\multicolumn{1}{c}{ Variáveis } & $\begin{array}{c}\text { Cor. Com o item total } \\
\text { Intervalo Q1 a Q20 }\end{array}$ & $\begin{array}{c}\text { Quadrado da Cor. } \\
\text { múltipla } \\
\text { Intervalo Q1 a Q20 }\end{array}$ & $\begin{array}{c}\text { Alpha de Crombach para } \\
\text { o item excluído } \\
\text { Intervalo Q1 a Q20 }\end{array}$ \\
\hline $\begin{array}{l}\text { Viés Otimista } \\
\text { Fator Moderador }\end{array}$ & $(0,389$ a 0,336$)$ & $(0,283$ a 0,332$)$ & $(0,728$ a 0,733) \\
$\begin{array}{l}\text { Controle } \\
\text { Fator Moderador }\end{array}$ & $(0,252$ a 0,520$)$ & $(0,312$ a 0,512$)$ & $(0,841$ a 0,865$)$ \\
Experiência & $(0,360$ a 0,543$)$ & $(0,499$ a 0,631$)$ & $(0,871$ a 0,877$)$ \\
\hline & &
\end{tabular}

\subsection{CARACTERIZAÇÃO DOS PARTICIPANTES E CÁLCULO DO VIÉS OTIMISTA}

As medidas descritivas da amostra reduzida revelam características inerentes ao grupo participante da pesquisa, como também, característica comportamental, tais como a idade, experiência e viés otimista.

No que tange à idade, os valores entre média e mediana não se diferem muito, sendo a média $(39,41)$ representativa. No entanto, isso não ocorre com o tempo de experiência na contabilidade $(11,90)$ nem com o viés otimista $(-0,10)$, para os quais existem fortes diferenças entre essas duas estatísticas (media e mediana). 
Apesar das diferenças acima comentadas, os desvios-padrão mostram, nos valores das idades observadas, uma pequena homogeneidade. No que diz respeito ao tempo de experiência e viés otimista, eles apresentam uma elevada variância. Principalmente, em se tratando do viés otimista, no qual é justificável a forte variabilidade entre os indivíduos em função de representar uma variável comportamental.

No que se refere à assimetria das variáveis, os resultados mostram que a idade e o viés otimista são consideradas moderadas (apresentam valores menor do que 1). (Ver apêndice B)

Tabela 3 - Medidas descritivas da amostra

\begin{tabular}{lccc}
\hline & Idade & Experiência & Viés Otimista \\
Média & 39,41 & 11,90 & $-0,10$ \\
Mediana & 38,00 & 9,00 & $-0,60$ \\
Mínimo & 23,00 & - & $-4,10$ \\
Máximo & 78,00 & 52,00 & 4,10 \\
Desvio & 10,97 & 10,36 & 1,60 \\
Assimetria & 0,89 & 1,47 & $-0,05$ \\
Curtose & 0,77 & 2,34 & $-0,02$ \\
$\mathrm{~N}=87$ & & & \\
\hline
\end{tabular}

Fonte: Dados da pesquisa (2015)

Para obter o índice do viés otimista, os dados da pesquisa foram organizados em planilhas do excel da seguinte forma: As colunas de B até $\mathrm{K}$ representaram as respostas das questões de 1 a 10, as quais se referiam aos participantes da pesquisa. As colunas de $\mathrm{L}$ até a $\mathrm{U}$ representaram as respostas das questões de 11 a 20 , as quais se referiam ao indivíduo médio. As linhas representaram os participantes da pesquisa. A partir desse contexto, foi calculado, o índice do viés para todos os participantes através da fórmula abaixo. A descrição dessa metodologia está exposta no capítulo 3, item 3.3.1.

Índice Viés $=\left[\sum_{j=0}^{5} R I_{j}-\sum_{j=6}^{10} R I_{j}+\sum_{j=0}^{5} R M_{j}-\sum_{j=6}^{10} R M_{j}\right] / 10$

Onde,

RI é a resposta do indivíduo em relação a si;

$\mathbf{R M}$ é a resposta em relação ao indivíduo médio.

Para a classificação dos respondentes em tercis, foi utilizada a opção disponível no excel. Pode-se dizer que os respondentes que obtiveram um EO no intervalo $-0,582<\mathrm{EO}<0,4$ foram desconsiderados da análise. Estes valores correspondem ao primeiro e ao último tercil 
dos dados. Dessa forma, um índice acima de 0,4 não revela a presença do excesso de otimismo ao passo que os que estão abaixo de - 0,582 têm a sua presença confirmada.

Assim sendo, da amostra original $(\mathrm{N}=128)$ foram retirados os indivíduos intermediários e, dessa forma, a nova amostra é composta por 87 indivíduos, sendo que, de 44 participantes foi constatada a presença do viés enquanto para 43 participantes não houve a presença dele. Observa-se, no que diz respeito ao cálculo do viés otimista, que os resultados revelam uma equiparação entre os grupos constituídos.

\subsection{ANÁLISES DAS HIPÓTESES DE PESQUISA}

Para determinar o efeito do otimismo, como também, dos fatores moderadores do grau desse otimismo nas decisões contábeis, foi calculado o modelo de regressão (OLS), sendo as respostas obtidas para as situações que contemplam probabilidades de ocorrência de passivos e ativo contingentes, conforme as hipóteses abaixo descritas. Com relação às regressões realizadas, elas foram submetidas à verificação de violação de premissas. Assim, as regressões estão adequadas quanto à normalidade, heteroscedasticidade, colinearidade e autocorrelação dos dados.

Com o intuito de verificar a estabilidade dos resultados das regressões acima calculadas (tabelas 4,5,6 e 7) foram realizadas transformações nas variáveis dependentes. Dessa forma, ao se modificar o ativo e o passivo em logaritmo e rodar novamente as regressões, observou-se que os mesmos coeficientes se mantiveram significantes, bem como, o seu sinal. (Ver apêndice C).

\subsubsection{Hipótese 1}

No que diz respeito aos ativos contingentes, acredita-se que a presença do viés otimista no indivíduo faz com que ele tenda a aumentar a probabilidade da ocorrência desses eventos.

Com relação aos fatores moderadores experiência e controle com os eventos em questão, espera-se que eles conduzam o indivíduo a fazer julgamentos mais conservadores. Dessa maneira, pode-se atestar a influência de cada uma das variáveis explicativas em questão (viés otimista, fator moderador controle e experiência) sobre a variável dependente (julgamentos de ocorrência de ativos contingentes). 
Com o intuito de adequar os dados ao modelo OLS, antes de efetuar a regressão, verificou-se uma forte correlação entre os cenários ativo e passivo. Dessa forma, foi possível somar as estimativas de probabilidade de todos os cenários ativos, como também dos passivos e assim constituir a variável dependente.

$$
\begin{gathered}
\text { Ativo }_{i}=\beta_{1} \text { DummyEO }_{i}+\beta_{2} \text { FMCon }_{i}+\beta_{3} \text { FMExp }_{i} \\
+\varepsilon_{i}
\end{gathered}
$$

Onde:

Ativo $_{i}$ é representado pela soma dos julgamentos dos três cenários ativos;

$\beta_{1}$ DummyEO $_{i}$ representa o perfil do viés otimista sendo considerado 1 com a presença do viés e 0 sem a presença viés;

$\beta_{2} \mathrm{FMCon}_{i}$ representa o fator moderador controle sendo considerado $1 \mathrm{com}$ a presença do fator e 0 sem a presença fator;

$\beta_{3} F M E x p_{i}$ representa o fator moderador experiência sendo considerado 1 com a presença desse fator e 0 sem a presença do fator;

$\varepsilon_{i}$ termo de erro

Tabela 4 - Regressão Linear Múltipla variável dependente: Ativo

\begin{tabular}{lcccc}
\hline \multicolumn{1}{c}{ Variáveis Explicativas } & Coeficiente & Erro Padrão & Razão t & p-valor \\
\hline Viés Otimista $\beta 1$ & 20,1771 & 2,48245 & 8,1279 & $<0,00001 * * *$ \\
Fator Moderador Controle $\beta 2$ & 2,11758 & 1,68813 & 1,2544 & 0,21318 \\
Fator Moderador Experiência $\beta 3$ & 1,43735 & 1,31436 & 1,0936 & 0,27727 \\
\cline { 2 - 5 } $\mathrm{F}(3,84) ;$ P-valor(F) & \multicolumn{4}{c}{22,$61786 ; 7,93 \mathrm{e}-11$} \\
$\mathrm{R}^{2}$ & \multicolumn{4}{c}{0,446836} \\
\hline
\end{tabular}

Fonte: Dados da Pesquisa (2015)

De acordo com a tabela 04 pode-se observar que os fatores moderadores controle e experiência não se revelaram significantes na equação e, dessa forma, optou-se pela omissão dessas variáveis, sendo usado o método stepwise.

Ao se analisar os coeficientes gerados pelo novo modelo (tabela 5), observa-se que indivíduos excessivamente otimistas produzem julgamentos de probabilidades maiores para os eventos representativos de ativos contingentes e os indivíduos não excessivamente otimistas tenderam a julgar essas probabilidades para baixo.

No modelo de regressão, o viés otimista se apresenta como variável significante ao nível de $1 \%$. O poder explicativo do modelo é de aproximadamente $44 \%$ e a estatística $\mathrm{F}$ $(33,25220)$ e, dessa forma, é possível considerar que o modelo de regressão é adequado. 
Tabela 5 - Regressão Linear Múltipla do Ativo com stepwise

\begin{tabular}{lcccc}
\multicolumn{1}{c}{ Variáveis Explicativas } & Coeficiente & Erro Padrão & Razão t & p-valor \\
\hline Viés Otimista $\beta 1$ & 19,4435 & 2,39285 & 8,1257 & $<0,00001 * * *$ \\
Fator Moderador Controle $\beta 2$ & 2,80375 & 1,56899 & 1,7870 & $0,07751^{*}$ \\
\cline { 2 - 5 } $\mathrm{F}(2,85) ;$ P-valor(F) & \multicolumn{4}{c}{$0,43,25220 ; 2,15 \mathrm{e}-11$} \\
\cline { 2 - 4 } $\mathrm{R}^{2}$ & \multicolumn{4}{c}{0,4380} \\
\hline
\end{tabular}

Fonte: Dados da pesquisa (2015)

Os resultados da relação acima apresentada contrariam a teoria do conservadorismo, a qual apregoa que as boas notícias devem ser postergadas. No entanto, para esse estudo uma vez que se atribui maiores probabilidades para o conjunto de eventos ativos, isso faz com que essa categoria de ativos tenha seus resultados considerados como certos e assim antecipados nas demonstrações financeiras, gerando uma evidenciação com melhores resultados.

Ao se estabelecer uma análise com a teoria da psicologia, a similaridade foi observada no que se refere aos sinais. Ou seja, indivíduos com a presença do viés tendem a estabelecer probabilidades maiores para os ativos contingentes.

\subsubsection{Hipótese 2}

Espera-se que, uma vez identificada a presença do viés otimista no indivíduo, ele tenda a subestimar a ocorrência de eventos passivos contingentes. No entanto, caso esse indivíduo se avalie bastante experiente com os eventos em questão, espera-se que essa experiência o conduza a julgamentos mais conservadores. Já com relação ao fator moderador controle era esperado que um maior controle provocasse um maior efeito no viés e, consequentemente, no julgamento. Dessa maneira, pode-se atestar a influência de cada uma das variáveis explicativas em questão (viés otimista, fator moderador controle e experiência) sobre a variável dependente (julgamentos de ocorrência de passivos contingentes).

$$
\begin{gathered}
\text { Passivo }_{i}=\beta_{1} \text { DummyEO }_{i}+\beta_{2} \text { FMCon }_{i}+\beta_{3} \text { FMExp }_{i} \\
+\varepsilon_{i}
\end{gathered}
$$

Onde:

Passivo $_{i}$ é representado pela soma dos julgamentos dos três cenários passivos;

$\beta_{1}$ DummyEO$_{i}$ representa o perfil do viés otimista sendo considerado 1 com a presença do viés e 0 sem a presença viés;

$\beta_{2} F_{M C o n}$ representa o fator moderador controle sendo considerado $1 \mathrm{com}$ a presença do fator e 0 sem a presença fator; 
$\beta_{3} F M E x p_{i}$ representa o fator moderador experiência sendo considerado 1 com a presença desse fator e 0 sem a presença do fator;

$\varepsilon_{i}$ termo de erro

Tabela 6 - Regressão Linear Múltipla variável dependente: Passivo

\begin{tabular}{lcccc}
\hline \multicolumn{1}{c}{ Variáveis Explicativas } & Coeficiente & Erro Padrão & Razão t & p-valor \\
\hline Viés Otimista $\beta 1$ & 20,6195 & 2,34628 & 8,7882 & $0,00001 * * *$ \\
Fator Moderador Controle $\beta 2$ & 3,2531 & 1,59553 & 2,0389 & $0,04461 * *$ \\
Fator Moderador Experiência $\beta 3$ & 0,919915 & 1,24226 & 0,7405 & 0,4610 \\
F (3, 84); P-valor (F) & \multicolumn{4}{c}{27,$26331 ; 2,08 \mathrm{e}-12$} \\
$\mathrm{R}^{2}$ & \multicolumn{4}{c}{0,493335}
\end{tabular}

Fonte: Dados da pesquisa (2015)

Conforme observado na Tabela 6, no modelo de regressão acima apresentado, o fator moderador experiência não se mostrou significante na equação. Sendo assim, foi refeita a regressão do tipo stepwise, excluindo-se as variáveis não significativas.

Analisando os coeficientes, pode-se perceber que os indivíduos excessivamente otimistas produzem julgamentos de probabilidades maiores para os eventos representativos de passivos contingentes e os indivíduos não excessivamente otimistas tenderam a julgar essas probabilidades para baixo. Os resultados revelam que o fator moderador controle causa influência significativa no julgamento dessas probabilidades. Os indivíduos com mais controle tendem a fazer um julgamento maior para os eventos passivos. Ou seja, o aumento de uma unidade no escore controle aumenta o julgamento de probabilidade dos eventos passivos em 3,25 unidades. No modelo de regressão o viés otimista apresenta-se como variável significante ao nível de $1 \%$, enquanto o fator moderador controle a significância estatística é percebida ao nível de 5\% no modelo de regressão.

A equação de regressão da tabela 7 atingiu um poder explicativo para a variabilidade da variável dependente em $49 \%$ que é o coeficiente de determinação ajustado e pela estatística F $(40,83777)$ pode-se observar que o modelo de regressão é adequado.

Tabela 7 - Regressão Linear Múltipla do Passivo com stepwise

\begin{tabular}{lcccc}
\hline \multicolumn{1}{c}{ Variáveis Explicativas } & Coeficiente & Erro Padrão & Razão t & p-valor \\
\hline Viés Otimista $\beta 1$ & 20,15 & 2,25299 & 8,9437 & $0,00001 * * *$ \\
Fator Moderador Controle $\beta 2$ & 3,69225 & 1,47728 & 2,4994 & $0,01436 * *$ \\
\cline { 2 - 5 } F(2, 85); P-valor(F) & \multicolumn{4}{c}{40,$83777 ; 3,72 \mathrm{e}-13$} \\
$\mathrm{R}^{2}$ & \multicolumn{4}{c}{0,490027}
\end{tabular}

Fonte: Dados da pesquisa (2015) 
A influência positiva, acima evidenciada, entre os indivíduos que possuem o otimismo exacerbado e seus julgamentos de probabilidades de ocorrência de eventos passivos, ao se analisar sob a ótica da teoria do conservadorismo observa-se que ela se confirma ante o fato de refletir a antecipação das más notícias.

Os julgamentos de probabilidades maiores para os cenários que representam a saída de recursos faz com que eles sejam reconhecidos como passivos contingentes nas demonstrações financeiras ou nas notas explicativas. Sendo alta a probabilidade de ocorrência, tem-se, dessa forma, um resultado diminuído em função da antecipação dessas despesas. Por outro lado, Prado (2014) comenta que as empresas, em alguns casos, ao assumirem os riscos potenciais como passivos contingentes nas notas explicativas, consideraram suas contingências como possíveis, assumindo uma postura otimista em relação ao real nível dos riscos potenciais dos quais a empresa está envolvida, diminuindo, dessa forma, o nível de endividamento e não os evidenciando nas demonstrações financeiras.

\subsubsection{Hipótese 3}

Com o objetivo de estudar a relação entre o viés otimista e os fatores moderadores Controle e Experiência prévia, aplicou-se a técnica da análise de correspondência múltipla. Foi utilizado o método de normalização simétrico, sendo atribuída a cada variável a mesma ponderação. Os achados da pesquisa revelam que, nas duas dimensões, atingiu-se 100,0\% da inércia total. O diagrama de associações entre os níveis das categorias das três características comportamentais classificadas por seus vieses Baixo, Médio e Alto de acordo com os quartis delas é mostrado na tabela abaixo. (Ver apêndice C).

Era esperado uma relação direta entre o fator moderador controle e o viés otimista e os resultados confirmam essa relação. Contudo, para o fator moderador experiência prévia e esse viés a associação não se confirma. $\mathrm{O}$ resultado mostra que, se um viés é baixo em uma característica, também o será nas demais. Da mesma forma, se for alta em um atributo também será nas demais.

Tabela 8 - Associação entre viés otimista e fatores moderadores

\begin{tabular}{lccccc}
\hline Dimensão & Valor Singular & Autovalor & Inércia & \% Inércia. & $\begin{array}{c}\text { \% Inércia } \\
\text { acumulada }\end{array}$ \\
1 & & & & & 69,7 \\
2 & 0,546 & 1,572 & 0,524 & 30,3 & 69,7 \\
Total & 0,300 & 1,250 & 0,4171 & 100,0 \\
\hline
\end{tabular}

Fonte: Dados da pesquisa (2015) 


\subsection{RESULTADOS DOS EXPERIMENTOS}

Com o intuito de investigar o efeito das variáveis (forma de contratação, fonte adicional de informação e existência na fiscalização de tarefas) no julgamento das probabilidades em questão, estabeleceu-se inicialmente o teste de médias. No entanto, por conta do tamanho reduzido da amostra, não foi possível aplicar o referido teste. Nesse contexto, optou-se pela aplicação do teste não paramétrico de Mann Whitney, mostrando-se mais adequado para a análise, sendo recomendado para uma amostra não pareada.

Estabelecendo-se uma análise conjunta a qual considera os três experimentos, os resultados do teste de Mann Whitney não se revelaram significativos. Examinando-se por variável isolada para o grupo no qual não há a presença do viés otimista, os achados revelam um p-valor de 0,0362 para a forma de contratação externa. Quanto à variável fonte adicional de informação advinda da análise jurídica, depreendeu-se que apresenta uma suave significância estatística (p-valor de 0,0869). Ou seja, esperava-se que as variáveis descritas anteriormente pudessem influenciar o julgamento, no sentido de alterar significativamente as taxas de probabilidades de ocorrência dos eventos, contudo, os resultados do teste não confirmam essa possibilidade.

Uma possível causa para a não verificação da influência se deve ao tamanho da amostra. Contudo, dada a dificuldade do experimento, não foi possível obter um aumento dela; entretanto, se, ao aplicar um quase-experimento de forma presencial, tem-se essa dificuldade, por outro lado, realizar uma coleta de dados via internet causa um baixo controle do ambiente off line. Dessa forma, apresenta-se um trade-off entre correr o risco de não obter resultados significantes e coletar dados que talvez não representam um nível de fidedignidade adequado à análise.

Outro motivo da falta da influência dessas variáveis no julgamento das estimativas de probabilidades de ocorrência dos eventos contingentes talvez esteja relacionada ao desenho do experimento no que se refere às variáveis em questão e, dessa forma, o experimento não tenha conseguido capturar as informações que se buscava obter, ou simplesmente não exista o efeito.

\subsection{EFEITOS DO VIÉS OTIMISTA NOS JULGAMENTOS CONTÁBEIS}

Com o intuito de verificar uma associação entre os grupos (com a presença do otimismo exagerado e sem a presença desse viés), a partir do julgamentos de probabilidades 
estimados pelos participantes, foi usada a técnica Odds Ratio, a qual se fundamenta na razão de chances. Em outras palavras, através dessa análise, é possível comparar as avaliações realizadas pelos indivíduos e, dessa forma, inferir sobre seus efeitos na evidenciação contábil. Para a aplicação do teste, o exame parte da análise dos julgamentos dos cenários que apresentam probabilidades iguais ou inferiores a 50\% para o grupo excessivamente otimista. A decisão desse percentual para fins de exemplificação da análise se deve em função de que, acima desse parâmetro, o impacto na evidenciação se revela com mais significância.

Por outro lado, ao se verificar as práticas adotadas pelas empresas do mercado, observa-se que as respostas localizadas no intervalo de 0 a $25 \%$ são consideradas como sendo possibilidades remotas de acontecer; para aquelas que indicam uma estimativa acima de $25 \%$ até $50 \%$, existe a possibilidade de ocorrer o evento; e, por fim, as respostas que representam percentuais acima de $50 \%$ até $100 \%$, são prováveis de acontecer (FIPECAFI, ERNST; YOUNG, 2013).

Os resultados mostram que os indivíduos com a presença do viés otimista efetuam julgamento de probabilidades com expectativas abaixo ou igual a $50 \%$ para os cenários $1,2 \mathrm{e}$ 6. Há 1,87 vezes mais chance de um indivíduo com presença desse viés, nas suas decisões, atribuir probabilidade menor ou igual a 50\% para o cenário um (passivo); 1,40 vezes para o cenário seis (ativo) e, 2,01 para o cenário dois (ativo), isso quando comparados com aqueles que não apresentam o viés.

Contudo, para os cenários 3, 4 e 5, as associações são contrárias. Os achados da pesquisa revelam que os indivíduos com a presença do viés apresentaram um julgamento de probabilidade com expectativas acima de 50\%. Há 1,53 vezes mais chances de um indivíduo com a presença desse viés, nas suas decisões, atribuir probabilidade maior que $50 \%$ para o cenário três (Passivo) e 1,04 vezes para os cenários quatro (ativo) e cinco (passivo).

No entanto, ao se analisar a significância estatística pelo intervalo de confiança, os achados acima não se mostram significativos, pois o valor de 1 está contido em seus intervalos não sendo, portanto, um efeito real na população. Contudo, Rumel (1986) destaca que o tamanho da amostra aleatória poderá não afetar o odds ratio, mas afetará seu intervalo de confiança e, dessa forma, pode afetar a sua significância estatística.

A tabela 9 foi construída levando-se em consideração o número total de julgamentos realizados pelos respondentes dessa pesquisa. Nesse contexto, tem-se, no total, 522 estimativas de probabilidades (6 cenários x 87 respondentes). 
Tabela 9 - Medida de Associação entre o perfil EO e os cenários

\begin{tabular}{c|c|c|c|c|c|c|c|c}
\hline \multirow{2}{*}{ EO } & \multirow{2}{*}{ Prob } & \multicolumn{8}{c|}{ Cenários } & \multicolumn{2}{c}{ Total } \\
\cline { 3 - 8 } 1 & $\leq 50 \%$ & 22 & 2 & 3 & 4 & 5 & 6 & 128 \\
& $>50 \%$ & 22 & 18 & 22 & 25 & 26 & 23 & 136 \\
2 & $\leq 50 \%$ & 15 & 18 & 26 & 19 & 18 & 17 & 113 \\
& $>50 \%$ & 28 & 25 & 17 & 24 & 25 & 26 & 145 \\
\multicolumn{2}{c}{ Odds Ratio } & 1,87 & 2,01 & 0,654 & 0,96 & 0,96 & 1,40 & \\
\hline
\end{tabular}

Fonte: Dados da pesquisa (2015)

Nota: $\mathrm{EO}=$ excesso de otimismo (Grupo 1 com viés; Grupo 2 sem viés)

Com o objetivo de verificar o impacto do julgamento das estimativas na evidenciação contábil, efetuou-se uma análise a partir dos cenários descritos nos experimentos. Sabe-se que a intensidade do julgamento das probabilidades dos eventos contingentes indicados pelos indivíduos produz diferentes formas de evidenciação desses possíveis riscos. Prado (2014), ao destacar a importância da divulgação das contingências para o mercado, argumenta que, dessa forma, as empresas demonstram como lidam com seus riscos potenciais relacionados aos seus negócios, sendo, nesse contexto, informações relevantes para os modelos de avaliação das empresas.

Tomando-se os julgamentos dos indivíduos excessivamente otimistas para os eventos que representam desembolsos de caixa, verifica-se que, ao estimarem probabilidades mais altas (maior que 50\%) para o passivo ora representado pelos cenários 3 e 5 (garantias contratuais e reclamatórias trabalhistas), esses eventos irão sofrer o reconhecimento na contabilidade, gerando um aumento no nível das dívidas e o registro de uma despesa com a consequente diminuição do resultado.

Sob a ótica do usuário da informação, uma redução do resultado pode apresentar vários impactos. Imaginando-se um gestor que tenha seu plano de remuneração com base no lucro essa situação poderia acarretar sua desmotivação ou talvez um gerenciamento de resultados, já para um investidor ele estaria revendo seus planos de investimento, como também, analisando a importância da transparência das ações nas quais a empresa tivesse envolvimento.

Para Fields, Lys e Vincent (2001) a capacidade de detectar o gerenciamento de resultados é uma questão importante porque a maior parte das hipóteses sobre as implicações das escolhas contábeis contam com a premissa de que as partes interessadas são, possivelmente, incapazes para detectar o efeito do método contábil escolhido, bem como dos procedimentos e estimativas contábeis. 
No que se refere ao planejamento dos desembolsos de caixa, Portella et al (2015) enfatizam a importância da evidenciação dos eventos contingentes decorrentes de ações. Os autores comentam que, em decorrência da opinião de juristas especializados, como também, da experiência de sentenças anteriores, quando as empresas mencionam esses passivos nas notas explicativas, criam um alerta para os gestores e investidores de que a empresa possa vir futuramente a constituir novas provisões em virtude do provável desembolso.

No caso dos ativos contingentes, a interpretação é de verificar se a entrada de benefícios econômicos é praticamente certa, provável (mas não praticamente certa) e não provável. No contexto dessa pesquisa, o evento 4 foi avaliado com expectativas acima de $50 \%$ estando, dessa forma, alinhado com o que se orienta na contabilidade. Contudo, os cenários 2 e 6 (que tratam de restituição de tributos) foram avaliados com expectativas inferiores a 50\%, essa possibilidade de entrada de recursos não sofreria nenhuma forma de registro pelo fato de terem sido indicadas expectativas inferiores a 50\%. Tomando-se, como exemplo, o gestor, ao não se fazer o registro dos ingressos de caixa, os planejamentos e orçamentos sofrem um impacto direto, sob a ótica do fisco, de modo que isso pode ser visto como uma forma de evasão tributária, e, sob o olhar dos investidores, os resultados mostramse menos atraentes além de interferir na transparência das ações contingentes relacionadas à empresa.

Antunes et al (2012) comentam que os usuários das demonstrações contábeis, ao fazerem suas análises, consideram a necessidade de ajustes com o intuito de adequar ao perfil e a aversão aos riscos. A título de exemplo, pode-se dizer que um investidor arrojado, em vez de lançar, em notas, os ativos contingentes, já faria, de imediato, um reconhecimento nas demonstrações contábeis, ao passo que um investidor conservador, no que se refere aos passivos contingentes, poderia ajustar as demonstrações contábeis não fazendo o seu reconhecimento e, assim, aumentaria a segurança quanto aos riscos relacionados a um investimento.

Em um estudo realizado por Barros e Silveira (2008) que teve como objetivo analisar se o excesso de confiança e otimismo influenciavam significativamente as decisões de financiamento das empresas, os autores revelam que os gestores classificados como excessivamente confiantes e otimistas são, em média, mais expostos ao risco estimado do negócio quando comparados aos demais. Sendo assim, uma vez que se mantém inalteradas as demais circunstâncias, a tendência é de que esses gestores apresentem comportamentos mais cautelosos ou conservadores, e, dessa forma, escolher uma estrutura de financiamentos menos alavancada. 
Viviani e Fernandes (2014) realizaram um estudo que avaliou a qualidade da evidenciação dos passivos contingentes relacionados ao risco legal das empresas do setor petrolífero. Os pesquisadores revelaram, através dos achados da pesquisa, a falta de um consenso entre as práticas de evidenciação desses passivos e concluíram que esse fato aconteceu por conta da existência de diferenças nos julgamentos dos profissionais que preparam as demonstrações contábeis e as notas explicativas.

Os estudos expostos anteriormente revelam a preocupação com a qualidade da evidenciação da informação contábil, especificamente, dos eventos contigentes e a relação com os aspectos do julgamento. 


\section{CONSIDERAÇÕES FINAIS}

Essa tese teve, como objetivo, analisar os efeitos do viés emocional do otimismo exagerado no julgamento do profissional contábil, no que se refere à avaliação das probabilidades de ocorrência de ativos e passivos contingentes. Para tanto, estabeleceu-se uma análise a partir de dados extremos, nesse sentido, foram analisados os dados que correspondem ao primeiro e ultimo tercil. Após a aplicação da métrica do viés otimista, foi constatado que, do total da amostra examinada, tem-se 44 indivíduos para os quais foi constatada a presença desse viés, ao passo que, para 43 participantes, não houve a presença deste fator.

Com base na análise das estimativas indicadas pelos participantes excessivamente otimistas, foi possível verificar a existência da influência do viés. Ao se fazer a regressão entre as avaliações de probabilidades de ativos e passivos contingentes com as variáveis independentes ora representadas pelo perfil do viés otimista e fatores moderadores de eventos como o controle e experiência prévia, foi possível verificar essa relação quanto ao viés. Estabelecendo-se uma análise em um contexto geral dessa pesquisa, pode-se dizer que há a influência significativa do viés otimista nas avaliações das estimativas de probabilidades dos eventos. Entretanto, observa-se que os impactos não acontecem da forma prevista nas teorias que embasam o viés otimista.

Para os fatores moderadores Controle e Experiência prévia foi possível constatar as relações entre esses e o viés otimista. Quanto às relações, os resultados revelam 100\%, isso mostra que, se um viés é baixo em uma característica, também o será nas demais. Da mesma forma, se for alta em um atributo, também o será nas demais.

Para a análise dos julgamentos de probabilidades os resultados mostram que os indivíduos com a presença do viés otimista efetuam julgamento de probabilidades com expectativas abaixo ou igual a 50\% para os cenários 1 (passivo), 2 e 6 (ativos), isso quando comparados com aqueles que não apresentam o viés. Contudo, para os cenários 3 (passivo), 4 (ativo) e 5 (passivo) os achados da pesquisa revelam que os indivíduos com a presença do viés apresentaram um julgamento de probabilidade com expectativas acima de 50\%.

Era esperado, para todos cenários ativos, os quais representam eventos positivos, estimativas com probabilidades superiores a $50 \%$, no entanto, não se confirmaram para os eventos 2 e 6. Já para os cenários passivos, os quais representam eventos negativos, eram aguardados julgamentos de probabilidades inferiores a $50 \%$, contudo, apenas para o cenário 1 , 
esse fato se confirmou. Dessa forma, percebe-se a influência do viés na avaliação das estimativas, de modo que daí decorrem os impactos na evidenciação desses eventos.

A atividade de julgar - que por si só contém um grau elevado de subjetividade -, aliada à presença de um viés otimista, faz com que haja diferentes modos de os contabilistas estimarem as probabilidades e, nesse contexto, o impacto é sentido fortemente na comprovação dessa classe de eventos, pois julgamentos baixos conduzem à falta de registros e menções em notas, ao passo que os mais elevados se concretizam no reconhecimento e evidenciação nas demonstrações contábeis.

No que diz respeito às variáveis examinadas (forma de contratação, fonte adicional de informações e existência de fiscalização de tarefas) não foi possível constatar alterações nas avaliações das estimativas de probabilidades dos eventos contingentes em decorrência das modificações de narrativas relacionadas às variáveis supra-descritas. Talvez a narrativa não tenha conseguido efetuar a captura dos questionamentos como era o esperado.

Contudo, essa tese apresenta contribuições tanto aos usuários internos como externos. Com o intuito de exemplificar tem-se o estabelecimento de previsões na projeção de cenários e orçamentos sejam públicos ou privados, bem como, na estimativa do tempo de conclusão de tarefas da auditoria para a determinação de honorários. As influências do excesso de otimismo podem ser observadas e uma vez identificada a presença desse viés, podem-se criar mecanismos que minimizem os efeitos dessas decisões.

A maior parte dos trabalhos publicados que versam sobre vieses comportamentais examinam a influência dos mesmos no tomador de decisão a partir de informações publicadas. Esse estudo teve como objetivo investigar, a partir do elaborador da informação contábil, o risco de enviesamento, nesse caso do otimismo exagerado. Dessa forma, à medida que se analisa a presença do viés otimista no profissional contábil, torna-se importante, para o processo de decisão dos usuários externos, saber o modo como a percepção de risco é determinada por esse indivíduo e levar isso em conta nas suas decisões.

No que se refere às limitações da pesquisa, tem-se a constituição da amostra como uma forte limitação devido às dificuldades inerentes à disponibilidade dos respondentes em participar de pesquisas dessa modalidade. Outro obstáculo enfrentado diz respeito ao propósito dos estudos que versam sobre o viés otimista. A maior parte dos trabalhos dispostos na literatura tratam da aplicação desse viés nos estudos de doença e dos vícios causadores de doenças com o propósito de intervenção. Desse modo, a análise dessa tese é dificultada por ser de área adversa, posto que inexiste poder comparativo quanto aos resultados dessa pesquisa. 
Sugerem-se estudos futuros que visem a verificar uma relação entre o viés otimista e o julgamento de probabilidades com o acréscimo de novas informações, como também, da influência dos fatores moderadores nesses julgamentos dos ativos e passivos contingentes. Outra proposta diz respeito ao aprofundamento de variáveis que possam influenciar o grau do viés otimista e/ou os julgamentos de probabilidades dos eventos ora examinados.

E, finalmente, cabe um maior aprofundamento desse estudo no intuito de verificar a relação entre o viés otimista e o conservadorismo, pois durante muito tempo o elaborador da informação contábil exerceu suas atividades com base em regras e, sendo assim, parece pertinente investigar acerca da elaboração de informações, atualmente, pautadas em julgamentos. 


\section{REFERÊNCIAS}

ANDRADE, Rogério P. A construção do conceito de incerteza: uma comparação das contribuições de Knight, Keynes, Shackle e Davidson. Nova Economia. Belo Horizonte/MG Vol.21, n. 2, p. 171-195, 2011.

ANTUNES, M. et al. A adoção no Brasil das normas internacionais de contabilidade IFRS: o processo e seus impactos na qualidade da informação contábil. Revista de Economia \& Relações Internacionais. V. 10, N. 20, p. 5-19, 2012.

ARMOR, D. A; TAYLOR, S. E. Situated optimism: Specific outcome expectancies and selfregulation. Advances in Experimental Social Psychology, [S.1.; s.n], v. 30, p. 309-379, 1998.

BANDEIRA, M.. Delineamentos quase-experimentais. (2012). Disponível em: http://www.ufsj.edu.br/portal2-repositorio/File/lapsam/Textos/Texto\%206-DELINEA MENTO\%20QUASE\%20EXPERIMENTAL_A-B_.pdf. Acesso em: 10 de maio de 2012.

BARROS, Lucas Ayres Barreira de Campos; SILVEIRA, Alexandre Di Miceli da. Excesso de confiança, otimismo gerencial e os determinantes da estrutura de capital. Revista Brasileira de Finanças. V. 6, N. 3, p. 293-334, 2008. Disponível em: < Http://bibliotecadigital.fgv.br/ojs/index.php/rbfin/article/viewFile/1343/683.. >. Acesso em: 30 abr. 2016.

BASU, S. The conservatism principle and the asymmetric timeliness of earnings. Journal of Accounting and Economics, [S.1.; s.n], v. 24, n. 1, p. 3-37, 1997.

BENNETT, B.; BRADBURY, M.; PRANGNELL, H. Rules, Principles and Judgments in Accounting Standards. ABACUS, [S.1.; s.n], v. 42, n. 2, p. 189-204, 2006.

BERESFORD, Bryony; SLOPER, Tricia. Understanding the Dynamics of Decision-Making and Choice: A Scoping Study of Key Psychological Theories to InformThe Design and Analysis of the Panel Study. Social Policy Research Unit, University of York, 2008.

BONNER, S. E. Judgement and decision making in accounting. New Jersey: Person Prentice Hall, 2008.

CAMPBELL, J. et al. Unrealistic optimism in internet events. Computers in Human Behavior. V. 23, N. 3, [S.1.; s.n], p. 1273-1284, 2007.

COELHO, M. Unrealistic Optimism: what it is and how to deal with it. Department of Management Research: The Journal of the Iberoamerican Academy of Management. [S.1.; s.n], V. 10, N. 3, p. 226-238, 2012.

COMITÊ DE PRONUNCIAMENTOS CONTÁBEIS - CPC. Pronunciamento Conceitual Básico (R1): Estrutura Conceitual para a elaboração e Divulgação de Relatório Contábil- Financeiro. 2011. Disponível em: <http://static.cpc.mediagroup.com. br/Documentos/147_CPC00_R1.pdf >. Acesso em: 30 Jul. 2014.

COMITÊ DE PRONUNCIAMENTOS CONTÁBEIS - CPC.CPC. Pronunciamento Técnico CPC 25: Provisões, Passivos Contingentes e Ativos Contingentes. 2009. Disponível em: < 
http://static.cpc.mediagroup.com.br/Documentos/304_CPC_25.pdf $>$. Acesso em: $30 \mathrm{Jul}$. 2014.

DARABI, Roya,FAGHANI, Mehdi .The Disclosure Effects of Contingent Liabilities and Ambiguities On Making Decision by Users of Financial Statements www.ijbcnet.com International Journal of Business and Commerce. [S.l.; s.n], Vol. 1, No. 5: Jan 2012 [1321] (ISSN: 2225-2436).

DICKHAUT, J. The Brain as the Original Accounting Institution. The Accounting Review. [S.1.; s.n], V. 84, N. 6, p. 1703-1712, 2009.

DILLARD, A. J.; MIDBOE, A. M.; KLEIN, W. M. P. The dark side of optimism: Unrealistic optimism about problems with alcohol predicts subsequent negative event experiences.

Personality and Social Psychology Bulletin, [S.l.; s.n], V. 35, N. 11, p. 1540-1550, 2009.

DYE, Ronald. An evaluation of "essays on disclosure" and the Disclosure literature in accounting. Journal of Accounting and Economics, Burlington, [S.1.; s.n], Vol. 32 ,181$235,2001$.

FIELDS, Thomas D., LYS, Thomas Z., VINCENT, Linda. Empirical research on accounting choice. Journal of Accounting and Economics, vol. 31, issue 1-3, p. 255-307, 2001.

FIFE-SCHAW, C. BARNETT, J. Measuring Optimistic Bias. In: BREAKWELL, G. M. Doing Social Psychology Research. John Wiley \& Sons, p. 54-74, 2008.

FINUCANE, Melissa L., PETERS, Ellen, SLOVIC, Paul. Judgment and Decision Making: The Dance of Affect and Reason In press in Schneider, S. L., \& Shanteau, J. (Eds.). Emerging perspectives on decision research. Cambridge University Press. Draft January $10,2002$.

FIPECAFI; ERNST \& YOUNG. Análises sobre o IFRS no Brasil. São Paulo, 2013.

GREEN, L; MYERSON, J. A discounting framework for choice with delayed and probabilistic rewards. Psychological Bulletin 2004;130:769-792.

HAIR , J. F., et al. Análise multivariada de dados. 5 ed. Porto Alegre: Bookman, 2005.

HANNA, W.; BARBERA, J. Desenho Lippy the Lion \& Hardy Har Har. In: The HannaBarbera New Cartoon Series. [S.1.; s.n], USA: BIG Carton Data Base, Hanna-Barbera Production, 1962.

HARRIS, A. J.; HAHN, U. Unrealistic optimism about future life events: A cautionary note. Psychological Review. [S.1.; s.n], V. 118, N. 1, p. 135-154, 2011.

HARRIS, P. R.; GRIFFIN, D. W.; MURRAY, S.. Testing the Limits of Optimistic Bias: Event and Person Moderators in a Multilevel Framework. Journal of Personality and Social Psychology. V. 95, N. 5, p. 1225-1237, 2008.

HARRIS, P. The impact of perceived experience on likelihood judgments for self and others: An experimental approach. European Journal of Social Psychology, V. 37, N. 1, p. 141$151,2007$. 
HELWEG-LARSEN, M.; SHEPPERD, J. A. Do moderators of the optimistic bias affect personal or target risk estimates? A review of the literature. Personality and Social Psychology Review. V. 5, N. 1, p. 74-95, 2001.

HILARY, G.; HSU, C.; SEGAL, B. The Bright Side of Managerial Over-optimism. INSEAD The Business School for the world. Faculty e Research Working Paper. 2013. Disponível em: http://www.insead.edu/facultyresearch/research/doc.cfm?did=52779. Acesso em: 30 Jul. 2014.

IASB. IAS 37 Provisions, Contingent Liabilities and Contingent Assets. 2012. Disponível em: <http://www.ifrs.org/IFRSs/Documents/English\%20IAS\%20and\%20IFRS\%20PDFs\% 202012/IAS\%2037.pdf>. Acesso em: 30 Jul. 2014.

IASB. The Conceptual Framework for Financial Reporting. London: IFRS Foundation Publications Department, 2010.

INVESTOR PERSPECTIVES. A tale of "prudence". Disponível em: $<$ http://www.ifrs.org/ Investor-resources/Investor-perspectives-2/Documents/Prudence_Investor-Perspective _Conceptual-FW.PDF>. Acesso em: 15 Jun. 2015.

KOONCE, L.; MERCER, M. Using Psychology Theories in Archival Financial Accounting Research. Journal of Accounting Literature, [S.1.; s.n], V. 24, p. 175-214, 2005.

KUHNEN, C.M.; KNUTSON, B. The Neural Basis of Financial Risk Taking. Neuron, [S.l.; s.n], V. 47, N. 5, p. 763-770, 2005.

LIBBY, R.; BLOOMFIELD, R.; NELSON, M. W. Experimental research in financial accounting. Accounting, Organizations and Society, V. 27, N. 8, p. 775-810, 2002.

MACHADO, Thalyson Renan Bitencourt; SOUZA, Kamyr Gomes de; COSTA, PATRÍCIA DE SOUZA. Efeitos do Conservadorismo no Reconhecimento Contábil de Provisões após o Pronunciamento Técnico CPC 25 XV Congresso USP de Contabilidade e Controladoria. São Paulo, 29 a 31 de julho de 2015.

MARTIN, Nilton Cano, SANTOS, Lílian Regina dos, DIAS FILHO, José Maria. GOVERNANÇA EMPRESARIAL, RISCOS E CONTROLES INTERNOS: A EMERGÊNCIA DE UM NOVO MODELO DE CONTROLADORIA. Revista Contabilidade \& Finanças - USP, São Paulo, n. 34, p. 7 - 22, janeiro/abril 2004.

MASINI, A. A. M. Fatores de personalidade e Percepção de Riscos pode m predizer o comportamento de risco? Um estudo com universitários. 2009.186f. Dissertação (Mestrado em Psicologia)-Instituto de Psicologia, Universidade Federal de Uberlândia, Uberlândia, 2009.

MOONITZ, M. The basic postulates of accounting. Accounting Research Study, 1, New York: AICPA, 1961.

MOORE, K. A.. Quasi-experimental evaluations. Washington: Child Trends. [S.l.; s.n], 2008.

PETERSON, C. The Future of Optimism. American Psychological Association. [S.1.; s.n], V. 55, N. 1, p. 44-55, 2000. 
POMPIAN, MICHAEL M. Behavioral Finance and Wealth Management How to Build Optimal Portfolios That Account for Investor Biases Published by John Wiley \& Sons, Inc., Hoboken, New Jersey. 2006.

POPA, Irimie Emil; TUDOR, Adriana Tiron; SPAN, Georgeta Ancuta; FULOP, Melinda Timea. Essential Characteristics of a correct prefessional judgment process. International Journal of Business Research. [S.1.; s.n], Vol.11, n 1, 2011.

PORTELLA, Anastácia Rosa; OLIVEIRA, Monique Cristiane de; ELIAS, Thayse Moraes ; LORANDI, Joisse Antonio. Passivos contingentes: um estudo nas maiores companhias abertas do estado de Santa Catarina/SC. RIGC - Vol. XIII, nº 25, Enero-Junio 2015, Universidade Federal de Santa Catarina - UFSC

PRADO, F.J. Análise do comportamento da divulgação das informações sobre provisões e passivos contingentes das empresas do setor de energia elétrica listadas na BM\&FBOVESPA. Dissertação (Mestrado Controladoria e Contabilidade) - Faculdade de Economia, Administração e Contabilidade de Ribeirão Preto da Universidade de São Paulo, 2014.

PREACHER, K. J. Extreme groups designs. In R. L. Cautin \& S. O. Lilienfeld (Eds.), The encyclopedia of clinical psychology, [S.1.; s.n], Vol. 2, pp. 1189-1192,. Hoboken, NJ: John Wiley \& Sons, Inc., 2015.

PURI, M.; ROBINSON, D. T. Optimism and economic choice. Journal of Financial Economics. [S.1.; s.n], V. 86, N. 6, p. 71-99, 2007.

REPRESENTAÇÃO Fidedigna pelo Prof. Eliseu Martins. Produzido por: Fundação FIPECAFI, 2’21'. 2013. Disponível em: < http://www.youtube.com/watch?v=CX1Crlzt0Jg $>$. Acesso em: 10 dez. de 2013.

REYNA, Valerie F., RIVERS, Susan E. Current Theories of Risk and Rational Decision Making. Dev Rev. 2008 March ; Vol. 28, n.1, pp.: 1-11. NIH Public Access

RIBEIRO, A. C., RIBEIRO, M. S., WEFFORT E. F. J. (2013). Provisões, contingências e pronunciamento CPC 25: as percepções dos protagonistas envolvidos. Revista Universo Contábil, [S.1.; s.n], vol. 9, n.3, 38-54.

RIBEIRO, Antonio de Cístolo. Provisões, contingências e normas contábeis:.um estudo de gerenciamento de resultados com contencioso legal no Brasil. Dissertação (Mestrado Controladoria e Contabilidade ). Faculdade de Economia, Administração e Contabilidade Ribeirão Preto/USP. 2012.

RUMEL, D. “Odds ratio”: algumas considerações. Rev. Saúde Pública, São Paulo, [S.n.], v. 20, n. 3, Jun, 1986.

SALOTTI, B.; YAMAMOTO, M. Ensaio sobre a teoria da divulgação. Brazilian Business. Review, [S.1.; s.n], v. 2, n. 1, p. 53-70, 2005.

SCHEIER, M. F., CARVER, C. S., BRIDGES, M. W. Distinguishing optimism from neuroticism (and trait anxiety, self-mastery, and self-esteem): A re-evaluation of the Life Orientation Test. Journal of Personality and Social Psychology. 67, 1063-1078, 1994. 
SCHEIER, M. F.; CARVER , C. S. Dispositional optimism and physical well-being: the influence of generalized expectancies on health. Journal of Personality. V. 55, N. 2, p. 169$210,1987$.

SCHEIER, M. F.; CARVER, Charles S.. Optimism, Coping, and Health: Assessment and Implications of Generalized Outcome Expectancies. Health Psychology, [S.l.; s.n], V.4, n. 3, p. 219-247, 1985.

SHADISH, W. R.; COOK, T. D.; CAMPBELL, D. T. Experimental and QuasiExperimental designs for generalized causal inference. Houghton Mifflin Company, New York: 2002.

SHAROT, T. The optimism bias. Current Biology, [S.1.; s.n], V. 21, p.941-945, 2011.

SHAROT, T.; et al. Neural mechanisms mediating optimism bias. Nature Neurosciense 450, p. 102-105, 2007.

SHEPPERD, J. A. et al. Anxiety and outcome predictions Personality and Social Psychology Bulletin, V. 31, N. 2, p. 267-275, 2005.

SHEPPERD, J. A. et al. Taking Stock of Unrealistic Optimism. Perspectives on Psychological Science, V. 8, N. 4, p. 395-411, 2013.

SHEPPERD, J. A.; OUELLETTE, J. A.; FERNANDEZ, J. K. Abandoning unrealistic optimism: Performance estimates and the temporal proximity of self-relevant feedback. Journal of Personality and Social Psychology, V. 70, N. 4, p. 844-855, 1996.

SHILLER, R. J. Irrational Exuberance. Princeton University Press, Princeton, New Jersey, 2000.

SUAVE, R.; CODESSO, M.M.; PINTO, H.M.; VICENTE, E.F.R.; LUNKES, R.J.:

Divulgação de passivos contingentes nas empresas mais líquidas da BM\&FBovespa. Revista da UNIFEBE, Vol.1, n. 11, p.1-17, 2013.

SVENSON, Ola. Are we all less risky and more skillful than our Fellow drivers? Acta Psychologica, vol. 47, 143-148,1981.

TODOROV, João Claudio; COELHO, Cristiano; HANNA, Elenice S. O que, como e porque escolher. Univerciência, Brasília, [S.n.], mai, 2003.

TODOROV, João Claudio; MOREIRA, Márcio Borges. O Conceito de Motivação na Psicologia. Revista Brasileira de Terapia Comportamental e Cognitiva. 2005, Vol. VII, $\mathrm{n}^{\circ}$ 1, p. 119-132.

TROTMAN, Ken T., TAN, Hwee C., ANG, Nicole. Fifty-year overview of judgment and decision-making research in accounting. Accounting and Finance, Vol 51, 278-360, 2011.

UCBASARAN, D. et al. The nature of entrepreneurial experience, business failure and comparative optimism . Journal of Business Venturing, [S.1.; s.n], V.25, 541-555, 2010. 
VALERDI, R.; BLACKBURN, C.. Human Element of Decision Making in Systems Engineers: A Focus on Optimism. MIT Sociotechnical Systems Research Center (SSRC), 2009.

VERRECCHIA, R. E. Essays on disclosure. Journal of Accounting and Economics, v. 22, n. 32 p. $97-180,2001$.

VIVIANI, Sueli; FERNANDES, Francisco Carlos. Qualidade da Evidenciação de Passivos Contingentes Relacionados ao Risco Legal: um estudo em empresas petrolíferas brasileiras, estadunidenses e britânicas. XXXVIII Encontro da ANPAD, Rio de Janeiro, 13 a 17 de Set. 2014.

WATTS, R. L. Conservatism in accounting part I: explanations and implications. Accounting Horizons, V. 17, N. 3, p. 207-221, 2003.

WEINSTEIN, N. D. Unrealistic optimism about future life events. Journal of Personality and Social Psychology, [S.1.; s.n], V. 39, N. 5, p. 806-882, 1980.

WEINSTEIN, N. D. Unrealistic optimism about susceptibility to health problems:

Conclusions from a community-wide sample. Journal of Behavioral Medicine, [S.l.; s.n], V. 10, p. 481-500, 1987.

WEINSTEIN, N. D.; KLEIN, W. M. Resistance of personal risk perceptions to debiasing interventions. Health Psychology, [S.1.; s.n], V. 14, N. 2, p. 132-140, 1996. 


\section{APÊNDICE A - Instrumento de Pesquisa}

\section{Encontro}

"O quanto provável você pensa que cada um dos seguintes eventos pode acontecer na sua vida?"

1- Ganhar R\$ 5.000,00 em um título de capitalização, no qual você tenha investido R\$ 500,00 ;

\begin{tabular}{|c|c|c|c|c|c|c|c|c|c|c|}
\hline \multicolumn{6}{|c|}{ O evento certamente não acontecerá } & & \multicolumn{4}{|c|}{ O evento certamente acontecera } \\
\hline 0 & 1 & 2 & 3 & 4 & 5 & 6 & 7 & 8 & 9 & 10 \\
\hline
\end{tabular}

2- Fazer viagem internacional pelo menos uma vez ao ano, a partir do ano da sua aposentadoria;

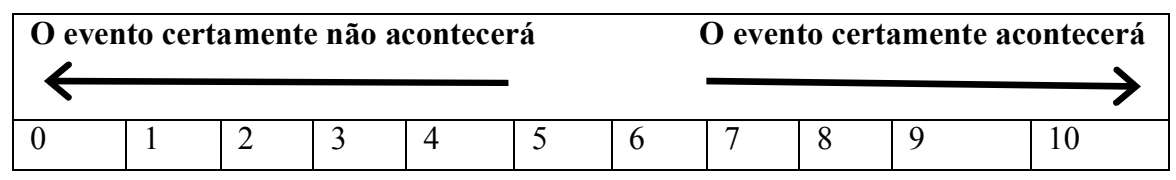

3- Ganhar um prêmio em um sorteio;

\begin{tabular}{|l|l|l|l|l|l|l|l|l|l|l|}
\hline \multicolumn{3}{|c|}{\begin{tabular}{c} 
O evento certamente não acontecerá \\
\cline { 8 - 10 }
\end{tabular}} \\
\hline 0 & 1 & 2 & 3 & 4 & 5 & 6 & 7 & 8 & 9 & 10 \\
\hline
\end{tabular}

4- Comprar uma passagem aérea e receber restituição de valor em função de substituição de vôo

\begin{tabular}{|c|c|c|c|c|c|c|c|c|c|c|}
\hline \multicolumn{6}{|c|}{ O evento certamente não acontecerá } & & \multicolumn{4}{|c|}{ O evento certamente acontecerá } \\
\hline 0 & 1 & 2 & 3 & 4 & 5 & 6 & 7 & 8 & 9 & 10 \\
\hline
\end{tabular}

5- Auferir ganhos decorrentes de investimentos selecionados a partir da divulgação de sua rentabilidade

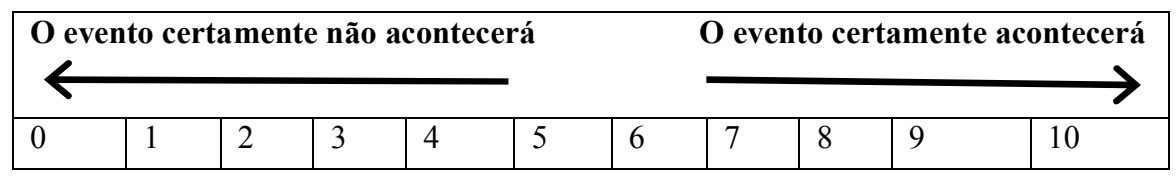

6- Ser demitido de um emprego privado após crise do setor no qual está inserido;

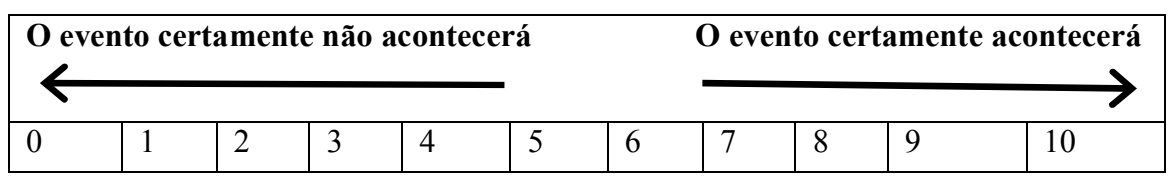

7- Ficar desempregado por mais de seis meses; 


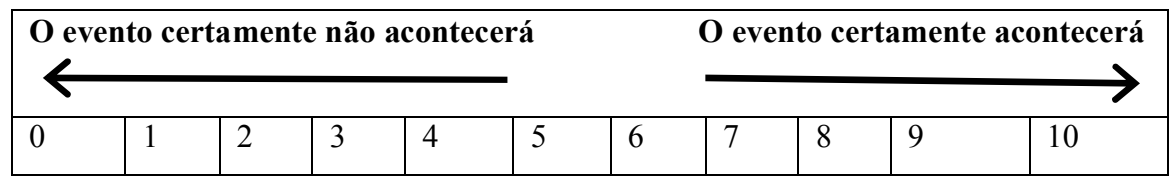

8- Pagar uma multa decorrente de processo no qual não cabe mais recurso;

\begin{tabular}{|l|l|l|l|l|l|l|l|l|l|l|}
\hline \multicolumn{3}{|c}{\begin{tabular}{c} 
O evento certamente não acontecerá \\
\cline { 7 - 9 }
\end{tabular}} \\
\hline 0 & 1 & 2 & 3 & 4 & 5 & 6 & 7 & 8 & 9 & 10 \\
\hline
\end{tabular}

9- Perder os pertences (celular, óculos e relógio) em função de um assalto;

\begin{tabular}{|c|c|c|c|c|c|c|c|c|c|c|}
\hline \multicolumn{7}{|c|}{ O evento certamente não acontecerá } & \multicolumn{4}{|c|}{ O evento certamente acontecerá } \\
\hline 0 & 1 & 2 & 3 & 4 & 5 & T & 7 & 8 & 9 & 10 \\
\hline
\end{tabular}

10- Compra de um imóvel na planta, o qual apresenta desvalorização na data da entrega;

\begin{tabular}{|c|c|c|c|c|c|c|c|c|c|c|}
\hline \multicolumn{7}{|c|}{ O evento certamente não acontecerá } & \multicolumn{4}{|c|}{ O evento certamente acontecerá } \\
\hline 0 & 1 & 2 & 3 & 4 & 5 & 6 & 7 & 8 & 9 & 10 \\
\hline
\end{tabular}

\section{“O quanto você pensa que tem de controle sobre cada um dos seguintes eventos?”;}

1- Ganhar R\$ 5.000,00 em um título de capitalização, no qual você tenha investido R\$ 500,00 ;

\begin{tabular}{|c|c|c|c|c|c|c|c|c|c|c|c|}
\hline Fator Moderador & 0 & 1 & 2 & 3 & 4 & 5 & 6 & 7 & 8 & 9 & 10 \\
\hline Controle do Evento & & Po & $\mathrm{OC}$ & ntro & & & & & ontr & le $\mathrm{C}$ & leto \\
\hline
\end{tabular}

2- Fazer viagem internacional pelo menos uma vez ao ano, a partir do ano da sua aposentadoria;

\begin{tabular}{|l|c|c|c|c|c|c|c|c|c|c|c|}
\hline Fator Moderador & 0 & 1 & 2 & 3 & 4 & 5 & 6 & 7 & 8 & 9 & 10 \\
\hline Controle do Evento & \multicolumn{10}{|l|}{ Muito Pouco Controle } \\
& \multicolumn{4}{|l|}{} \\
\hline
\end{tabular}

3- Ganhar um prêmio em um sorteio;

\begin{tabular}{|l|c|c|c|c|c|c|c|c|c|c|c|}
\hline Fator Moderador & 0 & 1 & 2 & 3 & 4 & 5 & 6 & 7 & 8 & 9 & 10 \\
\hline Controle do Evento & \multicolumn{10}{|l|}{ Muito Pouco Controle } \\
& \multicolumn{4}{|l}{} \\
\hline
\end{tabular}

4- Comprar uma passagem aérea e receber restituição de valor em função de substituição de vôo;

\begin{tabular}{|l|l|l|l|l|l|l|l|l|l|l|l|}
\hline Fator Moderador & 0 & 1 & 2 & 3 & 4 & 5 & 6 & 7 & 8 & 9 & 10 \\
\hline
\end{tabular}




\begin{tabular}{|l|ll|}
\hline Controle do Evento & Muito Pouco Controle & Controle Completo \\
\hline
\end{tabular}

5- Auferir ganhos decorrentes de investimentos selecionados a partir da divulgação de sua rentabilidade;

\begin{tabular}{|l|c|c|c|c|c|c|c|c|c|c|c|}
\hline Fator Moderador & 0 & 1 & 2 & 3 & 4 & 5 & 6 & 7 & 8 & 9 & 10 \\
\hline Controle do Evento & \multicolumn{10}{|l|}{ Controle Completo } \\
& \multicolumn{1}{|l|}{} \\
\hline
\end{tabular}

6- Ser demitido de um emprego privado após crise do setor no qual está inserido;

\begin{tabular}{|l|c|c|c|c|c|c|c|c|c|c|c|}
\hline Fator Moderador & 0 & 1 & 2 & 3 & 4 & 5 & 6 & 7 & 8 & 9 & 10 \\
\hline Controle do Evento & \multicolumn{10}{|l|}{ Controle Completo } \\
& \multicolumn{4}{|l}{} \\
\hline
\end{tabular}

7- Ficar desempregado por mais de seis meses;

\begin{tabular}{|l|c|c|c|c|c|c|c|c|c|c|c|}
\hline Fator Moderador & 0 & 1 & 2 & 3 & 4 & 5 & 6 & 7 & 8 & 9 & 10 \\
\hline Controle do Evento & \multicolumn{10}{|l|}{ Controle Completo } \\
& \multicolumn{1}{|l}{} \\
\hline
\end{tabular}

8- Pagar uma multa decorrente de processo no qual não cabe mais recurso;

\begin{tabular}{|l|c|c|c|c|c|c|c|c|c|c|c|}
\hline Fator Moderador & 0 & 1 & 2 & 3 & 4 & 5 & 6 & 7 & 8 & 9 & 10 \\
\hline Controle do Evento & \multicolumn{10}{|c|}{ Controle Completo } \\
& \multicolumn{4}{|l}{} \\
\hline
\end{tabular}

9- Perder os pertences (celular, óculos e relógio) em função de um assalto;

\begin{tabular}{|l|c|c|c|c|c|c|c|c|c|c|c|}
\hline Fator Moderador & 0 & 1 & 2 & 3 & 4 & 5 & 6 & 7 & 8 & 9 & 10 \\
\hline Controle do Evento & \multicolumn{10}{|l|}{ Controle Completo } \\
& \multicolumn{1}{|l|}{} \\
\hline
\end{tabular}

10- Compra de um imóvel na planta, o qual apresenta desvalorização na data da entrega;

\begin{tabular}{|l|c|c|c|c|c|c|c|c|c|c|c|}
\hline Fator Moderador & 0 & 1 & 2 & 3 & 4 & 5 & 6 & 7 & 8 & 9 & 10 \\
\hline Controle do Evento & \multicolumn{10}{|l|}{ Controle Completo } \\
& \multicolumn{4}{|l|}{} \\
\hline
\end{tabular}

“Indique o quanto de experiência você tem sobre cada um dos seguintes eventos?”; 
1- Ganhar R\$ 5.000,00 em um título de capitalização, no qual você tenha investido R\$ 500,00

\begin{tabular}{|c|c|c|c|c|c|c|c|c|c|c|c|}
\hline Fator Moderador & 0 & 1 & 2 & 3 & 4 & 5 & 6 & 7 & 8 & 9 & 10 \\
\hline Experiência Pessoal Prévia & & Pou & $\mathrm{a} \mathrm{Ex}_{\mathrm{x}}$ & eri & & & & & iita & xpe & \\
\hline
\end{tabular}

2- Fazer viagem internacional pelo menos uma vez ao ano, a partir do ano da sua aposentadoria;

\begin{tabular}{|c|c|c|c|c|c|c|c|c|c|c|c|}
\hline Fator Moderador & 0 & 1 & 2 & 3 & 4 & 5 & 6 & 7 & 8 & 9 & 10 \\
\hline Experiência Pessoal Prévia & & Po & $\mathrm{aE}$ & eriế & & & & & iita & $\operatorname{xpe}$ & \\
\hline
\end{tabular}

3- Ganhar um prêmio em um sorteio;

\begin{tabular}{|l|c|c|c|c|c|c|c|c|c|c|c|}
\hline Fator Moderador & 0 & 1 & 2 & 3 & 4 & 5 & 6 & 7 & 8 & 9 & 10 \\
\hline Experiência Pessoal Prévia & \multicolumn{1}{|c|}{ Muita Pouca Experiência } \\
& \multicolumn{1}{|c|}{ Muita Experiência } \\
\end{tabular}

4- Comprar uma passagem aérea e receber restituição de valor em função de substituição de vôo;

\begin{tabular}{|l|c|c|c|c|c|c|c|c|c|c|c|}
\hline Fator Moderador & 0 & 1 & 2 & 3 & 4 & 5 & 6 & 7 & 8 & 9 & 10 \\
\hline Experiência Pessoal Prévia & \multicolumn{10}{|c|}{ Muita Pouca Experiência } \\
& \multicolumn{1}{|c}{} \\
\hline
\end{tabular}

5- Auferir ganhos decorrentes de investimentos selecionados a partir da divulgação de sua rentabilidade;

\begin{tabular}{|l|c|c|c|c|c|c|c|c|c|c|c|}
\hline Fator Moderador & 0 & 1 & 2 & 3 & 4 & 5 & 6 & 7 & 8 & 9 & 10 \\
\hline Experiência Pessoal Prévia & \multicolumn{1}{|c|}{$\begin{array}{l}\text { Muita Pouca Experiência } \\
\end{array}$} \\
\hline
\end{tabular}

6- Ser demitido de um emprego privado após crise do setor no qual está inserido;

\begin{tabular}{|l|c|c|c|c|c|c|c|c|c|c|c|}
\hline Fator Moderador & 0 & 1 & 2 & 3 & 4 & 5 & 6 & 7 & 8 & 9 & 10 \\
\hline Experiência Pessoal Prévia & \multicolumn{1}{|c|}{ Muita Pouca Experiência } \\
& \multicolumn{1}{|c|}{ Muita Experiência } \\
\end{tabular}

7- Ficar desempregado por mais de seis meses; 


\begin{tabular}{|l|c|c|c|c|c|c|c|c|c|c|c|}
\hline Fator Moderador & 0 & 1 & 2 & 3 & 4 & 5 & 6 & 7 & 8 & 9 & 10 \\
\hline Experiência Pessoal Prévia & \multicolumn{10}{|c|}{ Muita Pouca Experiência } \\
& \multicolumn{10}{|c|}{} \\
\hline
\end{tabular}

8- Pagar uma multa decorrente de processo no qual não cabe mais recurso;

\begin{tabular}{|l|c|c|c|c|c|c|c|c|c|c|c|}
\hline Fator Moderador & 0 & 1 & 2 & 3 & 4 & 5 & 6 & 7 & 8 & 9 & 10 \\
\hline Experiência Pessoal Prévia & \multicolumn{10}{|c|}{ Muita Pouca Experiência } \\
& \multicolumn{10}{|c|}{} \\
\hline
\end{tabular}

9- Perder os pertences (celular, óculos e relógio) em função de um assalto;

\begin{tabular}{|l|c|c|c|c|c|c|c|c|c|c|c|}
\hline Fator Moderador & 0 & 1 & 2 & 3 & 4 & 5 & 6 & 7 & 8 & 9 & 10 \\
\hline Experiência Pessoal Prévia & \multicolumn{10}{|c|}{ Muita Pouca Experiência Experiência } \\
& \multicolumn{10}{|c|}{} \\
\hline
\end{tabular}

10- Compra de um imóvel na planta, o qual apresenta desvalorização na data da entrega;

\begin{tabular}{|l|c|c|c|c|c|c|c|c|c|c|c|}
\hline Fator Moderador & 0 & 1 & 2 & 3 & 4 & 5 & 6 & 7 & 8 & 9 & 10 \\
\hline Experiência Pessoal Prévia & \multicolumn{10}{|c|}{ Muita Pouca Experiência Experiência } \\
& \multicolumn{10}{|c|}{} \\
\hline
\end{tabular}

\section{Final da Manhã}

"Pense um indivíduo médio, de mesmo sexo e idade que você, o quanto provável você acha que cada um dos eventos seguintes pode acontecer a essa pessoa no futuro?"

11- Ganhar R $\$ 5.000,00$ em um título de capitalização, no qual você tenha investido R\$ 500,00 ;

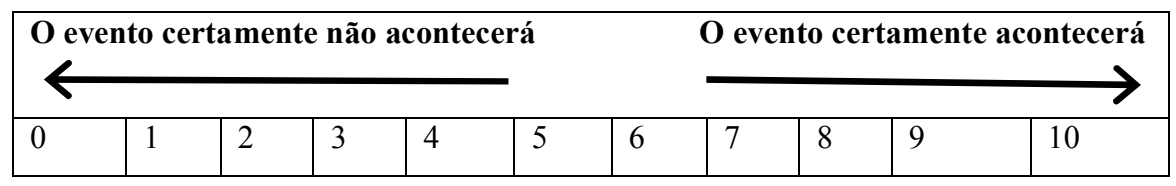

12- Fazer viagem internacional pelo menos uma vez ao ano, a partir do ano da sua aposentadoria;

\begin{tabular}{|c|c|c|c|c|c|c|c|c|c|c|}
\hline \multicolumn{6}{|c|}{ O evento certamente não acontecerá } & & \multicolumn{4}{|c|}{ O evento certamente acontecerá } \\
\hline 0 & 1 & 2 & 3 & 4 & 5 & 6 & 7 & 8 & 9 & 10 \\
\hline
\end{tabular}

13- Ganhar um prêmio em um sorteio; 


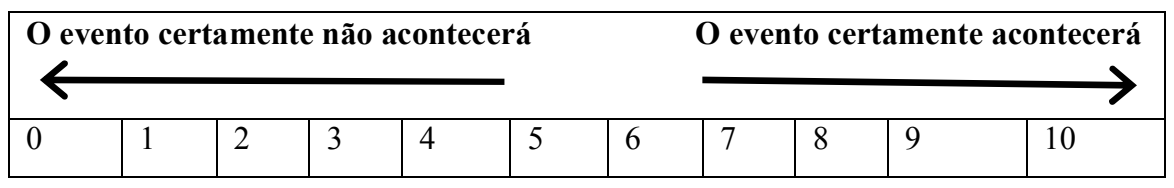

14- Comprar uma passagem aérea e receber restituição de valor em função de substituição de vôo

\begin{tabular}{|l|l|l|l|l|l|l|l|l|l|l|}
\hline \multicolumn{3}{|c}{\begin{tabular}{c} 
O evento certamente não acontecerá \\
\cline { 7 - 9 }
\end{tabular}} \\
\hline 0 & 1 & 2 & 3 & 4 & 5 & 6 & 7 & 8 & 9 & 10 \\
\hline
\end{tabular}

15- Auferir ganhos decorrentes de investimentos selecionados a partir da divulgação de sua rentabilidade

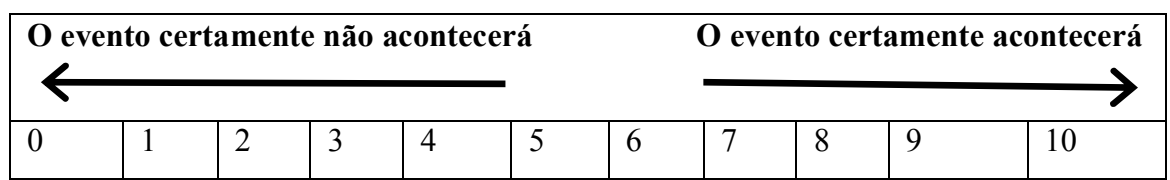

16- Ser demitido de um emprego privado após crise do setor no qual está inserido;

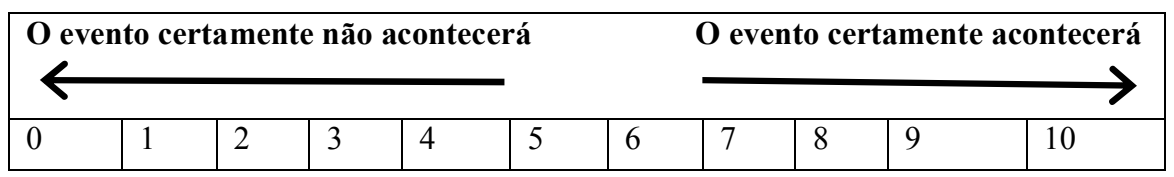

17- Ficar desempregado por mais de seis meses;

\begin{tabular}{|c|c|c|c|c|c|c|c|c|c|c|}
\hline \multicolumn{6}{|c|}{ O evento certamente não acontecerá } & & \multicolumn{4}{|c|}{ O evento certamente acontecerá } \\
\hline 0 & 1 & 2 & 3 & 4 & 5 & 6 & 7 & 8 & 9 & 10 \\
\hline
\end{tabular}

18- Pagar uma multa decorrente de processo no qual não cabe mais recurso;

\begin{tabular}{|c|c|c|c|c|c|c|c|c|c|c|}
\hline \multicolumn{6}{|c|}{ O evento certamente não acontecerá } & & \multicolumn{4}{|c|}{ O evento certamente acontecerá } \\
\hline 0 & 1 & 2 & 3 & 4 & 5 & 6 & 7 & 8 & T & 10 \\
\hline
\end{tabular}

19- Perder os pertences (celular, óculos e relógio) em função de um assalto;

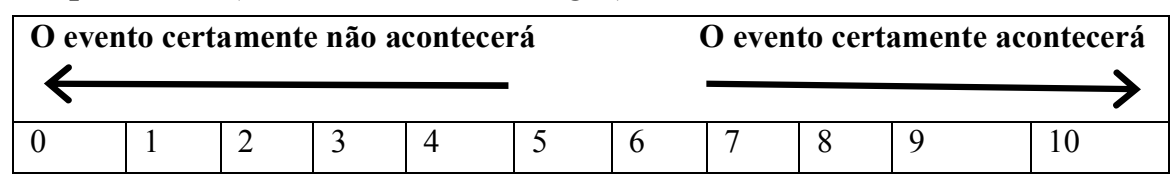

20- Compra de um imóvel na planta, o qual apresenta desvalorização na data da entrega; 


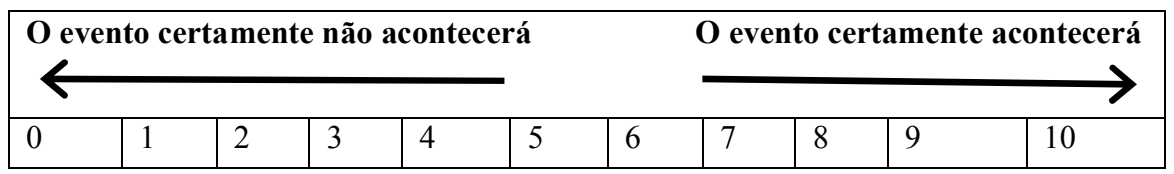

"O quanto você pensa que um indivíduo médio, de mesmo sexo e idade têm de controle sobre cada um dos seguintes eventos?";

11- Ganhar R\$ 5.000,00 em um título de capitalização, no qual você tenha investido R\$ 500,00 ;

\begin{tabular}{|l|c|c|c|c|c|c|c|c|c|c|c|}
\hline Fator Moderador & 0 & 1 & 2 & 3 & 4 & 5 & 6 & 7 & 8 & 9 & 10 \\
\hline Controle do Evento & \multicolumn{1}{|c|}{ Controle Completo } \\
& \multicolumn{4}{|l|}{} \\
\hline
\end{tabular}

12- Fazer viagem internacional pelo menos uma vez ao ano, a partir do ano da sua aposentadoria;

\begin{tabular}{|l|c|c|c|c|c|c|c|c|c|c|c|}
\hline Fator Moderador & 0 & 1 & 2 & 3 & 4 & 5 & 6 & 7 & 8 & 9 & 10 \\
\hline Controle do Evento & \multicolumn{1}{|c|}{ Controle Completo } \\
& \multicolumn{4}{|l|}{} \\
\cline { 1 - 2 }
\end{tabular}

13- Ganhar um prêmio em um sorteio;

\begin{tabular}{|l|c|c|c|c|c|c|c|c|c|c|c|}
\hline Fator Moderador & 0 & 1 & 2 & 3 & 4 & 5 & 6 & 7 & 8 & 9 & 10 \\
\hline Controle do Evento & \multicolumn{10}{|l|}{ Controle Completo } \\
& \multicolumn{4}{|l|}{} \\
\hline
\end{tabular}

14- Comprar uma passagem aérea e receber restituição de valor em função de substituição de vôo;

\begin{tabular}{|l|c|c|c|c|c|c|c|c|c|c|c|}
\hline Fator Moderador & 0 & 1 & 2 & 3 & 4 & 5 & 6 & 7 & 8 & 9 & 10 \\
\hline Controle do Evento & \multicolumn{1}{|c|}{ Controle Completo } \\
& \multicolumn{4}{|l|}{} \\
\hline
\end{tabular}

15- Auferir ganhos decorrentes de investimentos selecionados a partir da divulgação de sua rentabilidade;

\begin{tabular}{|l|c|c|c|c|c|c|c|c|c|c|c|}
\hline Fator Moderador & 0 & 1 & 2 & 3 & 4 & 5 & 6 & 7 & 8 & 9 & 10 \\
\hline Controle do Evento & \multicolumn{1}{|c|}{ Cuito Pouco Controle } \\
& \multicolumn{1}{|l|}{} \\
\hline
\end{tabular}

16- Ser demitido de um emprego privado após crise do setor no qual está inserido;

\begin{tabular}{|l|c|c|c|c|c|c|c|c|c|c|c|}
\hline Fator Moderador & 0 & 1 & 2 & 3 & 4 & 5 & 6 & 7 & 8 & 9 & 10 \\
\hline Controle do Evento & \multicolumn{1}{|l|}{ Controle Completo } \\
& \multicolumn{4}{|l|}{} \\
\hline
\end{tabular}


17- Ficar desempregado por mais de seis meses;

\begin{tabular}{|l|c|c|c|c|c|c|c|c|c|c|c|}
\hline Fator Moderador & 0 & 1 & 2 & 3 & 4 & 5 & 6 & 7 & 8 & 9 & 10 \\
\hline Controle do Evento & \multicolumn{10}{|l|}{ Controle Completo } \\
& \multicolumn{4}{|l|}{} \\
\hline
\end{tabular}

18- Pagar uma multa decorrente de processo no qual não cabe mais recurso;

\begin{tabular}{|l|c|c|c|c|c|c|c|c|c|c|c|}
\hline Fator Moderador & 0 & 1 & 2 & 3 & 4 & 5 & 6 & 7 & 8 & 9 & 10 \\
\hline Controle do Evento & \multicolumn{1}{|c|}{ Controle Completo } \\
& \multicolumn{4}{|l|}{} \\
\hline
\end{tabular}

19- Perder os pertences (celular, óculos e relógio) em função de um assalto;

\begin{tabular}{|c|c|c|c|c|c|c|c|c|c|c|c|}
\hline Fator Moderador & 0 & 1 & 2 & 3 & 4 & 5 & 6 & 7 & 8 & 9 & 10 \\
\hline Controle do Evento & \multicolumn{11}{|c|}{ Muito Pouco Controle Controle Completo } \\
\hline
\end{tabular}

20- Compra de um imóvel na planta, o qual apresenta desvalorização na data da entrega;

\begin{tabular}{|l|c|c|c|c|c|c|c|c|c|c|c|}
\hline Fator Moderador & 0 & 1 & 2 & 3 & 4 & 5 & 6 & 7 & 8 & 9 & 10 \\
\hline Controle do Evento & \multicolumn{10}{|l|}{ Controle Completo } \\
& \multicolumn{4}{|l}{} \\
\hline
\end{tabular}

\section{"Indique quanto você pensa que um indivíduo médio, de mesmo sexo e idade têm de experiência sobre cada um dos seguintes eventos?”}

11- Ganhar R \$ 5.000,00 em um título de capitalização, no qual você tenha investido R\$ 500,00 ;

\begin{tabular}{|l|c|c|c|c|c|c|c|c|c|c|c|}
\hline Fator Moderador & 0 & 1 & 2 & 3 & 4 & 5 & 6 & 7 & 8 & 9 & 10 \\
\hline Experiência Pessoal Prévia & \multicolumn{10}{|c|}{ Muita Pouca Experiência } \\
& \multicolumn{10}{|c|}{} \\
\hline
\end{tabular}

12- Fazer viagem internacional pelo menos uma vez ao ano, a partir do ano da sua aposentadoria;

\begin{tabular}{|l|c|c|c|c|c|c|c|c|c|c|c|}
\hline Fator Moderador & 0 & 1 & 2 & 3 & 4 & 5 & 6 & 7 & 8 & 9 & 10 \\
\hline Experiência Pessoal Prévia & \multicolumn{10}{|c|}{ Muita Pouca Experiência } \\
& \multicolumn{4}{|c|}{} \\
\hline
\end{tabular}


13- Ganhar um prêmio em um sorteio;

\begin{tabular}{|l|c|c|c|c|c|c|c|c|c|c|c|}
\hline Fator Moderador & 0 & 1 & 2 & 3 & 4 & 5 & 6 & 7 & 8 & 9 & 10 \\
\hline Experiência Pessoal Prévia & \multicolumn{10}{|c|}{ Muita Pouca Experiência } \\
& \multicolumn{1}{|c|}{} \\
\hline
\end{tabular}

14- Comprar uma passagem aérea e receber restituição de valor em função de substituição de vôo;

\begin{tabular}{|l|c|c|c|c|c|c|c|c|c|c|c|}
\hline Fator Moderador & 0 & 1 & 2 & 3 & 4 & 5 & 6 & 7 & 8 & 9 & 10 \\
\hline Experiência Pessoal Prévia & \multicolumn{10}{|c|}{ Muita Pouca Experiência } \\
& \multicolumn{11}{|c|}{} \\
\hline
\end{tabular}

15- Auferir ganhos decorrentes de investimentos selecionados a partir da divulgação de sua rentabilidade;

\begin{tabular}{|l|c|c|c|c|c|c|c|c|c|c|c|}
\hline Fator Moderador & 0 & 1 & 2 & 3 & 4 & 5 & 6 & 7 & 8 & 9 & 10 \\
\hline Experiência Pessoal Prévia & \multicolumn{10}{|c|}{ Muita Pouca Experiência } \\
& \multicolumn{10}{|c|}{} \\
\hline
\end{tabular}

16- Ser demitido de um emprego privado após crise do setor no qual está inserido;

\begin{tabular}{|l|c|c|c|c|c|c|c|c|c|c|c|}
\hline Fator Moderador & 0 & 1 & 2 & 3 & 4 & 5 & 6 & 7 & 8 & 9 & 10 \\
\hline Experiência Pessoal Prévia & \multicolumn{10}{|c|}{ Muita Pouca Experiência Experiência } \\
& \multicolumn{10}{|c|}{} \\
\hline
\end{tabular}

17- Ficar desempregado por mais de seis meses;

\begin{tabular}{|l|c|c|c|c|c|c|c|c|c|c|c|}
\hline Fator Moderador & 0 & 1 & 2 & 3 & 4 & 5 & 6 & 7 & 8 & 9 & 10 \\
\hline Experiência Pessoal Prévia & \multicolumn{10}{|c|}{ Muita Experiência } \\
& \multicolumn{4}{|c}{} \\
\hline
\end{tabular}

18- Pagar uma multa decorrente de processo no qual não cabe mais recurso;

\begin{tabular}{|l|c|c|c|c|c|c|c|c|c|c|c|}
\hline Fator Moderador & 0 & 1 & 2 & 3 & 4 & 5 & 6 & 7 & 8 & 9 & 10 \\
\hline Experiência Pessoal Prévia & \multicolumn{10}{|c|}{ Muita Pouca Experiência Experiência } \\
& \multicolumn{10}{|c|}{} \\
\cline { 1 - 1 }
\end{tabular}

19- Perder os pertences (celular, óculos e relógio) em função de um assalto;

\begin{tabular}{|l|c|c|c|c|c|c|c|c|c|c|c|}
\hline Fator Moderador & 0 & 1 & 2 & 3 & 4 & 5 & 6 & 7 & 8 & 9 & 10 \\
\hline Experiência Pessoal Prévia & \multicolumn{10}{|c|}{ Muita Pouca Experiência } \\
& \multicolumn{10}{|c|}{} \\
\hline
\end{tabular}


20- Compra de um imóvel na planta, o qual apresenta desvalorização na data da entrega;

\begin{tabular}{|l|c|c|c|c|c|c|c|c|c|c|c|}
\hline Fator Moderador & 0 & 1 & 2 & 3 & 4 & 5 & 6 & 7 & 8 & 9 & 10 \\
\hline Experiência Pessoal Prévia & \multicolumn{1}{|c|}{ Muita Pouca Experiência } \\
& \multicolumn{1}{|c|}{} \\
\hline
\end{tabular}

\section{ENCONTRO}

Grupo Experimental A:

Variável de Controle: Forma de Contratação - CONTRATADO EXTERNAMENTE

Outras Variáveis são mantidas inalteradas

\begin{tabular}{|l|l|}
\hline Quanto à fonte adicional de informação & Advindo da Administração \\
\hline Quanto à existência de fiscalização da tarefa & Sem Fiscalização \\
\hline
\end{tabular}

A empresa Moura tem como atividade preponderante àquelas relacionadas ao transporte de dejetos e está sujeita às exigências associadas com a proteção ao meio ambiente, bem como, a remediação de locais contaminados.

A administração da empresa estima regularmente as contingências, obrigações e compromissos para a remediação de locais contaminados. Nesse contexto, foi verificado no período corrente que os dejetos lançados no terreno atingem o limite imposto pela legislação. Acima desse, a lei obriga o uso de novas tecnologias para a recuperação de locais que sofreram degradação, o que demandaria para a empresa novos investimentos.

Com base em informações levantadas pela própria administração, a lei que trata desses limites está em discussão. A proposta da lei é que haja um aumento desse limite atual. Há fortes indícios que essa mudança esteja bem próxima de acontecer. No entanto, existe uma forte pressão por parte dos ambientalistas, os quais questionam os limites atuais, propondo inclusive uma diminuição dos mesmos. Além dessa discussão, os órgãos de proteção ao meio ambiente também entraram com um pedido de revisão dos limites atuais contrapondo as duas partes acima destacadas. Atualmente, o impasse encontra-se em discussão e depende do sistema judicial. O desfecho refere-se à alteração do limite de dejetos atualmente lançados ao solo; se aumenta ou diminui.

Você trabalha em um escritório de contabilidade, o qual foi contratado pela empresa em questão. Você é o contador da empresa acima descrita, irá assinar e é o responsável direto das demonstrações financeiras elaboradas. Merece destacar que todas as tarefas, registros contábeis e produção de informações, inclusive àquelas evidenciadas nas notas explicativas não sofrem nenhum tipo de fiscalização ou análise.

Sendo assim, é solicitado à você, como contador responsável pela produção das informações contábeis, avaliar a probabilidade de ocorrência do evento acima:

\begin{tabular}{|l|}
\hline ( ) $0 \%$ Nenhuma Probabilidade \\
\hline ( ) Até $10 \%$ \\
\hline ( ) Acima de $10 \%$ até $20 \%$ \\
\hline ( ) Acima de $20 \%$ até $30 \%$ \\
\hline ( ) Acima de $30 \%$ até $40 \%$ \\
\hline ( ) Acima de $40 \%$ até $50 \%$ \\
\hline ( ) Acima de $50 \%$ até $60 \%$ \\
\hline
\end{tabular}




\begin{tabular}{|l|}
\hline ( ) Acima de $60 \%$ até $70 \%$ \\
\hline ( ) Acima de $70 \%$ até $80 \%$ \\
\hline ( ) Acima de $80 \%$ até $90 \%$ \\
\hline
\end{tabular}

Além da contingência acima descrita com possibilidade de perda, a empresa possui uma ação na qual pleiteia a devolução do Imposto de Renda sobre o Lucro Líquido de determinada operação. A empresa em questão é beneficiária dessa compensação e por esse motivo fez o pedido de restituição dos valores recolhidos. $\mathrm{O}$ fisco federal interpôs recurso não concordando com a restituição. No momento atual, o processo está em pendência de julgamento. No entanto, pelas informações publicadas relacionadas a essa reivindicação, existe uma chance do Supremo Tribunal Federal julgar a inconstitucionalidade da ação. Só assim se confirmaria a realização do crédito tributário.

A administração da empresa através de suas análises avalia regularmente suas contingências.

Você trabalha em um escritório de contabilidade, o qual foi contratado pela empresa em questão. Você é o contador da empresa acima descrita, irá assinar e é o responsável direto das demonstrações financeiras elaboradas. Merece destacar que todas as tarefas, registros contábeis e produção de informações, inclusive àquelas evidenciadas nas notas explicativas não sofrem nenhum tipo de fiscalização ou análise.

Sendo assim, você como contador responsável pela produção das informações contábeis, cabe julgar a estimativa relacionada ao desfecho do evento acima exposto.

\begin{tabular}{|l|}
\hline ( ) $0 \%$ Nenhuma Probabilidade \\
\hline ( ) Até $10 \%$ \\
\hline ( ) Acima de $10 \%$ até $20 \%$ \\
\hline ( ) Acima de $20 \%$ até $30 \%$ \\
\hline ( ) Acima de $30 \%$ até $40 \%$ \\
\hline ( ) Acima de $40 \%$ até $50 \%$ \\
\hline ( ) Acima de $50 \%$ até $60 \%$ \\
\hline ( ) Acima de $60 \%$ até $70 \%$ \\
\hline ( ) Acima de $70 \%$ até $80 \%$ \\
\hline ( ) Acima de $80 \%$ até $90 \%$ \\
\hline ( ) Acima de $90 \%$ até $100 \%$ \\
\hline
\end{tabular}

\section{Grupo Experimental B:}

Variável de Controle: Forma de Contratação - A SERVIÇO DE ALGUM ÓRGÃO

Outras Variáveis são mantidas inalteradas

\begin{tabular}{|l|l|}
\hline Quanto à fonte adicional de informação & Advindo da Administração \\
\hline Quanto à existência de fiscalização da tarefa & Sem Fiscalização \\
\hline
\end{tabular}

A empresa Moura tem como atividade preponderante àquelas relacionadas ao transporte de dejetos $\mathrm{e}$ está sujeita às exigências associadas com a proteção ao meio ambiente, bem como, a remediação de locais contaminados.

A administração da empresa estima regularmente as contingências, obrigações e compromissos para a remediação de locais contaminados. Nesse contexto, foi verificado no período corrente que os dejetos lançados no terreno atingem o limite imposto pela legislação. Acima desse, a lei obriga o uso de novas tecnologias para a recuperação de locais que sofreram degradação, o que demandaria para a empresa novos investimentos. 
Com base em informações levantadas pela própria administração, a lei que trata desses limites está em discussão. A proposta da lei é que haja um aumento desse limite atual. Há fortes indícios que essa mudança esteja bem próxima de acontecer. No entanto, existe uma forte pressão por parte dos ambientalistas, os quais questionam os limites atuais, propondo inclusive uma diminuição dos mesmos. Além dessa discussão, os órgãos de proteção ao meio ambiente também entraram com um pedido de revisão dos limites atuais contrapondo as duas partes acima destacadas. Atualmente, o impasse encontra-se em discussão e depende do sistema judicial. $\mathrm{O}$ desfecho refere-se à alteração do limite de dejetos atualmente lançados ao solo; se aumenta ou diminui.

Em função dos problemas acima relatados, a empresa em questão teve que se reportar às resoluções da agência nacional do meio ambiente. E, dessa forma, coube a agência a responsabilidade da emissão das demonstrações financeiras.

Você trabalha nessa agência como contador, sendo-lhe imputada a responsabilidade direta da elaboração das demonstrações financeiras da companhia. Merece destacar que todas as tarefas, registros contábeis e produção de informações, inclusive àquelas evidenciadas nas notas explicativas não sofrem nenhum tipo de fisscalização ou análise.

Sendo assim, você como contador a serviço do órgão acima descrito é responsável pela produção das informações contábeis, cabe estimar a probabilidade da realização da contingência acima destacada.

\begin{tabular}{|l|}
\hline ( ) $0 \%$ Nenhuma Probabilidade \\
\hline ( ) Até $10 \%$ \\
\hline ( ) Acima de $10 \%$ até $20 \%$ \\
\hline ( ) Acima de $20 \%$ até $30 \%$ \\
\hline ( ) Acima de $30 \%$ até $40 \%$ \\
\hline ( ) Acima de $40 \%$ até $50 \%$ \\
\hline ( ) Acima de $50 \%$ até $60 \%$ \\
\hline ( ) Acima de $60 \%$ até $70 \%$ \\
\hline ( ) Acima de $70 \%$ até $80 \%$ \\
\hline ( ) Acima de $80 \%$ até $90 \%$ \\
\hline ( ) Acima de $90 \%$ até $100 \%$ \\
\hline
\end{tabular}

Além da contingência acima descrita com possibilidade de perda, a empresa possui uma ação na qual pleiteia a devolução do Imposto de Renda sobre o Lucro Líquido de determinada operação. A empresa em questão é beneficiária dessa compensação e por esse motivo fez o pedido de restituição dos valores recolhidos. O fisco federal interpôs recurso não concordando com a restituição. No momento atual, o processo está em pendência de julgamento. No entanto, pelas informações publicadas relacionadas a essa reivindicação, existe uma chance do Supremo Tribunal Federal julgar a inconstitucionalidade da ação. Só assim se confirmaria a realização do crédito tributário.

A administração da empresa através de suas análises avalia regularmente suas contingências.

Em função das especificidades da empresa em questão e pela possibilidade da mesma usufruir de benefícios fiscais viu-se obrigada a se reportar às exigências de um órgão do governo. Para tanto, coube a esse órgão a responsabilidade da emissão das demonstrações financeiras.

Você trabalha nesse órgão governamental como contador, o qual lhe incumbiu a responsabilidade na elaboração das demonstrações financeiras da companhia, inclusive àquelas evidenciadas nas notas explicativas. Todas as tarefas e registros contábeis, não sofrem nenhum tipo de fiscalização ou análise.

Sendo assim, você sendo o contador responsável pela produção das informações contábeis, cabe estimar a estimativa do desfecho do evento acima.

( ) $0 \%$ Nenhuma Probabilidade 


\begin{tabular}{|l|}
\hline ( ) Até $10 \%$ \\
\hline ( ) Acima de $10 \%$ até $20 \%$ \\
\hline ( ) Acima de $20 \%$ até $30 \%$ \\
\hline ( ) Acima de $30 \%$ até $40 \%$ \\
\hline ( ) Acima de $40 \%$ até $50 \%$ \\
\hline ( ) Acima de $50 \%$ até $60 \%$ \\
\hline ( ) Acima de $60 \%$ até $70 \%$ \\
\hline ( ) Acima de $70 \%$ até $80 \%$ \\
\hline ( ) Acima de $80 \%$ até $90 \%$ \\
\hline ( ) Acima de $90 \%$ até $100 \%$ \\
\hline
\end{tabular}

Grupo Controle: C

Variável de Controle: Forma de Contratação - CONTRATADO PELA EMPRESA

Outras Variáveis são mantidas inalteradas

\begin{tabular}{|l|l|}
\hline Quanto à fonte adicional de informação & Advindo da Administração \\
\hline Quanto à existência de fiscalização da tarefa & Sem Fiscalização \\
\hline
\end{tabular}

A empresa Moura tem como atividade preponderante àquelas relacionadas ao transporte de dejetos e está sujeita às exigências associadas com a proteção ao meio ambiente, bem como, a remediação de locais contaminados.

A administração da empresa estima regularmente as contingências, obrigações e compromissos para a remediação de locais contaminados. Nesse contexto, foi verificado no período corrente que os dejetos lançados no terreno atingem o limite imposto pela legislação. Acima desse, a lei obriga o uso de novas tecnologias para a recuperação de locais que sofreram degradação, o que demandaria para a empresa novos investimentos.

Com base em informações levantadas pela própria administração, a lei que trata desses limites está em discussão. A proposta da lei é que haja um aumento desse limite atual. Há fortes indícios que essa mudança esteja bem próxima de acontecer. No entanto, existe uma forte pressão por parte dos ambientalistas, os quais questionam os limites atuais, propondo inclusive uma diminuição dos mesmos. Além dessa discussão, os órgãos de proteção ao meio ambiente também entraram com um pedido de revisão dos limites atuais contrapondo as duas partes acima destacadas. Atualmente, o impasse encontra-se em discussão e depende do sistema judicial. O desfecho refere-se à alteração do limite de dejetos atualmente lançados ao solo; se aumenta ou diminui.

Você foi contratado pela empresa acima para assumir o cargo de contador, sendo dessa forma, o responsável direto pela produção de informações e elaboração das demonstrações financeiras. Merece destacar que todas as tarefas, registros contábeis e produção de informações, inclusive àquelas evidenciadas nas notas explicativas não sofrem nenhum tipo de fiscalização ou análise.

Sendo assim, você como contador responsável pela produção das informações contábeis, cabe estimar a probabilidade da realização da contingência acima destacada.

\begin{tabular}{|l|}
\hline ( ) $0 \%$ Nenhuma Probabilidade \\
\hline ( ) Até $10 \%$ \\
\hline ( ) Acima de $10 \%$ até $20 \%$ \\
\hline ( ) Acima de $20 \%$ até $30 \%$ \\
\hline
\end{tabular}




\begin{tabular}{|l|}
\hline ( ) Acima de $30 \%$ até $40 \%$ \\
\hline ( ) Acima de $40 \%$ até $50 \%$ \\
\hline ( ) Acima de $50 \%$ até $60 \%$ \\
\hline ( ) Acima de $60 \%$ até $70 \%$ \\
\hline ( ) Acima de $70 \%$ até $80 \%$ \\
\hline ( ) Acima de $80 \%$ até $90 \%$ \\
\hline ( ) Acima de $90 \%$ até $100 \%$ \\
\hline
\end{tabular}

Além da contingência acima descrita com possibilidade de perda, a empresa possui uma ação na qual pleiteia a devolução do Imposto de Renda sobre o Lucro Líquido de determinada operação. A empresa em questão é beneficiária dessa compensação e por esse motivo fez o pedido de restituição dos valores recolhidos. $\mathrm{O}$ fisco federal interpôs recurso não concordando com a restituição. No momento atual, o processo está em pendência de julgamento. No entanto, pelas informações publicadas relacionadas a essa reivindicação, existe uma chance do Supremo Tribunal Federal julgar a inconstitucionalidade da ação. Só assim se confirmaria a realização do crédito tributário.

A administração da empresa através de suas análises avalia regularmente suas contingências.

Você foi contratado pela empresa acima para assumir o cargo de contador, sendo dessa forma, o responsável direto pela produção de informações e elaboração das demonstrações financeiras. Merece destacar que todas as tarefas e registros contábeis, inclusive àquelas relacionadas ao cálculo de estimativas não sofrem nenhum tipo de fiscalização ou análise.

Sendo assim, você sendo o contador responsável pela produção das informações contábeis, cabe estimar a estimativa do desfecho do evento acima.

\begin{tabular}{|l|}
\hline ( ) $0 \%$ Nenhuma Probabilidade \\
\hline ( ) Até $10 \%$ \\
\hline ( ) Acima de $10 \%$ até $20 \%$ \\
\hline ( ) Acima de $20 \%$ até $30 \%$ \\
\hline ( ) Acima de $30 \%$ até $40 \%$ \\
\hline ( ) Acima de $40 \%$ até $50 \%$ \\
\hline ( ) Acima de $50 \%$ até $60 \%$ \\
\hline ( ) Acima de $60 \%$ até $70 \%$ \\
\hline ( ) Acima de $70 \%$ até $80 \%$ \\
\hline ( ) Acima de $80 \%$ até $90 \%$ \\
\hline ( ) Acima de $90 \%$ até $100 \%$ \\
\hline
\end{tabular}

\section{Encontro}

\section{Grupo Experimental A:}

Variável de Controle: Fonte Adicional de Informação - Auditoria

Outras Variáveis são mantidas inalteradas

\begin{tabular}{|l|l|}
\hline Forma de Contratação & Contratado pela empresa \\
\hline Quanto à existência de fiscalização da tarefa & Sem Fiscalização \\
\hline
\end{tabular}

A Companhia Metalão fabrica peças para motores as quais são vendidas para as montadoras de automóveis. Os principais produtos fabricados pela companhia são os pistões e anéis de pistão. 
A companhia oferece uma garantia contratual aos seus clientes. No último exercício foi constatado um número elevado de solicitação de substituição de determinada peça. Esses clientes realizaram as revisões fora da rede autorizada. A empresa entende que não existe a obrigatoriedade por parte dela de realizar a substituição da peça em virtude da perda de garantia.

As leis que defendem o consumidor estabelecem uma cobertura mínima. Apesar da substituição não ter sido realizada na autorizada estava dentro do período de garantia. A discussão judicial em primeira instância julga a ação favorável aos clientes, contudo, em segunda instância favorece a companhia.

A administração da empresa quando avalia a contingência acima faz uso das análises e dos pareceres realizados pela equipe de auditores.

Você foi contratado pela empresa acima para assumir o cargo de contador, sendo o responsável direto pela produção de informações e elaboração das demonstrações financeiras. Merece destacar que todas as tarefas, registros contábeis e produção de informações, inclusive àquelas evidenciadas nas notas explicativas não sofrem nenhum tipo de fisscalização ou análise.

Sendo assim, você como contador responsável pela produção das informações contábeis, cabe estimar a probabilidade de ocorrência da contingência acima descrita:

\begin{tabular}{|l|}
\hline ( ) $0 \%$ Nenhuma Probabilidade \\
\hline ( ) Até $10 \%$ \\
\hline ( ) Acima de $10 \%$ até $20 \%$ \\
\hline ( ) Acima de $20 \%$ até $30 \%$ \\
\hline ( ) Acima de $30 \%$ até $40 \%$ \\
\hline ( ) Acima de $40 \%$ até $50 \%$ \\
\hline ( ) Acima de $50 \%$ até $60 \%$ \\
\hline ( ) Acima de $60 \%$ até $70 \%$ \\
\hline ( ) Acima de $70 \%$ até $80 \%$ \\
\hline ( ) Acima de $80 \%$ até $90 \%$ \\
\hline ( ) Acima de $90 \%$ até $100 \%$ \\
\hline
\end{tabular}

Existe também por parte da companhia uma discussão judicial tratando da legalidade do PIS (Programa de Integração Social) sobre a Receita Operacional Bruta, na qual pleiteia uma compensação de valores já recolhidos. Embora o desfecho judicial de primeira instância tenha sido favorável à companhia, as incertezas quanto à contingência ainda permanecem pelo fato do processo encontrar-se em instância superior. Experiências de ações semelhantes relacionadas às outras companhias evidenciam indeferimentos em alguns pedidos de compensação. A empresa defende que o crédito acima solicitado está de acordo com os termos da lei, sendo assim passível de recuperação.

A administração, na avaliação da contingência acima é assessorada pelos pareces e análises realizados pelos auditores da companhia.

Você foi contratado pela empresa acima para assumir o cargo de contador, sendo dessa forma, o responsável direto pela produção de informações e elaboração das demonstrações financeiras. Merece destacar que todas as tarefas e registros contábeis, inclusive àquelas evidenciadas nas notas explicativas não sofrem nenhum tipo de fisscalização ou análise.

Sendo assim, você sendo o contador responsável pela produção das informações contábeis, cabe estimar a estimativa do desfecho do evento acima.

( ) $0 \%$ Nenhuma Probabilidade 


\begin{tabular}{|l|}
\hline ( ) Até $10 \%$ \\
\hline ( ) Acima de $10 \%$ até $20 \%$ \\
\hline ( ) Acima de $20 \%$ até $30 \%$ \\
\hline ( ) Acima de $30 \%$ até $40 \%$ \\
\hline ( ) Acima de $40 \%$ até $50 \%$ \\
\hline ( ) Acima de $50 \%$ até $60 \%$ \\
\hline ( ) Acima de $60 \%$ até $70 \%$ \\
\hline ( ) Acima de $70 \%$ até $80 \%$ \\
\hline ( ) Acima de $80 \%$ até $90 \%$ \\
\hline ( ) Acima de $90 \%$ até $100 \%$ \\
\hline
\end{tabular}

\section{Grupo Experimental B:}

Variável de Controle: Fonte Adicional de Informação - Área Jurídica

Outras Variáveis são mantidas inalteradas

\begin{tabular}{|l|l|}
\hline Forma de Contratação & Contratado pela empresa \\
\hline Quanto à existência de fiscalização da tarefa & Sem Fiscalização \\
\hline
\end{tabular}

A Companhia Metalão fabrica peças para motores as quais são vendidas para as montadoras de automóveis. Os principais produtos fabricados pela companhia são os pistões e anéis de pistão.

A companhia oferece uma garantia contratual aos seus clientes. No último exercício foi constatado um número elevado de solicitação de substituição de determinada peça. Esses clientes realizaram as revisões fora da rede autorizada. A empresa entende que não existe a obrigatoriedade por parte dela de realizar a substituição da peça em virtude da perda de garantia.

As leis que defendem o consumidor estabelecem uma cobertura mínima. Apesar da substituição não ter sido realizada na autorizada estava dentro do período de garantia. A discussão judicial em primeira instância julga a ação favorável aos clientes, contudo, em segunda instância favorece a companhia.

A administração da empresa quando avalia a contingência acima faz uso do parecer emitido pela equipe jurídica. Esses tomam como base os desfechos jurídicos de ações semelhantes.

Você foi contratado pela empresa acima para assumir o cargo de contador, sendo dessa forma, o responsável direto pela produção de informações e elaboração das demonstrações financeiras. Merece destacar que todas as tarefas, registros contábeis e produção de informações, inclusive àquelas evidenciadas nas notas explicativas não sofrem nenhum tipo de fiscalização ou análise.

Sendo assim, você como contador responsável pela produção das informações contábeis, cabe estimar a probabilidade de ocorrência da contingência acima descrita:

\begin{tabular}{|l|}
\hline ( ) $0 \%$ Nenhuma Probabilidade \\
\hline ( ) Até $10 \%$ \\
\hline ( ) Acima de $10 \%$ até $20 \%$ \\
\hline ( ) Acima de $20 \%$ até $30 \%$ \\
\hline ( ) Acima de $30 \%$ até $40 \%$ \\
\hline ( ) Acima de $40 \%$ até $50 \%$ \\
\hline ( ) Acima de $50 \%$ até $60 \%$ \\
\hline ( ) Acima de $60 \%$ até $70 \%$ \\
\hline
\end{tabular}




\begin{tabular}{|l|}
\hline ( ) Acima de $70 \%$ até $80 \%$ \\
\hline ( ) Acima de $80 \%$ até $90 \%$ \\
\hline ( ) Acima de $90 \%$ até $100 \%$ \\
\hline
\end{tabular}

Existe também por parte da companhia uma discussão judicial tratando da legalidade do PIS (Programa de Integração Social) sobre a Receita Operacional Bruta, na qual pleiteia uma compensação de valores já recolhidos. Embora o desfecho judicial de primeira instância tenha sido favorável à companhia, as incertezas quanto à contingência ainda permanecem pelo fato do processo encontrar-se em instância superior. Experiências de ações semelhantes relacionadas às outras companhias evidenciam indeferimentos em alguns pedidos de compensação. A empresa defende que o crédito acima solicitado está de acordo com os termos da lei, sendo assim passível de recuperação.

A administração da empresa quando avalia a contingência acima, faz uso do parecer realizado pela equipe jurídica. Esses elaboram análises com base nos desfechos jurídicos de ações semelhantes.

Você foi contratado pela empresa acima para assumir o cargo de contador, sendo dessa forma, o responsável direto pela produção de informações e elaboração das demonstrações financeiras. Merece destacar que todas as tarefas e registros contábeis, inclusive àquelas evidenciadas nas notas explicativas não sofrem nenhum tipo de fisscalização ou análise.

Sendo assim, você sendo o contador responsável pela produção das informações contábeis, cabe estimar a estimativa do desfecho do evento acima.

\begin{tabular}{|l|}
\hline ( ) $0 \%$ Nenhuma Probabilidade \\
\hline ( ) Até $10 \%$ \\
\hline ( ) Acima de $10 \%$ até $20 \%$ \\
\hline ( ) Acima de $20 \%$ até $30 \%$ \\
\hline ( ) Acima de $30 \%$ até $40 \%$ \\
\hline ( ) Acima de $40 \%$ até $50 \%$ \\
\hline ( ) Acima de $50 \%$ até $60 \%$ \\
\hline ( ) Acima de $60 \%$ até $70 \%$ \\
\hline ( ) Acima de $70 \%$ até $80 \%$ \\
\hline ( ) Acima de $80 \%$ até $90 \%$ \\
\hline ( ) Acima de $90 \%$ até $100 \%$ \\
\hline
\end{tabular}

Grupo Controle: C

Variável de Controle: Fonte Adicional de Informação - Advindo da administração

Outras Variáveis são mantidas inalteradas

\begin{tabular}{|l|l|}
\hline Forma de Contratação & Contratado pela empresa \\
\hline Quanto à existência de fiscalização da tarefa & Sem Fiscalização \\
\hline
\end{tabular}

A Companhia Metalão fabrica peças para motores as quais são vendidas para as montadoras de automóveis. Os principais produtos fabricados pela companhia são os pistões e anéis de pistão.

A companhia oferece uma garantia contratual aos seus clientes. No último exercício foi constatado um número elevado de solicitação de substituição de determinada peça. Esses clientes realizaram as revisões fora da rede autorizada. A empresa entende que não existe a obrigatoriedade por parte dela de realizar a substituição da peça em virtude da perda de garantia. 
As leis que defendem o consumidor estabelecem uma cobertura mínima. Apesar da substituição não ter sido realizada na autorizada estava dentro do período de garantia. A discussão judicial em primeira instância julga a ação favorável aos clientes, contudo, em segunda instância favorece a companhia.

A administração da empresa com base nas suas análises avalia a contingência relacionada com a cobertura de garantia das peças defeituosas.

Você foi contratado pela empresa acima para assumir o cargo de contador, sendo dessa forma, o responsável direto pela produção de informações e elaboração das demonstrações financeiras. Merece destacar que todas as tarefas, registros contábeis e produção de informações, inclusive àquelas evidenciadas nas notas explicativas não sofrem nenhum tipo de fiscalização ou análise.

Sendo assim, você como contador responsável pela produção das informações contábeis, cabe estimar a probabilidade de ocorrência da contingência acima descrita:

\begin{tabular}{|l|}
\hline ( ) $0 \%$ Nenhuma Probabilidade \\
\hline ( ) Até $10 \%$ \\
\hline ( ) Acima de $10 \%$ até $20 \%$ \\
\hline ( ) Acima de $20 \%$ até $30 \%$ \\
\hline ( ) Acima de $30 \%$ até $40 \%$ \\
\hline ( ) Acima de $40 \%$ até $50 \%$ \\
\hline ( ) Acima de $50 \%$ até $60 \%$ \\
\hline ( ) Acima de $60 \%$ até $70 \%$ \\
\hline ( ) Acima de $70 \%$ até $80 \%$ \\
\hline ( ) Acima de $80 \%$ até $90 \%$ \\
\hline ( ) Acima de $90 \%$ até $100 \%$ \\
\hline
\end{tabular}

Existe também por parte da companhia uma discussão judicial tratando da legalidade do PIS (Programa de Integração Social) sobre a Receita Operacional Bruta, na qual pleiteia uma compensação de valores já recolhidos. Embora o desfecho judicial de primeira instância tenha sido favorável à companhia, as incertezas quanto à contingência ainda permanecem pelo fato do processo encontrar-se em instância superior. Experiências de ações semelhantes relacionadas às outras companhias evidenciam indeferimentos em alguns pedidos de compensação. A empresa defende que o crédito acima solicitado está de acordo com os termos da lei, sendo assim passível de recuperação.

A administração da empresa com base nas suas análises avalia a contingência relacionada à legalidade do imposto acima.

Você foi contratado pela empresa acima para assumir o cargo de contador, sendo dessa forma, o responsável direto pela produção de informações e elaboração das demonstrações financeiras. Merece destacar que todas as tarefas e registros contábeis, inclusive àquelas evidenciadas nas notas explicativas não sofrem nenhum tipo de fisscalização ou análise.

Sendo assim, você sendo o contador responsável pela produção das informações contábeis, cabe estimar a estimativa do desfecho do evento acima.

\begin{tabular}{|l|}
\hline ( ) $0 \%$ Nenhuma Probabilidade \\
\hline ( ) Até $10 \%$ \\
\hline ( ) Acima de $10 \%$ até $20 \%$ \\
\hline ( ) Acima de $20 \%$ até $30 \%$ \\
\hline ( ) Acima de $30 \%$ até $40 \%$ \\
\hline ( ) Acima de $40 \%$ até $50 \%$ \\
\hline
\end{tabular}




\begin{tabular}{|l|}
\hline ( ) Acima de $50 \%$ até $60 \%$ \\
\hline ( ) Acima de $60 \%$ até $70 \%$ \\
\hline ( ) Acima de $70 \%$ até $80 \%$ \\
\hline ( ) Acima de $80 \%$ até $90 \%$ \\
\hline ( ) Acima de $90 \%$ até $100 \%$ \\
\hline
\end{tabular}

\section{Encontro}

\section{Grupo Experimental A:}

Variável de Controle: Existência de Fiscalização de Tarefas - FISCALIZADO PELOS GERENTES SUPERIORES

Outras Variáveis são mantidas inalteradas

\begin{tabular}{|l|l|}
\hline Quanto à Forma de Contratação & Contratado pela empresa \\
\hline Quanto à fonte adicional de informação & Advindo da Administração \\
\hline
\end{tabular}

A Companhia é uma indústria de papel e tem como atividade principal a fabricação de embalagem de papelão.

Estão em andamento duas reclamatórias trabalhistas movidas contra a entidade. Em primeira instância o resultado foi favorável à empresa. Mas a jurisprudência em instância superior contrapõe a decisão em virtude de algumas informações relacionadas à periculosidade vivenciada pelos funcionários. Estabelece-se um impasse no qual os riscos de perda por parte da empresa dependem do desfecho judicial.

A administração faz uso apenas de suas análises para julgar a probabilidade da ocorrência da contingência anteriormente exposta.

Você foi contratado pela empresa acima para assumir o cargo de contador. Pela estrutura organizacional da empresa o seu cargo encontra-se hierarquicamente em níveis inferiores e em função disso, todas as tarefas e registros contábeis realizados por você, inclusive àquelas evidenciadas nas notas explicativas são físcalizados pelos seus gerentes superiores.

Você sendo o contador responsável pela produção das informações contábeis necessita estimar a probabilidade da realização da contingência acima destacada.

\begin{tabular}{|l|}
\hline () $0 \%$ Nenhuma Probabilidade \\
\hline () Até $10 \%$ \\
\hline () Acima de $10 \%$ até $20 \%$ \\
\hline () Acima de $20 \%$ até $30 \%$ \\
\hline () Acima de $30 \%$ até $40 \%$ \\
\hline () Acima de $40 \%$ até $50 \%$ \\
\hline ) Acima de $50 \%$ até $60 \%$ \\
\hline () Acima de $60 \%$ até $70 \%$ \\
\hline () Acima de $70 \%$ até $80 \%$ \\
\hline () Acima de $80 \%$ até $90 \%$ \\
\hline () Acima de $90 \%$ até $100 \%$ \\
\hline
\end{tabular}


A empresa reivindica na justiça valores recolhidos ao INSS (Instituto Nacional de Seguridade Social). Ela defende a não incidência do tributo sobre a participação nos lucros e resultados. Em um primeiro momento a justiça considerou favorável e pertinente o litigio. Existe atualmente uma jurisprudência aplicada para casos semelhantes na qual se verifica um entendimento contrario. A contingência acima depende do desfecho judicial de instâncias superiores.

A administração faz uso apenas de suas análises para julgar a probabilidade da ocorrência da contingência anteriormente exposta.

Você foi contratado pela empresa acima para assumir o cargo de contador. Pela estrutura organizacional da empresa o seu cargo encontra-se hierarquicamente em níveis inferiores e em função disso, todas as tarefas e registros contábeis realizados por você, inclusive àquelas evidenciadas nas notas explicativas são fiscalizados pelos seus gerentes superiores.

Você sendo o contador responsável pela produção das informações contábeis necessita estimar a probabilidade da realização da contingência acima destacada.

\begin{tabular}{|l|}
\hline ( ) $0 \%$ Nenhuma Probabilidade \\
\hline ( ) Até $10 \%$ \\
\hline ( ) Acima de $10 \%$ até $20 \%$ \\
\hline ( ) Acima de $20 \%$ até $30 \%$ \\
\hline ( ) Acima de $30 \%$ até $40 \%$ \\
\hline ( ) Acima de $40 \%$ até $50 \%$ \\
\hline ( ) Acima de $50 \%$ até $60 \%$ \\
\hline ( ) Acima de $60 \%$ até $70 \%$ \\
\hline ( ) Acima de $70 \%$ até $80 \%$ \\
\hline ( ) Acima de $80 \%$ até $90 \%$ \\
\hline ( ) Acima de $90 \%$ até $100 \%$ \\
\hline
\end{tabular}

Grupo Experimental B:

Variável de Controle: Existência de Fiscalização de Tarefas - FISCALIZADO POR PROFISSIONAIS EXTERNOS

Outras Variáveis são mantidas inalteradas

\begin{tabular}{|l|l|}
\hline Quanto à Forma de Contratação & Contratado pela empresa \\
\hline Quanto à fonte adicional de informação & Advindo da Administração \\
\hline
\end{tabular}

A Companhia é uma indústria de papel e tem como atividade principal a fabricação de embalagem de papelão.

Estão em andamento duas reclamatórias trabalhistas movidas contra a entidade. Em primeira instância o resultado foi favorável à empresa. Mas a jurisprudência em instância superior contrapõe a decisão em virtude de algumas informações relacionadas à periculosidade vivenciada pelos funcionários. Estabelece-se um impasse no qual os riscos de perda por parte da empresa dependem do desfecho judicial.

A administração faz uso apenas de suas análises para julgar a probabilidade da ocorrência da contingência anteriormente exposta. 
Você foi contratado pela empresa acima para assumir o cargo de contador. Os relatórios e as informações evidenciadas nas notas explicativas produzidos por você são fiscalizados por profissionais externos contratados pela companhia.

Você sendo o contador responsável pela produção das informações contábeis necessita estimar a probabilidade da realização da contingência acima destacada.

\begin{tabular}{|l|}
\hline ( ) $0 \%$ Nenhuma Probabilidade \\
\hline ( ) Até $10 \%$ \\
\hline ( ) Acima de $10 \%$ até $20 \%$ \\
\hline ( ) Acima de $20 \%$ até $30 \%$ \\
\hline ( ) Acima de $30 \%$ até $40 \%$ \\
\hline ( ) Acima de $40 \%$ até $50 \%$ \\
\hline ( ) Acima de $50 \%$ até $60 \%$ \\
\hline ( ) Acima de $60 \%$ até $70 \%$ \\
\hline ( ) Acima de $70 \%$ até $80 \%$ \\
\hline ( ) Acima de $80 \%$ até $90 \%$ \\
\hline ( ) Acima de $90 \%$ até $100 \%$ \\
\hline
\end{tabular}

A empresa reivindica na justiça valores recolhidos ao INSS (Instituto Nacional de Seguridade Social). Ela defende a não incidência do tributo sobre a participação nos lucros e resultados. Em um primeiro momento a justiça considerou favorável e pertinente o litigio. Existe atualmente uma jurisprudência aplicada para casos semelhantes na qual se verifica um entendimento contrario. A contingência acima depende do desfecho judicial de instâncias superiores.

A administração faz uso apenas de suas análises para julgar a probabilidade da ocorrência da contingência anteriormente exposta.

Você foi contratado pela empresa acima para assumir o cargo de contador. Os relatórios e as informações evidenciadas nas notas explicativas produzidos por você são físcalizados por profissionais externos contratados pela companhia.

Você sendo o contador responsável pela produção das informações contábeis necessita estimar a probabilidade da realização da contingência acima destacada.

\begin{tabular}{|l|}
\hline ( ) $0 \%$ Nenhuma Probabilidade \\
\hline ( ) Até $10 \%$ \\
\hline ( ) Acima de $10 \%$ até $20 \%$ \\
\hline ( ) Acima de $20 \%$ até $30 \%$ \\
\hline ( ) Acima de $30 \%$ até $40 \%$ \\
\hline ( ) Acima de $40 \%$ até $50 \%$ \\
\hline ( ) Acima de $50 \%$ até $60 \%$ \\
\hline ( ) Acima de $60 \%$ até $70 \%$ \\
\hline ( ) Acima de $70 \%$ até $80 \%$ \\
\hline ( ) Acima de $80 \%$ até $90 \%$ \\
\hline ( ) Acima de $90 \%$ até $100 \%$ \\
\hline
\end{tabular}

Grupo Controle: $\mathbf{C}$

Variável de Controle: Existência de Fiscalização de Tarefas - SEM FISCALIZAÇÃO 
Outras Variáveis são mantidas inalteradas

\begin{tabular}{|l|l|}
\hline Quanto à Forma de Contratação & Contratado pela empresa \\
\hline Quanto à fonte adicional de informação & Advindo da Administração \\
\hline
\end{tabular}

A Companhia é uma indústria de papel e tem como atividade principal a fabricação de embalagem de papelão.

Estão em andamento duas reclamatórias trabalhistas movidas contra a entidade. Em primeira instância o resultado foi favorável à empresa. Mas a jurisprudência em instância superior contrapõe a decisão em virtude de algumas informações relacionadas à periculosidade vivenciada pelos funcionários. Estabelece-se um impasse no qual os riscos de perda por parte da empresa dependem do desfecho judicial.

A administração faz uso apenas de suas análises para julgar a probabilidade da ocorrência da contingência anteriormente exposta.

Você foi contratado pela empresa acima para assumir o cargo de contador sendo o responsável direto pela produção de informações e elaboração das demonstrações financeiras. Merece destacar que todas as tarefas e registros contábeis, inclusive àquelas informações evidenciadas nas notas explicativas não sofrem nenhum tipo de fiscalização ou análise.

Você sendo o contador responsável pela produção das informações contábeis necessita estimar a probabilidade da realização da contingência acima destacada.

\begin{tabular}{|l|}
\hline () $0 \%$ Nenhuma Probabilidade \\
\hline () Até $10 \%$ \\
\hline () Acima de $10 \%$ até $20 \%$ \\
\hline () Acima de $20 \%$ até $30 \%$ \\
\hline () Acima de $30 \%$ até $40 \%$ \\
\hline () Acima de $40 \%$ até $50 \%$ \\
\hline ) Acima de $50 \%$ até $60 \%$ \\
\hline () Acima de $60 \%$ até $70 \%$ \\
\hline () Acima de $70 \%$ até $80 \%$ \\
\hline () Acima de $80 \%$ até $90 \%$ \\
\hline () Acima de $90 \%$ até $100 \%$ \\
\hline
\end{tabular}

A empresa reivindica na justiça valores recolhidos ao INSS (Instituto Nacional de Seguridade Social). Ela defende a não incidência do tributo sobre a participação nos lucros e resultados. Em um primeiro momento a justiça considerou favorável e pertinente o litigio. Existe atualmente uma jurisprudência aplicada para casos semelhantes na qual se verifica um entendimento contrario. A contingência acima depende do desfecho judicial de instâncias superiores.

A administração faz uso apenas de suas análises para julgar a probabilidade da ocorrência da contingência anteriormente exposta.

Você foi contratado pela empresa acima para assumir o cargo de contador sendo o responsável direto pela produção de informações e elaboração das demonstrações financeiras. Merece destacar que todas as tarefas e registros contábeis, inclusive àquelas evidenciadas nas notas explicativas não sofrem nenhum tipo de fiscalização ou análise. 
Você, sendo o contador responsável pela produção das informações contábeis necessita estimar a probabilidade da realização da contingência acima destacada.

\begin{tabular}{|l|}
\hline () $0 \%$ Nenhuma Probabilidade \\
\hline () Até $10 \%$ \\
\hline () Acima de $10 \%$ até $20 \%$ \\
\hline ) Acima de $20 \%$ até $30 \%$ \\
\hline () Acima de $30 \%$ até $40 \%$ \\
\hline () Acima de $40 \%$ até $50 \%$ \\
\hline ) Acima de $50 \%$ até $60 \%$ \\
\hline ) Acima de $60 \%$ até $70 \%$ \\
\hline () Acima de $70 \%$ até $80 \%$ \\
\hline () Acima de $80 \%$ até $90 \%$ \\
\hline () Acima de $90 \%$ até $100 \%$ \\
\hline
\end{tabular}


APÊNDICE B - Dados Descritivos

Dados da Amostra

\begin{tabular}{lcc}
\hline & Amostra Total & Amostra Usada \\
\hline $\mathrm{N}$ & 128 & 87 \\
Média da Idade & 38,84 & 39,41 \\
\% Mulheres & $47 \%$ & $52 \%$ \\
Média Experiência & 12,30 & 11,90 \\
Média EO & $-0,084$ & $-0,100$ \\
\hline
\end{tabular}

$\%$ de Mulheres

Hipótese nula: as proporções das populações são iguais

\begin{tabular}{lcc}
\hline & Amostra 1 & Amostra 2 \\
\hline $\mathrm{N}$ & 128 & 87 \\
Proporção & 0,47 & 0,52 \\
\hline
\end{tabular}

Estatística de teste: $\mathrm{z}=(0,47-0,52) / 0,0694611=-0,719827$ p-valor bicaudal $=0,4716$

(unicaudal $=0,2358$ )

\section{Média da Idade}

Hipótese nula: Diferença de médias $=0$

\begin{tabular}{lcc}
\hline & Amostra 1 & Amostra 2 \\
\hline $\mathrm{N}$ & 128 & 87 \\
Média & 38,84 & 39,41 \\
Desvio & 10,5565 & 10,9731 \\
Erro padrão da Média & 0,933072 & 1,176440 \\
Intervalo de confiança & 36,9936 a 40,6864 & 37,0713 a 41,7487 \\
de 95\% para a média: & & \\
\hline
\end{tabular}

Estatística de teste: $\mathrm{t}(213)=(38,84-39,41) / 1,49045=-0,382434$ p-valor bicaudal $=0,7025$

(unicaudal $=0,3513$ )

Média Experiência

Hipótese nula: Diferença de médias $=0$

\begin{tabular}{lcc}
\hline & Amostra 1 & Amostra 2 \\
\hline $\mathrm{N}$ & 128 & 87 \\
Média & 12,30 & 11,90 \\
Desvio & 9,8263 & 10,3562 \\
Erro padrão da Média & 0,868530 & 1,110300 \\
Intervalo de confiança & 10,5813 a 14,0187 & 9,69279 a 14,1072 \\
de 95\% para a média: & & \\
\hline
\end{tabular}

Estatística de teste: $\mathrm{t}(213)=(12,3-11,9) / 1,39555=0,286626$

p-valor bicaudal $=0,7747$

(unicaudal $=0,3873$ ) 
Média EO

Hipótese nula: Diferença de médias $=0$

\begin{tabular}{lcc}
\hline & Amostra 1 & Amostra 2 \\
\hline $\mathrm{N}$ & 128 & 87 \\
Média & $-0,084$ & $-0,10$ \\
Desvio & 1,3258 & 1,6010 \\
Erro padrão da Média & 0,117186 & 0,171647 \\
Intervalo de confiança & $-0,315889$ a 0,147889 & $-0,441223$ a 0,241223 \\
de 95\% para a média: &
\end{tabular}

Estatística de teste: $\mathrm{t}(213)=(-0,084--0,1) / 0,200538=0,0797852$ p-valor bicaudal $=0,9365$

(unicaudal $=0,4682$ )

Estatística Descritiva das variáveis

\begin{tabular}{lcccccrc}
\hline Variável & Idade & Experiência & EO & FMCon & FMExp & Passivo & Ativo \\
\hline Média & 39,41 & 11,90 & $-0,10$ & 0,10 & $-0,07$ & 19,83 & 19,67 \\
Mediana & 38,00 & 9,00 & $-0,60$ & $-0,20$ & - & 20,00 & 40,00 \\
Mínimo & 23,00 & - & $-4,10$ & $-1,90$ & $-4,50$ & 6,00 & 12,00 \\
Máximo & 78,00 & 52,00 & 4,10 & 3,50 & 3,60 & 33,00 & 63,00 \\
Desvio & 10,97 & 10,36 & 1,60 & 1,09 & 1,45 & 6,16 & 10,69 \\
Assimetria & 0,89 & 1,47 & $-0,05$ & 0,67 & $-0,31$ & $-0,08$ & $-0,13$ \\
Curtose & 0,77 & 2,34 & $-0,02$ & 0,36 & 1,08 & $-0,38$ & $-0,41$ \\
\hline
\end{tabular}

\begin{tabular}{cccccccc}
\hline Variável & Média & Mediana & Mínimo & Máximo & Desvio & Assimetria & Curtose \\
\hline Idade & 39,47 & 38,00 & 23,00 & 78,00 & 10,97 & 0,77 & 0,44 \\
Experiência & 11,94 & 8,00 & 0,00 & 52,00 & 10,92 & 1,52 & 1,96 \\
EO & $-0,03$ & 0,80 & $-4,10$ & 4,10 & 1,83 & $-0,09$ & $-0,84$ \\
FMCon & 0,08 & 0,00 & $-1,90$ & 3,50 & 1,06 & 0,52 & 0,37 \\
FMExp & $-0,09$ & 0,10 & $-4,50$ & 3,60 & 1,66 & $-0,41$ & 0,44 \\
Passivo & 20,31 & 21,00 & 6,00 & 32,00 & 5,84 & $-0,33$ & $-0,71$ \\
Ativo & 20,39 & 21,00 & 6,00 & 33,00 & 5,49 & $-0,19$ & 0,04 \\
\hline
\end{tabular}




\section{APÊNDICE C - Dados da Análise}

Fator Moderador Controle

Medida de fidedignidade Alpha de Cronbach para o instrumento aplicado, sua correlação com o item total e quadrado da correlação múltipla

\begin{tabular}{|c|c|c|c|}
\hline Item & $\begin{array}{l}\text { Cor. Com o } \\
\text { item total }\end{array}$ & $\begin{array}{l}\text { Quadrado da } \\
\text { Cor. múltipla }\end{array}$ & $\begin{array}{c}\text { Alpha de Crombach para o } \\
\text { item excluído }\end{array}$ \\
\hline Q1 & 0,252 & 0,312 & 0,841 \\
\hline Q2 & 0,254 & 0,381 & 0,839 \\
\hline Q3 & 0,342 & 0,557 & 0,836 \\
\hline Q4 & 0,318 & 0,465 & 0,837 \\
\hline Q5 & 0,529 & 0,665 & 0,828 \\
\hline Q6 & 0,371 & 0,391 & 0,835 \\
\hline Q7 & 0,268 & 0,542 & 0,840 \\
\hline Q8 & 0,279 & 0,391 & 0,839 \\
\hline Q9 & 0,318 & 0,581 & 0,837 \\
\hline Q10 & 0,392 & 0,456 & 0,834 \\
\hline Q11 & 0,575 & 0,523 & 0,825 \\
\hline Q12 & 0,322 & 0,433 & 0,837 \\
\hline Q13 & 0,462 & 0,600 & 0,831 \\
\hline Q14 & 0,421 & 0,496 & 0,833 \\
\hline Q15 & 0,543 & 0,566 & 0,827 \\
\hline Q16 & 0,584 & 0,491 & 0,825 \\
\hline Q17 & 0,584 & 0,595 & 0,825 \\
\hline Q18 & 0,600 & 0,531 & 0,825 \\
\hline Q19 & 0,449 & 0,561 & 0,831 \\
\hline Q20 & 0,520 & 0,512 & 0,828 \\
\hline Todos & - & - & 0,841 \\
\hline
\end{tabular}

Fator Moderador Experiência

Medida de fidedignidade Alpha de Cronbach para o instrumento aplicado, sua correlação com o item total e quadrado da correlação múltipla

\begin{tabular}{c|c|c|c}
\hline Item & $\begin{array}{c}\text { Cor. Com o } \\
\text { item total }\end{array}$ & $\begin{array}{c}\text { Quadrado da } \\
\text { Cor. múltipla }\end{array}$ & $\begin{array}{c}\text { Alpha de Crombach para o } \\
\text { item excluído }\end{array}$ \\
\hline Q1 & 0,360 & 0,499 & 0,871 \\
\hline
\end{tabular}




\begin{tabular}{c|c|c|c}
\hline Q2 & 0,501 & 0,559 & 0,866 \\
\hline Q3 & 0,433 & 0,444 & 0,869 \\
\hline Q4 & 0,517 & 0,542 & 0,866 \\
\hline Q5 & 0,555 & 0,615 & 0,864 \\
\hline Q6 & 0,418 & 0,459 & 0,870 \\
\hline Q7 & 0,423 & 0,505 & 0,869 \\
\hline Q8 & 0,432 & 0,427 & 0,869 \\
\hline Q9 & 0,204 & 0,215 & 0,878 \\
\hline Q10 & 0,477 & 0,509 & 0,867 \\
\hline Q11 & 0,640 & 0,666 & 0,862 \\
\hline Q12 & 0,404 & 0,480 & 0,870 \\
\hline Q13 & 0,501 & 0,680 & 0,867 \\
\hline Q14 & 0,425 & 0,585 & 0,869 \\
\hline Q15 & 0,620 & 0,657 & 0,862 \\
\hline Q16 & 0,641 & 0,688 & 0,862 \\
\hline Q17 & 0,514 & 0,499 & 0,866 \\
\hline Q18 & 0,616 & 0,721 & 0,862 \\
\hline Q19 & 0,330 & 0,414 & 0,872 \\
\hline Q20 & 0,543 & 0,631 & 0,865 \\
\hline Todos & - & - & 0,877 \\
\hline
\end{tabular}

Excessivamente Otimista

Medida de fidedignidade Alpha de Cronbach para o instrumento aplicado, sua correlação com o item total e quadrado da correlação múltipla

\begin{tabular}{c|c|c|c}
\hline Item & $\begin{array}{c}\text { Cor. Com o } \\
\text { item total }\end{array}$ & $\begin{array}{c}\text { Quadrado da } \\
\text { Cor. múltipla }\end{array}$ & $\begin{array}{c}\text { Alpha de Crombach para o } \\
\text { item excluído }\end{array}$ \\
\hline Q1 & 0,389 & 0,283 & 0,728 \\
\hline Q2 & 0,221 & 0,373 & 0,742 \\
\hline Q3 & 0,253 & 0,305 & 0,739 \\
\hline Q4 & 0,275 & 0,406 & 0,738 \\
\hline Q5 & 0,421 & 0,478 & 0,727 \\
\hline Q6 & 0,296 & 0,376 & 0,736 \\
\hline Q7 & 0,128 & 0,356 & 0,750 \\
\hline Q8 & 0,367 & 0,442 & 0,730 \\
\hline Q9 & 0,167 & 0,379 & 0,745 \\
\hline
\end{tabular}




\begin{tabular}{c|l|l|l}
\hline Q10 & 0,223 & 0,249 & 0,742 \\
\hline Q11 & 0,362 & 0,398 & 0,731 \\
\hline Q12 & 0,297 & 0,365 & 0,736 \\
\hline Q13 & 0,333 & 0,359 & 0,733 \\
\hline Q14 & 0,265 & 0,321 & 0,738 \\
\hline Q15 & 0,440 & 0,406 & 0,725 \\
\hline Q16 & 0,344 & 0,472 & 0,732 \\
\hline Q17 & 0,231 & 0,368 & 0,741 \\
\hline Q18 & 0,551 & 0,520 & 0,715 \\
\hline Q19 & 0,250 & 0,509 & 0,739 \\
\hline Q20 & 0,336 & 0,332 & 0,733 \\
\hline Todos & & & 0,785 \\
\hline
\end{tabular}

Modelo 1: MQO, usando as observações 1-87

Variável dependente: Ativo

$\begin{array}{lccccc} & \text { Coeficiente } & \text { Erro Padrão } & \text { razão-t } & \text { p-valor } & \\ \text { DummyEO } & 20,6195 & 2,34628 & 8,7882 & <0,00001 & * * * \\ \text { Contr } & 3,2531 & 1,59553 & 2,0389 & 0,04461 & * * \\ \text { Experiencia } & 0,919915 & 1,24226 & 0,7405 & 0,46105 & \\ & & & & & \\ \text { Média var. dependente } & 19,66667 & \text { D.P. var. dependente } & 5,798289 \\ \text { Soma resíd. quadrados } & 18514,06 & \text { E.P. da regressão } & 14,84606 \\ \text { R-quadrado } & 0,493335 & \text { R-quadrado ajustado } & 0,481271 \\ \text { F(3,84) } & 27,26331 & \text { P-valor(F) } & 2,08 \mathrm{e}-12 \\ \text { Log da verossimilhança } & -356,6241 & \text { Critério de Akaike } & 719,2481 \\ \text { Critério de Schwarz } & 726,6459 & \text { Critério Hannan-Quinn } & 722,2270\end{array}$

Modelo 2: MQO, usando as observações 1-87

Variável dependente: Ativo

$\begin{array}{lccccc} & \text { Coeficiente } & \text { Erro Padrão } & \text { razão-t } & p \text {-valor } & \\ \text { DummyEO } & 20,15 & 2,25299 & 8,9437 & <0,00001 & * * * \\ \text { Contr } & 3,69225 & 1,47728 & 2,4994 & 0,01436 & * *\end{array}$


Média var. dependente

Soma resíd. quadrados

R-quadrado

$\mathrm{F}(2,85)$

Log da verossimilhança

Critério de Schwarz
19,66667

D.P. var. dependente

5,798289

18634,92

E.P. da regressão

0,490027

R-quadrado ajustado

40,83777

P-valor(F)

$-356,9071$

Critério de Akaike

Critério Hannan-Quinn
14,80656

0,484027

$3,72 \mathrm{e}-13$

717,8142

719,8001

Teste de White para a heteroscedasticidade MQO, usando as observações 1-87

Variável dependente: uhat`2 $^{\wedge}$

coeficiente erro padrão razão-t p-valor

const $34,9777 \quad 7,98987 \quad 4,378 \quad 3,68 e-05 * \star \star$

$\begin{array}{lllll}\text { Dummyeo } & 1,63396 & 10,0414 & 0,1627 & 0,8712\end{array}$

$\begin{array}{lllll}\text { Contr } & -3,65912 & 7,63795 & -0,4791 & 0,6332\end{array}$

$\begin{array}{lllll}\text { Experiencia } & -2,99905 & 5,38395 & -0,5570 & 0,5791\end{array}$

$\begin{array}{lllll}X 2 \_X 3 & 5,28887 & 9,46835 & 0,5586 & 0,5780\end{array}$

$\begin{array}{lllll}X 2 \_X 4 & 10,4418 & 7,75005 & 1,347 & 0,1818\end{array}$

$\begin{array}{lllll}\text { sq_Contr } & -0,975028 & 3,11648 & -0,3129 & 0,7552\end{array}$

$\begin{array}{lllll}X 3 \_X 4 & 9,37382 & 4,97070 & 1,886 & 0,0630\end{array}$

sq_Experienci $\quad-0,534353 \quad 1,70663 \quad-0,3131 \quad 0,7550$

R-quadrado não-ajustado $=0,072633$

Estatística de teste: $\mathrm{TR}^{\wedge} 2=6,319029$,

com $\mathrm{p}$-valor $=\mathrm{P}($ Qui-quadrado $(8)>6,319029)=0,611543$ 


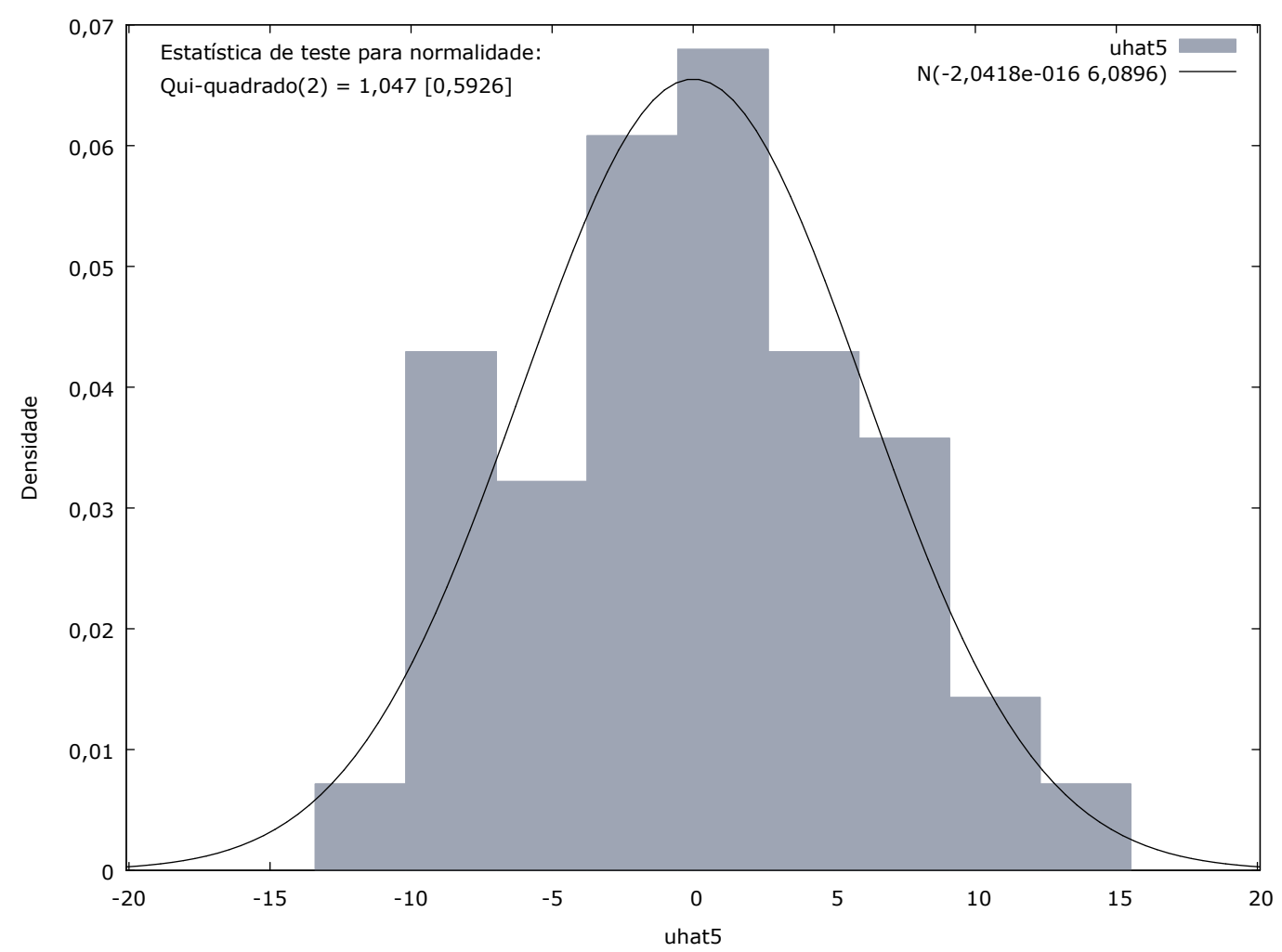

Distribuição de frequência para uhat5, observações 1-87

número de classes $=9$, média $=-2,04179 e-016$, desvio padrão $=6,08965$

\begin{tabular}{|c|c|c|c|c|c|c|c|}
\hline \multicolumn{3}{|c|}{ intervalo } & pt. médio & \multicolumn{2}{|c|}{ frequência } & \multirow{2}{*}{$\begin{array}{l}\text { rel. } \\
2,30 \%\end{array}$} & \multirow[t]{2}{*}{ acum. } \\
\hline & $<$ & $-10,189$ & $-11,795$ & 2 & $2,30 \%$ & & \\
\hline$-10,189$ & - & $-6,9758$ & $-8,5822$ & 12 & $13,79 \%$ & $16,09 \%$ & $\star \star \star \star *$ \\
\hline$-6,9758$ & - & $-3,7631$ & $-5,3695$ & 9 & $10,34 \%$ & $26,44 \%$ & $\star \star \star$ \\
\hline$-3,7631$ & - & $-0,55043$ & $-2,1568$ & 17 & $19,54 \%$ & $45,98 \%$ & 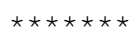 \\
\hline$-0,55043$ & - & 2,6623 & 1,0559 & 19 & $21,84 \%$ & $67,82 \%$ & 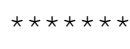 \\
\hline 2,6623 & - & 5,8750 & 4,2686 & 12 & $13,79 \%$ & $81,61 \%$ & $\star \star \star \star ~$ \\
\hline 5,8750 & - & 9,0877 & 7,4813 & 10 & $11,49 \%$ & $93,10 \%$ & $\star \star \star \star ~$ \\
\hline 9,0877 & - & 12,300 & 10,694 & 4 & $4,60 \%$ & $97,70 \%$ & * \\
\hline & $>=$ & 12,300 & 13,907 & 2 & $2,30 \%$ & $100,00 \%$ & \\
\hline
\end{tabular}

Teste para a hipótese nula de distribuição normal:

Qui-quadrado $(2)=1,047 \mathrm{com}$ p-valor 0,59258

Fatores de Inflacionamento da Variância (VIF) 


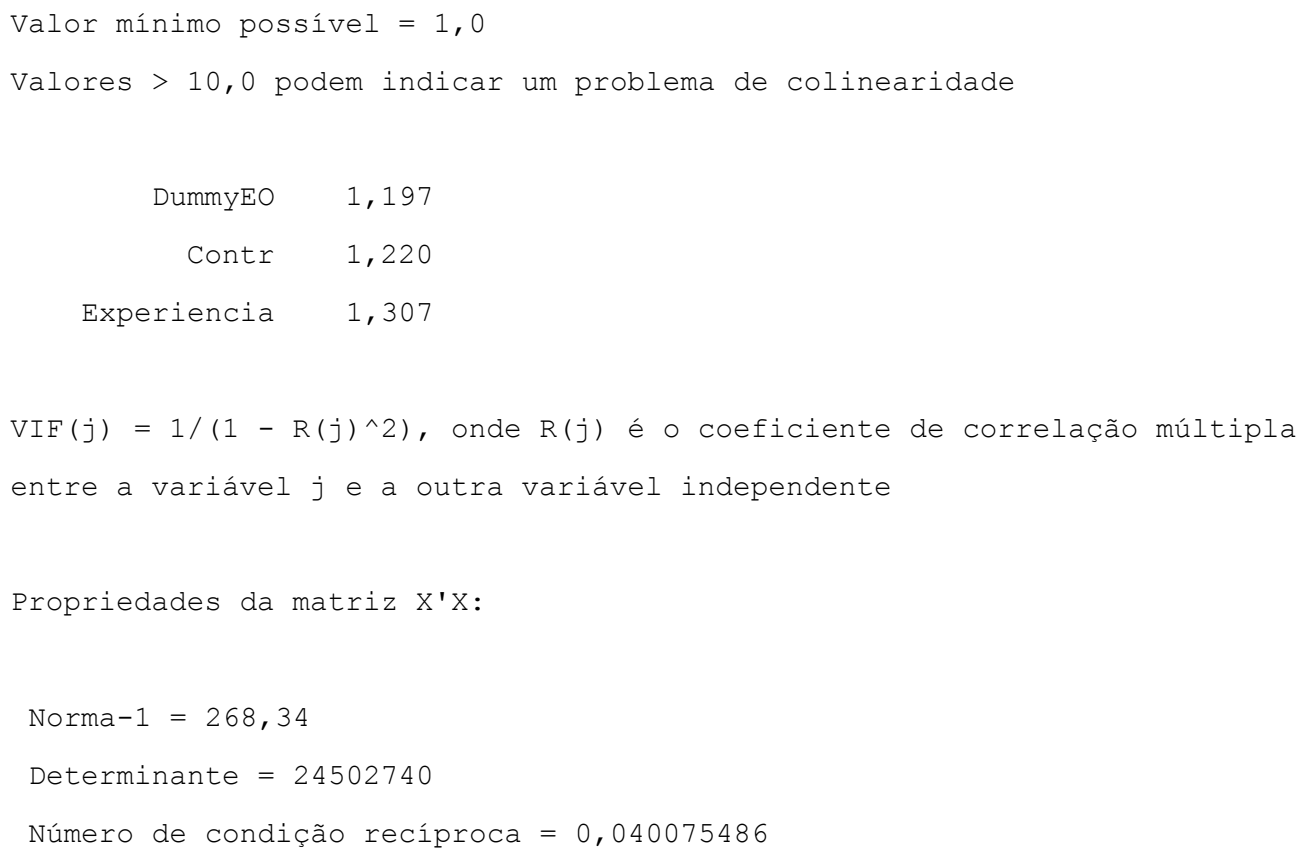

Modelo 3: MQO, usando as observações 1-87

Variável dependente: Passivo

\begin{tabular}{lccccc} 
& Coeficiente & Erro Padrão & razão-t & \multicolumn{2}{c}{$p$-valor } \\
DummyEO & 20,1771 & 2,48245 & 8,1279 & $<0,00001$ & $* * *$ \\
Contr & 2,11758 & 1,68813 & 1,2544 & 0,21318 \\
Experiencia & 1,43735 & 1,31436 & 1,0936 & 0,27727 \\
& & & & \\
Média var. dependente & 19,82759 & D.P. var. dependente & 6,161031 \\
Soma resíd. quadrados & 20725,41 & E.P. da regressão & 15,70768 \\
R-quadrado & 0,446836 & R-quadrado ajustado & 0,433665 \\
F(3, 84) & 22,61786 & P-valor(F) & $7,93 \mathrm{e}-11$ \\
Log da verossimilhança & $-361,5322$ & Critério de Akaike & 729,0644 \\
Critério de Schwarz & 736,4621 & Critério Hannan-Quinn & 732,0432
\end{tabular}

Modelo 4: MQO, usando as observações 1-87

Variável dependente: Passivo

Coeficiente Erro Padrão razão-t p-valor 
DummyEO

Contr

Média var. dependente

Soma resíd. quadrados

R-quadrado

$\mathrm{F}(2,85)$

Log da verossimilhança

Critério de Schwarz
19,4435

2,80375

2,39285

1,56899
8,1257

1,7870

$<0,00001$

$0,07751 *$

MQO, usando as observações 1-87

Variável dependente: uhat^2

\begin{tabular}{|c|c|c|c|c|c|}
\hline & coeficiente & erro padrão & razão-t & p-valor & \\
\hline const & 29,2164 & 6,05742 & 4,823 & $6,86 e-06$ & $\star \star \star$ \\
\hline DummyEO & 1,47519 & 7,61278 & 0,1938 & 0,8469 & \\
\hline Contr & $-11,6449$ & 5,79062 & $-2,011$ & 0,0478 & $\star \star$ \\
\hline Experiencia & $-1,91609$ & 4,08178 & $-0,4694$ & 0,6401 & \\
\hline$x 2+x 3$ & 12,1922 & 7,17832 & 1,698 & 0,0934 & * \\
\hline$x 2+x 4$ & 5,14118 & 5,87561 & 0,8750 & 0,3843 & \\
\hline sq_Contr & 0,644189 & 2,36272 & 0,2726 & 0,7858 & \\
\hline$x 3 x^{4}$ & 10,3929 & 3,76847 & 2,758 & 0,0072 & $\star \star \star$ \\
\hline sq_Experienci & $-0,571105$ & 1,29386 & $-0,4414$ & 0,6601 & \\
\hline
\end{tabular}

$\mathrm{R}$-quadrado não-ajustado $=0,164546$

Estatística de teste: $\mathrm{TR}^{\wedge} 2=14,315503$,

comp-valor $=\mathrm{P}($ Qui-quadrado $(8)>14,315503)=0,073904$ 


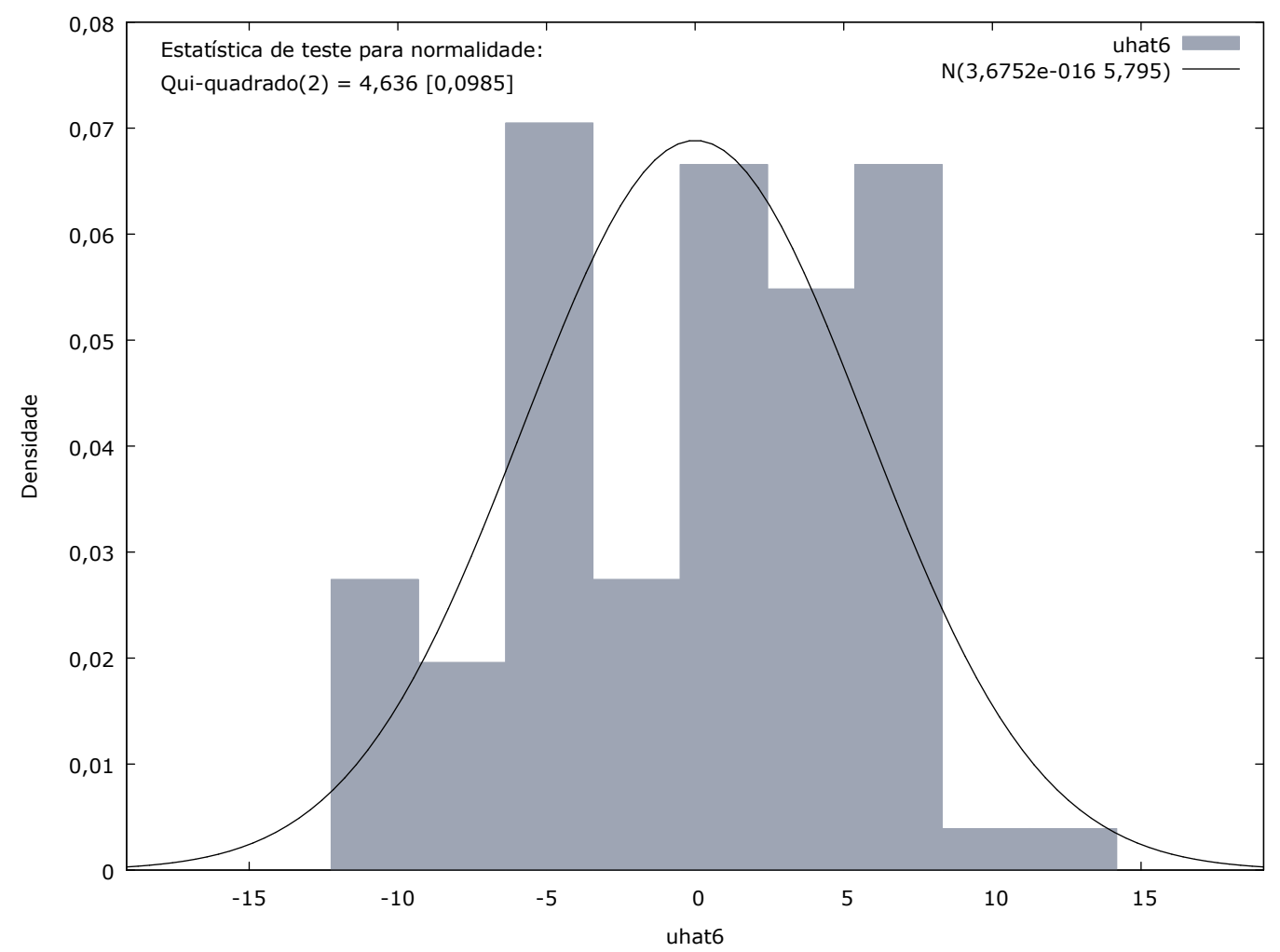

Distribuição de frequência para uhat6, observações 1-87

número de classes $=9$, média $=3,67522 e-016$, desvio padrão $=5,79503$

\begin{tabular}{|c|c|c|c|c|c|c|c|}
\hline \multicolumn{3}{|c|}{ intervalo } & pt. médio & \multicolumn{2}{|c|}{ frequência } & \multirow{2}{*}{$\begin{array}{l}\text { rel. } \\
\quad 8,05 \%\end{array}$} & \multirow{2}{*}{$\begin{array}{l}\text { acum. } \\
\star \star\end{array}$} \\
\hline & $<$ & $-9,3077$ & $-10,776$ & 7 & $8,05 \%$ & & \\
\hline$-9,3077$ & - & $-6,3720$ & $-7,8398$ & 5 & $5,75 \%$ & $13,79 \%$ & $\star *$ \\
\hline$-6,3720$ & - & $-3,4362$ & $-4,9041$ & 18 & $20,69 \%$ & $34,48 \%$ & 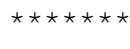 \\
\hline$-3,4362$ & - & $-0,50050$ & $-1,9684$ & 7 & $8,05 \%$ & $42,53 \%$ & $\star \star$ \\
\hline$-0,50050$ & - & 2,4352 & 0,96737 & 17 & $19,54 \%$ & $62,07 \%$ & 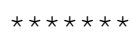 \\
\hline 2,4352 & - & 5,3710 & 3,9031 & 14 & $16,09 \%$ & $78,16 \%$ & 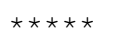 \\
\hline 5,3710 & - & 8,3067 & 6,8388 & 17 & $19,54 \%$ & $97,70 \%$ & 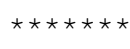 \\
\hline 8,3067 & - & 11,242 & 9,7746 & 1 & $1,15 \%$ & $98,85 \%$ & \\
\hline & $>=$ & 11,242 & 12,710 & 1 & $1,15 \%$ & $100,00 \%$ & \\
\hline
\end{tabular}

Teste para a hipótese nula de distribuição normal:

Qui-quadrado $(2)=4,636 \mathrm{com}$ p-valor 0,09846

Fatores de Inflacionamento da Variância (VIF)

Valor mínimo possível $=1,0$ 


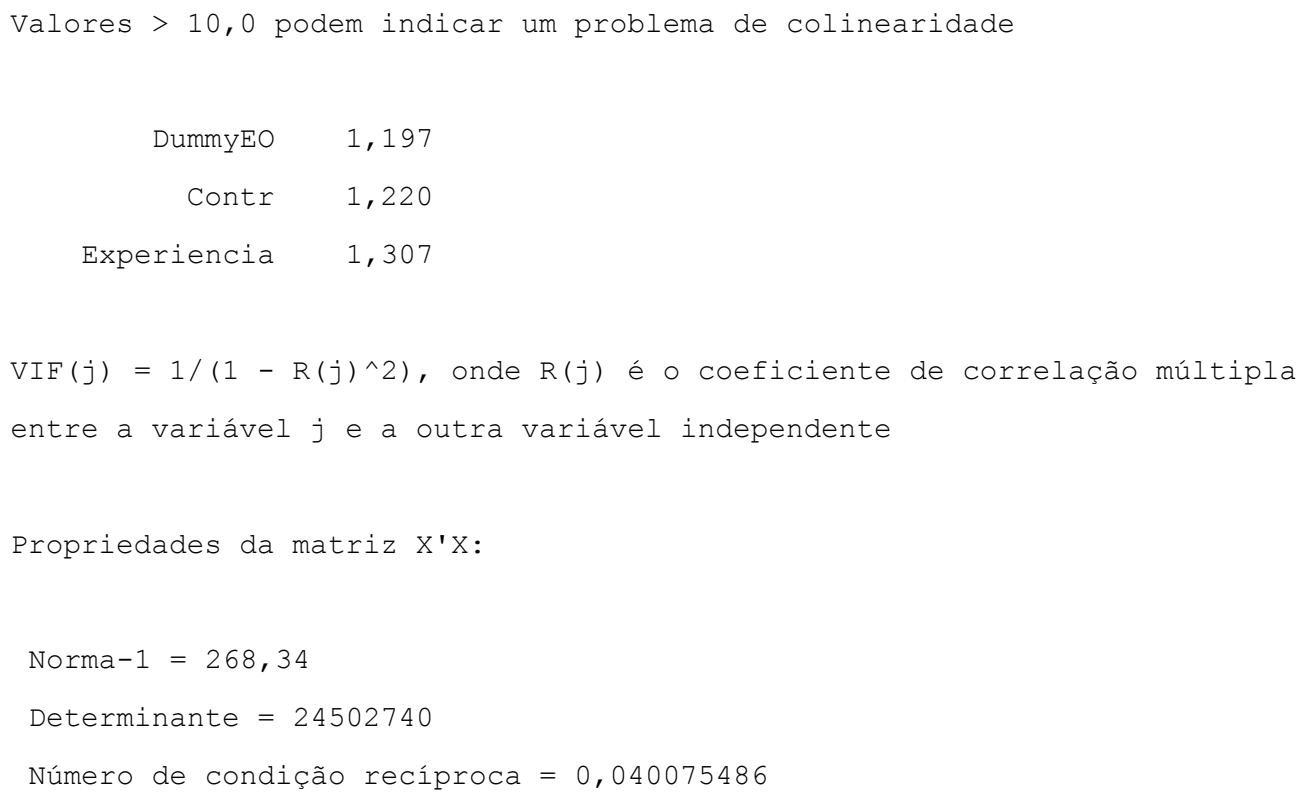

\section{Experimento 1}

Coeficientes de correlação, usando todas as observações 1 - 87 $5 \%$ valor crítico (bilateral $)=0,2108$ para $\mathrm{n}=87$

$\begin{array}{ccc}\text { ContrataI } & \text { ContrataII } & \\ 1,0000 & 0,4761 & \text { ContrataI } \\ & 1,0000 & \text { ContrataII }\end{array}$

Experimento 2

Coeficientes de correlação, usando todas as observações 1 - 87 $5 \%$ valor crítico $($ bilateral $)=0,2108$ para $\mathrm{n}=87$

$\begin{array}{lll}\text { InfoIII } & \text { InfoIV } & \\ 1,0000 & 0,2516 & \text { InfoIII } \\ & 1,0000 & \text { InfoIV }\end{array}$

Experimento 3

Coeficientes de correlação, usando todas as observações 1 - 87 $5 \%$ valor crítico $($ bilateral $)=0,2108$ para $\mathrm{n}=87$

$\begin{array}{lll}\text { FiscV } & \text { FiscVI } & \\ 1,0000 & 0,6517 & \text { FiscV } \\ & 1,0000 & \text { FiscVI }\end{array}$


Teste de Mann-Whitney do Experimento 1

\begin{tabular}{|c|c|c|c|}
\hline \multicolumn{4}{|c|}{ Grupo 1- Com presença de viés otimista } \\
\hline & Externo & Não Externo & \\
\hline Média & 13,938 & 13,778 & \\
\hline Desvio Padrão & 3,9911 & 4,2547 & \\
\hline Total Amostra & 16 & 27 & 43 \\
\hline \multicolumn{4}{|l|}{$\mathrm{z}$} \\
\hline \multirow[t]{2}{*}{ p-valor } & \multicolumn{3}{|l|}{0,6247} \\
\hline & Pedido & Não Pedido & \\
\hline Média & 14,313 & 13,556 & \\
\hline Desvio Padrão & 4,1428 & 4,1448 & \\
\hline Total Amostra & 16 & 27 & 43 \\
\hline \multicolumn{4}{|l|}{$\mathrm{Z}$} \\
\hline \multirow[t]{2}{*}{ p-valor } & \multicolumn{3}{|l|}{0,6199} \\
\hline & Empresa & Não Empresa & \\
\hline Média & 13 & 14,125 & \\
\hline Desvio Padrão & 4,4944 & 4,006 & \\
\hline Total Amostra & 11 & 32 & 43 \\
\hline \multicolumn{4}{|l|}{$\mathrm{z}$} \\
\hline p-valor & 0,2519 & & \\
\hline
\end{tabular}

Fonte: Dados da pesquisa (2015)

Teste de Mann-Whitney do Experimento 1

Grupo 2 - sem a presença de viés otimista

\begin{tabular}{l|l|l|l}
\hline & Externo & Não Externo & \\
\hline Média & 10,353 & 12,889 & \\
\hline Desvio Padrão & 4,7951 & 5,5285 & \\
\hline Total Amostra & 17 & 27 & 43 \\
\hline $\mathrm{z}$ & \multicolumn{3}{|l}{} \\
\hline p-valor & 0,0362 & Não Pedido & \\
\hline & Pedido & 11,25 & \\
\hline Média & 13,667 & 5,5416 & 44 \\
\hline Desvio Padrão & 4,5394 & 32 & \\
\hline Total Amostra & 12 & \multicolumn{2}{|l}{} \\
\hline$z$ & & \multicolumn{3}{|l}{} \\
\hline
\end{tabular}




\begin{tabular}{l|l|l|l}
\hline p-valor & 0,9234 & Não Empresa & \\
\hline & Empresa & 11,724 & \\
\hline Média & 12,267 & 4,8982 & \\
\hline Desvio Padrão & 6,2959 & 29 & 43 \\
\hline Total Amostra & 15 & \multicolumn{2}{l}{} \\
\hline z & \multicolumn{3}{|l}{} \\
\hline p-valor & 0,6949 & \\
\hline
\end{tabular}

Fonte: Dados da pesquisa (2015)

Teste de Mann-Whitney do Experimento 2

Grupo 1- Com presença de viés otimista

\begin{tabular}{|c|c|c|c|}
\hline & Auditoria & Não Auditoria & \\
\hline Média & 12,5 & 12,926 & \\
\hline Desvio Padrão & 3,1623 & 4,296 & \\
\hline Total Amostra & 16 & 27 & 43 \\
\hline \multicolumn{4}{|l|}{$\mathrm{Z}$} \\
\hline \multirow[t]{2}{*}{$\mathrm{p}$-valor } & \multicolumn{3}{|l|}{0,4479} \\
\hline & Jurídica & Não Jurídica & \\
\hline Média & 13,125 & 12,556 & \\
\hline Desvio Padrão & 4,5 & 3,5337 & \\
\hline Total Amostra & 16 & 27 & 43 \\
\hline \multicolumn{4}{|l|}{$\mathrm{Z}$} \\
\hline \multirow[t]{2}{*}{ p-valor } & \multicolumn{3}{|l|}{0,5125} \\
\hline & Administração & $\begin{array}{l}\text { Não } \\
\text { Administração }\end{array}$ & \\
\hline Média & 12,636 & 12,813 & \\
\hline Desvio Padrão & 4,1779 & 3,839 & \\
\hline Total Amostra & 11 & 32 & 44 \\
\hline \multicolumn{4}{|l|}{$\mathrm{z}$} \\
\hline p-valor & 0,5522 & & \\
\hline
\end{tabular}

Fonte: Dados da pesquisa (2015)

Teste de Mann-Whitney do Experimento 2

Grupo 2 - sem a presença de viés otimista

\begin{tabular}{l|l|l|l}
\hline & Auditoria & Não Auditoria & \\
\hline Média & 12,944 & 12,692 & \\
\hline Desvio Padrão & 4,1227 & 4,7478 & \\
\hline
\end{tabular}




\begin{tabular}{|c|c|c|c|}
\hline Total Amostra & 18 & 26 & 44 \\
\hline \multicolumn{4}{|l|}{ Z } \\
\hline \multirow[t]{2}{*}{ p-valor } & \multicolumn{3}{|l|}{0,4693} \\
\hline & Jurídica & Não Jurídica & \\
\hline Média & 11,091 & 13,364 & \\
\hline Desvio Padrão & 5,029 & 4,1745 & \\
\hline Total Amostra & 11 & 33 & 44 \\
\hline \multicolumn{4}{|l|}{$\mathrm{z}$} \\
\hline \multirow[t]{2}{*}{ p-valor } & \multicolumn{3}{|l|}{0,0869} \\
\hline & Inform. Adm. & Inform. Externas & \\
\hline Média & 13,867 & 12,241 & \\
\hline Desvio Padrão & 4,3238 & 4,4933 & \\
\hline Total Amostra & 15 & 29 & 43 \\
\hline \multicolumn{4}{|l|}{$\mathrm{z}$} \\
\hline p-valor & 0,9104 & & \\
\hline
\end{tabular}

Fonte: Dados da pesquisa (2015)

Teste de Mann-Whitney do Experimento 3

\section{Grupo 1- Com presença de viés otimista}

\begin{tabular}{l|l|l|l}
\hline & Suprim & Não Suprim & \\
\hline Média & 14,438 & 14 & \\
\hline Desvio Padrão & 3,8638 & 5,4065 & \\
\hline Total Amostra & 16 & 27 & 43 \\
\hline $\mathrm{z}$ & & & \\
\hline p-valor & 0,507428 & & \\
\hline & Externo & Não Externo & \\
\hline Média & 14,063 & 14,222 & \\
\hline Desvio Padrão & 4,7954 & 4,964 & 43 \\
\hline Total Amostra & 16 & 27 & 43 \\
\hline z & & 32 & \\
\hline p-valor & 0,561869 & & \\
\hline & Sem & Com Fiscalização & \\
\hline Total Amostra & 11 & & \\
\hline Desvio Padrão & 6,4413 & 14,25 & \\
\hline
\end{tabular}




\begin{tabular}{l|l|l|l}
\hline $\mathrm{z}$ & & & \\
\hline $\mathrm{p}$-valor & 0,4317 & & \\
\hline
\end{tabular}

Fonte: Dados da pesquisa (2015)

Teste de Mann-Whitney do Experimento 3

Grupo 2 - sem a presença de viés otimista

\begin{tabular}{l|l|l|l}
\hline & Suprim & Não Suprim & \\
\hline Média & 14,222 & 13,077 & \\
\hline Desvio Padrão & 5,3419 & 4,0192 & \\
\hline Total Amostra & 18 & 26 & 44 \\
\hline z & & & \\
\hline p-valor & 0,81866336 & & \\
\hline & Externo & Não Externo & \\
\hline Média & 12,455 & 13,909 & \\
\hline Desvio Padrão & 3,6156 & 4,8565 & 44 \\
\hline Total Amostra & 11 & 33 & \\
\hline z & & & \\
\hline p-valor & 0,1817 & & \\
\hline & Sem & Com Fiscalização & \\
\hline Total Amostra & 15 & 13,552 & \\
\hline Média & 13,533 & 4,7703 & \\
\hline Desvio Padrão & 4,3567 & 29 & \\
\hline Fonalor & 0,4633 & & \\
\hline
\end{tabular}

Fonte: Dados da pesquisa (2015) 


\section{D - Análise Complementar}

Testes transformando a variável Y em Ln

Modelo 01: MQO, usando as observações 1-87

Variável dependente: 1_Ativo

$\begin{array}{lccccc} & \text { Coeficiente } & \text { Erro Padrão } & \text { razão- } t & p \text {-valor } & \\ \text { DummyEO } & 3,07729 & 0,330586 & 9,3086 & <0,00001\end{array}$ ***

Média var. dependente

2,930399

D.P. var. dependente

0,358677

Soma resíd. quadrados

367,5465

E.P. da regressão

2,091783

R-quadrado

0,515208

R-quadrado ajustado

0,503666

$\mathrm{F}(3,84)$

29,75678

P-valor(F)

$3,33 \mathrm{e}-13$

Log da verossimilhança

$-186,1286$

Critério de Akaike

378,2572

Critério de Schwarz

385,6550

Critério Hannan-Quinn

381,2361

Modelo 02: MQO, usando as observações 1-87

Variável dependente: 1_Ativo

$\begin{array}{lccccl} & \text { Coeficiente } & \text { Erro Padrão } & \text { razão- } t & p \text {-valor } & \\ \text { DummyEO } & 2,96307 & 0,319475 & 9,2748 & <0,00001 & * * * \\ \text { Contr } & 0,467165 & 0,209479 & 2,2301 & 0,02837 & * *\end{array}$

Média var. dependente

2,930399

D.P. var. dependente

0,358677

Soma resíd. quadrados

374,7002

E.P. da regressão

2,099580

R-quadrado

0,505773

$\mathrm{F}(2,85)$

43,49283

R-quadrado ajustado

0,499958

Log da verossimilhança $\quad-186,9671$

P-valor(F)

9,81e-14

Critério de Schwarz

382,8661

Critério de Akaike

377,9343

Critério Hannan-Quinn

379,9202

Modelo 03: MQO, usando as observações 1-87

Variável dependente: 1_Passivo

$\begin{array}{lccccl} & \text { Coeficiente } & \text { Erro Padrão } & \text { razão- } t & p \text {-valor } & \\ \text { DummyEO } & 3,11982 & 0,322571 & 9,6717 & <0,00001 & * * * \\ \text { Contr } & 0,434195 & 0,219356 & 1,9794 & 0,05105 & * \\ \text { Experiencia } & 0,202224 & 0,170789 & 1,1841 & 0,23973 & \end{array}$

Média var. dependente

Soma resíd. quadrados

R-quadrado

$\mathrm{F}(3,84)$

Log da verossimilhança

Critério de Schwarz
2,928758

349,9392

0,537035

32,47979

$-183,9932$

381,3841
D.P. var. dependente

0,334327

E.P. da regressão

2,041064

R-quadrado ajustado

0,526012

P-valor(F)

4,90e-14

Critério de Akaike

373,9864

Critério Hannan-Quinn 
Modelo 04: MQO, usando as observações 1-87

Variável dependente: 1_Passivo

$\begin{array}{lccccc} & \text { Coeficiente } & \text { Erro Padrão } & \text { razão-t } & p \text {-valor } & \\ \text { DummyEO } & 3,01661 & 0,311304 & 9,6902 & <0,00001 & * * * \\ \text { Contr } & 0,530734 & 0,204122 & 2,6001 & 0,01099 & * *\end{array}$

Média var. dependente

Soma resíd. quadrados

R-quadrado

$\mathrm{F}(2,85)$

Log da verossimilhança

Critério de Schwarz
2,928758

355,7798

0,529308

47,79265

$-184,7132$

378,3583
D.P. var. dependente

0,334327

E.P. da regressão

2,045885

R-quadrado ajustado

0,523771

P-valor(F)

$1,23 \mathrm{e}-14$

Critério de Akaike

Critério Hannan-Quinn

MODELOS USANDO TERCIL

SEM A CONSTANTE E AS CARACTERÍSTICAS DO INDIVIDUO

Model 01: OLS, using observations 1-128 $(\mathrm{n}=49)$

Missing or incomplete observations dropped: 79

Dependent variable: EP

$\begin{array}{lccccl} & \text { Coefficient } & \text { Std. Error } & \text { t-ratio } & p \text {-value } & \\ \text { EO } & -2.90762 & 1.51394 & -1.9206 & 0.06176 & * \\ \text { ExtEO } & 10.9368 & 5.12547 & 2.1338 & 0.03889 & * * \\ \text { FMCont } & -5.35026 & 1.91958 & -2.7872 & 0.00802 & * * * \\ \text { Econt } & 10.8039 & 4.50237 & 2.3996 & 0.02104 & * * \\ \text { FMExp } & -3.22492 & 1.31752 & -2.4477 & 0.01875 & * * \\ \text { Eexp } & 11.8695 & 4.10046 & 2.8947 & 0.00606 & * * * \\ \text { A } & 2.49246 & 3.0341 & 0.8215 & 0.41612 & \\ \text { B } & 4.1309 & 3.50564 & 1.1784 & 0.24545 & \end{array}$

Mean dependent var

20.75510

S.D. dependent var

5.854239

Sum squared resid

2863.376

S.E. of regression

8.356940

R-squared

0.874154

Adjusted R-squared

0.852668

$\mathrm{F}(8,41)$

35.59935

Log-likelihood

P-value(F)

$4.55 \mathrm{e}-16$

$-169.1924$

Akaike criterion

354.3849

Schwarz criterion

369.5194

Hannan-Quinn

360.1269

Model 02: OLS, using observations 1-128 ( $\mathrm{n}=49)$

Missing or incomplete observations dropped: 79

Dependent variable: EP

$\begin{array}{lccccc} & \text { Coefficient } & \text { Std. Error } & t \text {-ratio } & p \text {-value } & \\ \text { EO } & -3.88701 & 1.26332 & -3.0768 & 0.00363 & * * * \\ \text { ExtEO } & 14.1936 & 4.30705 & 3.2954 & 0.00197 & * * * \\ \text { FMCont } & -5.10445 & 1.874 & -2.7238 & 0.00929 & * * *\end{array}$




$\begin{array}{lccccl}\text { Econt } & 10.2008 & 4.35571 & 2.3419 & 0.02388 & * * \\ \text { FMExp } & -3.25054 & 1.30228 & -2.4960 & 0.01647 & * * \\ \text { Eexp } & 13.076 & 3.93114 & 3.3263 & 0.00181 & * * *\end{array}$

Mean dependent var

Sum squared resid

$\mathrm{R}$-squared

$\mathrm{F}(6,43)$

Log-likelihood

Schwarz criterion
20.75510

2962.865

0.869781

47.86898

$-170.0292$

363.4094
S.D. dependent var

5.854239

S.E. of regression

Adjusted R-squared

8.300833

0.854640

P-value(F)

$1.87 \mathrm{e}-17$

Akaike criterion

352.0585

Hannan-Quinn

\section{SOMENTE COM AS VARIÁVEIS NUMÉRICAS DE EO, CONT E EXP (SEM DUMMIES) E SEM} A CONSTANTE E AS CARACTERÍSTICAS DO INDIVIDUOS

Model 03: OLS, using observations 1-43

Dependent variable: EP

$\begin{array}{lccccl} & \text { Coefficient } & \text { Std. Error } & \text { t-ratio } & p \text {-value } & \\ \text { EO } & 6.45388 & 0.989527 & 6.5222 & <0.00001 & * * * \\ \text { FMCont } & 2.75311 & 1.16442 & 2.3644 & 0.02313 & * * \\ \text { A } & 12.8396 & 2.21355 & 5.8004 & <0.00001 & * * * \\ \text { B } & 11.1439 & 2.31656 & 4.8106 & 0.00002 & * * *\end{array}$

Mean dependent var

Sum squared resid

R-squared

$\mathrm{F}(4,39)$

Log-likelihood

Schwarz criterion
19.95349

2362.064

0.871291

66.00239

$-147.1453$

309.3354
S.D. dependent var

S.E. of regression

Adjusted R-squared

P-value(F)

Akaike criterion

Hannan-Quinn
5.415821

7.782400

0.861391

$7.81 \mathrm{e}-17$

302.2906

304.8885

IDEM DO MODELO ACIMA

Model 04: OLS, using observations 1-43

Dependent variable: EA

$\begin{array}{lccccc} & \text { Coefficient } & \text { Std. Error } & t \text {-ratio } & p \text {-value } & \\ \text { EO } & 7.2022 & 1.01445 & 7.0996 & <0.00001 & * * * \\ \text { A } & 13.7379 & 2.22079 & 6.1860 & <0.00001 & * * * \\ \text { B } & 13.1725 & 2.31662 & 5.6861 & <0.00001 & * * *\end{array}$

Mean dependent var

Sum squared resid

R-squared

$\mathrm{F}(3,40)$

Log-likelihood

Schwarz criterion
20.81395

2554.177

0.872131

90.94031

$-148.8265$

308.9366
S.D. dependent var

S.E. of regression

Adjusted R-squared

P-value(F)

Akaike criterion

Hannan-Quinn
5.662137

7.990896

0.865738

$6.58 \mathrm{e}-18$

303.6530

305.6014 
Model 05: OLS, using observations 1-43

Dependent variable: EI

$\begin{array}{lccccc} & \text { Coefficient } & \text { Std. Error } & t \text {-ratio } & p \text {-value } & \\ \text { EO } & 2.32307 & 0.398471 & 5.8300 & <0.00001 & * * * \\ \text { A } & 4.77856 & 0.87232 & 5.4780 & <0.00001 & * * * \\ \text { B } & 4.37645 & 0.909959 & 4.8095 & 0.00002 & * * *\end{array}$

Mean dependent var

Sum squared resid

R-squared

$\mathrm{F}(3,40)$

Log-likelihood

Schwarz criterion
7.000000

394.0811

0.829476

64.85700

$-108.6445$

228.5726
S.D. dependent var

S.E. of regression

Adjusted R-squared

P-value(F)

Akaike criterion

Hannan-Quinn
2.203893

3.138794

0.820950

$2.03 \mathrm{e}-15$

223.2890

225.2375

Model 06: OLS, using observations 1-43

Dependent variable: EII

$\begin{array}{lccccc} & \text { Coefficient } & \text { Std. Error } & t \text {-ratio } & p \text {-value } & \\ \text { EO } & 2.31965 & 0.386661 & 5.9992 & <0.00001 & * * * \\ \text { A } & 4.71934 & 0.846466 & 5.5753 & <0.00001 & * * * \\ \text { B } & 4.56791 & 0.88299 & 5.1732 & <0.00001 & * * *\end{array}$

Mean dependent var

6.837209

S.D. dependent var

2.698591

Sum squared resid

371.0677

S.E. of regression

3.045766

0.839781

Adjusted R-squared

0.831770

$\mathrm{F}(3,40)$

69.88599

P-value(F)

$5.88 \mathrm{e}-16$

$-107.3508$

Akaike criterion

220.7016

Schwarz criterion

225.9852

Hannan-Quinn

222.6501

Model 07: OLS, using observations 1-43

Dependent variable: EIII

$\begin{array}{lccccl} & \text { Coefficient } & \text { Std. Error } & \text { t-ratio } & p \text {-value } & \\ \text { EO } & 1.73764 & 0.375148 & 4.6319 & 0.00004 & * * * \\ \text { A } & 4.00329 & 0.8392 & 4.7704 & 0.00003 & * * * \\ \text { B } & 3.27794 & 0.878253 & 3.7323 & 0.00060 & * * * \\ \text { FMCont } & 1.16131 & 0.441454 & 2.6306 & 0.01214 & * *\end{array}$

Mean dependent var

Sum squared resid

R-squared

$\mathrm{F}(4,39)$

Log-likelihood

Schwarz criterion
5.906977

339.5022

0.807538

40.90947

$-105.4394$

225.9236
S.D. dependent var

S.E. of regression

Adjusted R-squared

P-value(F)

Akaike criterion

Hannan-Quinn
2.505365

2.950455

0.792734

$1.86 \mathrm{e}-13$

218.8788

221.4767 
Model 08: OLS, using observations 1-43

Dependent variable: EIV

$\begin{array}{lccccc} & \text { Coefficient } & \text { Std. Error } & t \text {-ratio } & p \text {-value } & \\ \text { EO } & 2.27714 & 0.464147 & 4.9061 & 0.00002 & * * * \\ \text { A } & 4.13498 & 1.0161 & 4.0695 & 0.00022 & * * * \\ \text { B } & 4.61706 & 1.05994 & 4.3560 & 0.00009 & * * *\end{array}$

Mean dependent var

Sum squared resid

R-squared

$\mathrm{F}(3,40)$

Log-likelihood

Schwarz criterion
6.860465

534.6917

0.771010

44.89337

$-115.2049$

241.6934
S.D. dependent var

S.E. of regression

Adjusted R-squared

P-value(F)

Akaike criterion

Hannan-Quinn
2.721881

3.656131

0.759560

$7.14 \mathrm{e}-13$

236.4098

238.3582

Model 09: OLS, using observations 1-43

Dependent variable: EV

EO

A

B

FMCont

Mean dependent var

Sum squared resid

R-squared

$\mathrm{F}(4,39)$

Log-likelihood

Schwarz criterion

\section{Coefficient \\ 2.42045 \\ 4.28996 \\ 3.74862 \\ 1.01775}

Std. Error
0.407414
0.911377
0.953788
0.479421

t-ratio

5.9410

4.7071

3.9302

2.1229

7.046512
400.4125
0.834609
49.20109
-108.9872
233.0192

S.D. dependent var

S.E. of regression

Adjusted R-squared

P-value(F)

Akaike criterion

Hannan-Quinn

Model 10: OLS, using observations 1-43

Dependent variable: EVI

Coefficient

Std. Error

0.374836

0.8385

0.877521

3.5519

0.965222

0.441086

7.116279

338.9366

0.861997

60.90039

$-105.4035$

225.8519
S.D. dependent var

S.E. of regression

Adjusted R-squared

P-value(F)

Akaike criterion

Hannan-Quinn t-ratio

5.3585

4.0477 p-value

$<0.00001 \quad * * *$

$0.00003 \quad * * *$

$0.00034 * * *$

$0.04017 \quad * *$

2.609082

3.204214

0.821886

$9.96 \mathrm{e}-15$

225.9744

228.5723

Log-likelihood

Schwarz criterion

p-value

$<0.00001$

$<0.00001$

0.00024

0.03470

$* * *$

$* * *$

$* * *$

$* *$ 
TODA AMOSTRA

Model 11: OLS, using observations 1-128

Dependent variable: EI

$\begin{array}{lccccl} & \text { Coefficient } & \text { Std. Error } & \text { t-ratio } & p \text {-value } & \\ \text { A } & 6.21098 & 0.72721 & 8.5408 & <0.00001 & * * * \\ \text { B } & 7.07928 & 0.684463 & 10.3428 & <0.00001 & * * * \\ \text { FMExp } & -0.712614 & 0.279005 & -2.5541 & 0.01185 & * *\end{array}$

Mean dependent var

Sum squared resid

R-squared

$\mathrm{F}(3,125)$

Log-likelihood

Schwarz criterion
6.632812

2634.210

0.601179

62.80804

$-375.1799$

764.9158
S.D. dependent var

S.E. of regression

Adjusted R-squared

P-value(F)

Akaike criterion

Hannan-Quinn
2.768982

4.590608

0.594798

$7.82 \mathrm{e}-25$

756.3597

759.8361

Model 12: OLS, using observations 1-128

Dependent variable: EII
A
B
Mean dependent var
Sum squared resid
R-squared
$\mathrm{F}(2,126)$
Log-likelihood
Schwarz criterion

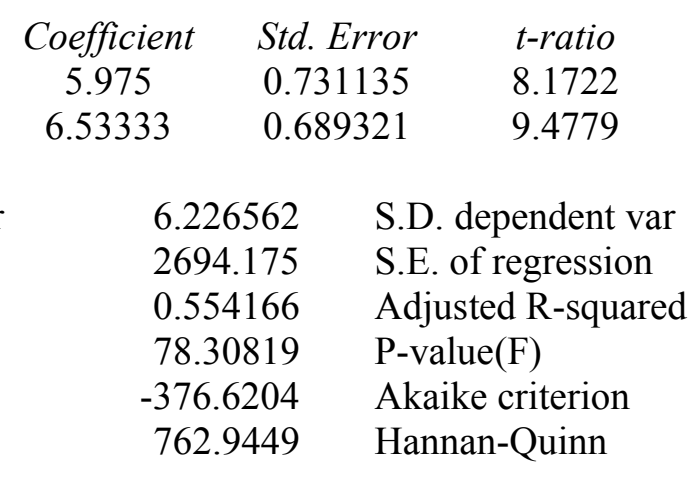

Model 13: OLS, using observations 1-128

Dependent variable: EIII

$\begin{array}{lccccl} & \text { Coefficient } & \text { Std. Error } & \text { t-ratio } & p \text {-value } & \\ \text { A } & 6.40113 & 0.708301 & 9.0373 & <0.00001 & * * * \\ \text { B } & 5.70938 & 0.668183 & 8.5446 & <0.00001 & * * * \\ \text { FMCont } & 0.782574 & 0.40924 & 1.9123 & 0.05815 & * \\ \text { FMExp } & -0.70761 & 0.282911 & -2.5012 & 0.01368 & * *\end{array}$

Mean dependent var

6.203125

S.D. dependent var

2.724515

Sum squared resid

2469.180

S.E. of regression

p-value

$<0.00001 \quad * * *$

$<0.00001 \quad * * *$

R-squared

0.579213

Adjusted R-squared

2.916731

4.624104

0.550628

$7.91 \mathrm{e}-23$

757.2408

759.5584
$\mathrm{F}(4,124)$

Log-likelihood

Schwarz criterion
42.67142

$-371.0392$

761.4866
P-value(F)

Akaike criterion

Hannan-Quinn
4.462370

0.569032

$1.82 \mathrm{e}-22$

750.0785

754.7137 
Model 14: OLS, using observations 1-128

Dependent variable: EIV

$\begin{array}{lccccl} & \text { Coefficient } & \text { Std. Error } & \text { t-ratio } & p \text {-value } & \\ \text { A } & 6.38746 & 0.782467 & 8.1632 & <0.00001 & * * * \\ \text { B } & 5.96008 & 0.736472 & 8.0927 & <0.00001 & * * * \\ \text { FMExp } & -0.547112 & 0.300205 & -1.8225 & 0.07077 & *\end{array}$

Mean dependent var

Sum squared resid

R-squared

$\mathrm{F}(3,125)$

Log-likelihood

Schwarz criterion
6.468750

3049.740

0.522882

45.66317

$-384.5541$

783.6644
S.D. dependent var

S.E. of regression

Adjusted R-squared

P-value(F)

Akaike criterion

Hannan-Quinn
2.855958

4.939425

0.515248

$5.36 \mathrm{e}-20$

775.1083

778.5847

Model 15: OLS, using observations 1-128

Dependent variable: EV

A
BMExp
FMCont

Mean dependent var

Sum squared resid

R-squared

$\mathrm{F}(4,124)$

Log-likelihood

Schwarz criterion

\section{Coefficient \\ 7.06329 \\ 7.31741 \\ $-0.740122$ \\ 0.881194}

t-ratio

9.6953

10.6472

$-2.5435$

2.0935

7.179688
2612.198
0.645708
56.49835
-374.6428
768.6938

S.D. dependent var

S.E. of regression

Adjusted R-squared

P-value(F)

Akaike criterion

Hannan-Quinn

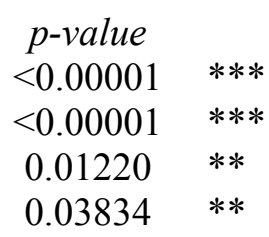

2.470084

4.589783

0.637136

$4.72 \mathrm{e}-27$

757.2856

761.9208

Model 16: OLS, using observations 1-128

Dependent variable: EVI
A
Mean dependent var
Sum squared resid
R-squared
$\mathrm{F}(2,126)$
Log-likelihood
Schwarz criterion
Coefficient
6.925
6.82222

Std. Error

0.740864

t-ratio

9.3472

0.698493

9.7671
p-value
$<0.00001$
$<0.00001$

2.750078

4.685636

0.588684

$3.00 \mathrm{e}-25$

760.6249

762.9425

6.742188

91.38270

$-378.3124$

766.3289
S.D. dependent var

Adjusted R-squared P-value(F)

Akaike criterion

Hannan-Quinn

Model 17: OLS, using observations 1-128

Dependent variable: EP

A

$\begin{array}{ccc}\text { Coefficient } & \text { Std. Error } & t \text {-ratio } \\ 19.6256 & 1.99902 & 9.8176\end{array}$

p-value $<0.00001 \quad * * *$ 
B

20.0374

1.8858

10.6254

$<0.00001 \quad * * *$

FMCont

2.12071

1.15499

1.8361

0.06873

0.00562

FMExp

$-2.25025$

0.798451

$-2.8183$

5.989472

Mean dependent var

20.01562

S.D. dependent var

12.59403

Sum squared resid

19667.59

S.E. of regression

0.639240

0.647762

Adjusted R-squared

$3.30 \mathrm{e}-27$

57.00857

P-value(F)

1015.689

Log-likelihood

Schwarz criterion

$-503.8447$

Akaike criterion

1020.325

Model 18: OLS, using observations 1-128

Dependent variable: EA

A
B

\section{Coefficient \\ 19.375}

$$
\text { Std. Error }
$$

t-ratio

2.05024

9.4501

p-value

19.2889

1.93299

9.9788

$<0.00001$

$<0.00001$

Mean dependent var

19.43750

S.D. dependent var

6.007541

Sum squared resid

21185.62

R-squared

0.599849

S.E. of regression

12.96687

$\mathrm{F}(2,126)$

94.44038

Adjusted R-squared

0.596673

$-508.6032$

P-value(F)

8.71e-26

Akaike criterion

1021.206

Schwarz criterion

1026.910

Hannan-Quinn

1023.524 
D - Proposta do Curso

\section{Normas Internacionais de Contabilidade para Empresas de Pequeno e Médio Porte LOCAL, TEMAS E HORÁRIOS DO TREINAMENTO.}

\section{Datas: Agosto, Setembro e Outubro de 2014;}

21 de março, 28 de março, 11 de abril e 18 de abril de 2015.

Local: Auditório do Setor V- CCSA/UFRN- Natal/RN

Horário: 08:00 às 12:00 h -Presencial e 04 horas de atividades à distância, totalizando 20 horas para cada curso.

Exposição de Motivos do Seminário: Este Seminário tem como objetivo incentivar os profissionais a participar de um experimento que faz parte da Tese em contabilidade da prof ${ }^{a}$ Adriana Isabel Backes Steppan, intitulada Uma análise da influência do viés de otimismo no julgamento de probabilidades de ativos e passivos contingentes e seu efeito na evidenciação contábil, do Programa Multi-Institucional e Inter-regional de pós-graduação em Ciências Contábeis, orientada pelo professor Dr. Cesar Augusto Tiburcio Silva. A intenção é oferecer o curso em troca da participação do experimento.

Objetivos do Seminário: Este Seminário tem como objetivo incentivar os profissionais, devidamente registrados no Conselho Regional de Contabilidade/RN, os quais necessitam da comprovação de horas complementares no Programa de Educação Continuada.

Conteúdo programático:

ESTOQUES, ATIVO IMOBILIZADO, ATIVOS INTANGÍVEIS, IRRECUPERABILIDADE DE ATIVOS.

1. Mensuração;

2. Custos de Estoque, Custos de Aquisição e Custos de Transformação;

3. Técnicas para avaliar o custo;

4. Ativo imobilizado e Intangíveis- Reconhecimento, Mensuração e Divulgação;

5. Irrecuperabilidade de Ativos

Número máximo de participantes: 80 participantes para cada curso

Frequência mínima: $100 \%$, ou seja, o profissional uma vez que aceita participar do experimento deverá comparecer nas 04 sessões previstas.

Critério de Avaliação: Participação ativa durante o transcorrer do curso. 